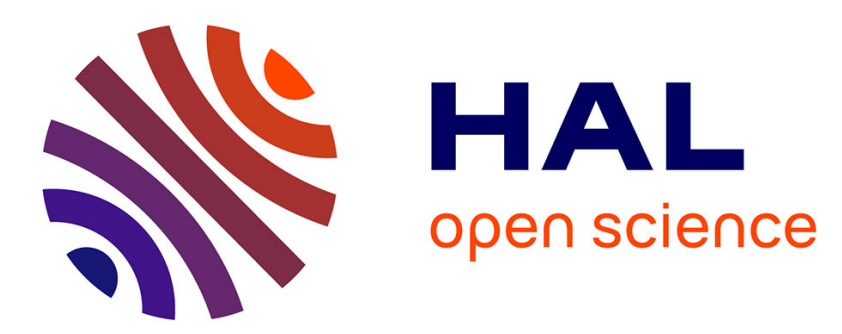

\title{
Fast cooling following a Late Triassic metamorphic and magmatic pulse: implications for the tectonic evolution of the Korean collision belt
}

Koen de Jong, Seokyoung Han, Gilles Ruffet

\section{To cite this version:}

Koen de Jong, Seokyoung Han, Gilles Ruffet. Fast cooling following a Late Triassic metamorphic and magmatic pulse: implications for the tectonic evolution of the Korean collision belt. Tectonophysics, 2015, Special issue on Comparative tectonic and dynamic analysis of cratons, orogens, basins, and metallogeny, 662, pp.271-290. 10.1016/j.tecto.2015.06.016 . insu-01169997

\section{HAL Id: insu-01169997 https://hal-insu.archives-ouvertes.fr/insu-01169997}

Submitted on 30 Jun 2015

HAL is a multi-disciplinary open access archive for the deposit and dissemination of scientific research documents, whether they are published or not. The documents may come from teaching and research institutions in France or abroad, or from public or private research centers.
L'archive ouverte pluridisciplinaire HAL, est destinée au dépôt et à la diffusion de documents scientifiques de niveau recherche, publiés ou non, émanant des établissements d'enseignement et de recherche français ou étrangers, des laboratoires publics ou privés. 
Fast cooling following a Late Triassic metamorphic and magmatic pulse and their bearing on the tectonic evolution of the Korean Collision Belt

Koen de Jong $1^{*}$, Seokyoung Han 1, Gilles Ruffet 2

1 School of Earth and Environmental Sciences, Seoul National University, 599

Gwnangno, Gwanak-gu, 151-747 Seoul, Republic of Korea

E-mail:keuntie@snu.ac.kr

Tel. +82 2-880-6632

Mob. +82 10-7357-1352

2 CNRS (CNRS/INSU) UMR 6118, Géosciences Rennes, 35042 Rennes Cedex, France and Université de Rennes I, Géosciences Rennes, 35042 Rennes Cedex, France 


\section{Abstract}

We discuss the evolution of Korea in the context of a relatively short-lived, tectonically induced, magmatic and metamorphic pulse that affected large portions of the crust of the peninsula's southern part during the Late Triassic. Recent ${ }^{40} \mathrm{Ar} /{ }^{39} \mathrm{Ar}$ single grain laser step-heating dates imply a prolonged metamorphic recrystallization between 243-220 Ma, which occurred in distinct phases that were not coeval throughout the peninsula. We obtained identical plateau ages between $231.4 \pm 0.8$ and $228.9 \pm 0.8 \mathrm{Ma}\left(1 \sigma ; 85-95 \%{ }^{39} \mathrm{Ar}\right.$ release $)$ on single grains of detrital muscovite from Jurassic sandstones (Gimpo Group). A literature review shows that the ages of detrital muscovites are identical to: (1) concordant ${ }^{40} \mathrm{Ar} /{ }^{39} \mathrm{Ar}$ ages of biotite (228 Ma) and amphibole (230 Ma) in amphibolites of the Deokjeongri Gneiss Formation and the Weolhyeonri Complex, pointing to very rapid cooling of $100-150^{\circ} \mathrm{C} / \mathrm{Ma}$, and (2) 231 229 Ma muscovite from the low-grade metamorphic mid-Paleozoic turbidites of the Taean Formation. The efficiency of cooling is further underlined by the nearcoincidence of these ${ }^{40} \mathrm{Ar} /{ }^{39} \mathrm{Ar}$ ages with 243-229 Ma (average: $234.6 \mathrm{Ma}$ ) zircon U$\mathrm{Pb}$ ages in the Gyeonggi Massif and the Hongseong belt, in the literature. It is argued that the Late Triassic magmatic and metamorphic pulse is superimposed on an earlier tectono-metamorphic event, possibly related to collision, indicated by: (1) 243-237 Ma muscovite ages, or age components in age spectra, (2) two generations of folds and associated tectonic foliations truncated by $\sim 229.5$-Ma-old syenites and earlier mafic dykes. The Late Triassic thermal pulse could have been the result of postcollisional delamination of the lower crust and uppermost mantle, and/or oceanic slab break-off, which is also suggested by almost coeval, widespread mantle-sourced Mg- 
rich potassic magmatism. Continuing ductile deformation is shown by mylonitization of Late Triassic magmatic rocks; a $\sim 220$ Ma muscovite age may be related to this.

\section{Keywords:}

Geochronology, ${ }^{40} \mathrm{Ar} /{ }^{39} \mathrm{Ar}$ laser probe, very fast cooling, Triassic, Korean Peninsula, thermal pulse 


\section{Introduction}

The Korean Peninsula forms part of an orogenic system where prolonged deformation, metamorphism and magmatism combined to create great complexity that has challenged geoscientists of different breed for several decades. Most studies on the geology of Korea are focused on the study of high-pressure metamorphic rocks (e.g., Ree et al., 1996; Lee and Cho, 2003; Oh et al., 2005; 2014; S.W. Kim et al., 2006b, 2011b; M. Cho et al., 2007; Kwon et al., 2009), litho-tectonic units (e.g., S.W. Kim et al., 2008; Oh et al., 2009; Oh, 2012; Chough et al., 2000, 2013) or more recently age distributions of detrital zircons (e.g., Jeon et al., 2007; Cho et al., 2010; S.W. Kim et al., 2014) and their correlations across the Yellow Sea to China and more specifically to the Qinling-Dabie-Sulu belt. Instead of such model-driven approaches, the goal of the present paper is rather to reconstruct geological processes, and to elucidate the tectonism responsible for them, ultimately aiming at placing the geological evolution in a geodynamic context. Isotope geochronology is instrumental in our effort, because every tectonic model should be based on well-constrained ages for different events.

Currently, the architecture and evolution of the Korean tectonic system are yet far from clear and timing of major events is not yet well constrained. Relatively commonly occurring isotopic ages between ca. 290 and 215 Ma in some of the tectonic terranes, show that the peninsula was affected by Permo-Triassic metamorphism and consequently by tectonism. The occurrence of amphibolite bodies with very rare relics of pervasively retrogressed mafic high-pressure granulite and eclogite (Oh et al., 2005; Kim et al., 2006; Zhai et al., 2007; Park et al., 2014b) suggests subduction to depths in the order of $60-75 \mathrm{~km}$. Yet, the age of subduction and collision is not well known as zircons from these rocks yielded U-Pb dates of 240 
\pm 5 and $231 \pm 3$ Ma (Guo et al., 2005; Kim et al., 2006; Park et al., 2014b). Many mountain belts that formed by crustal thickening were later in their tectonic evolution affected by horizontal crustal extension and associated lithospheric thinning and intruded by mantle-sourced Mg-rich potassic magmatic rocks (e.g., Liégeois and Black, 1987; Davies and von Blanckenburg, 1995; Turner et al., 1996; Gill et al., 2004; Duggen et al., 2005; Bianchini et al., 2008; Fowler et al., 2008; Dilek and Altunkaynak, 2009; Jiang et al., 2013; von Raumer et al., 2014). von Blanckenburg and Davies (1996) pointed out that associated late syn-collisional basaltic (lamprophyric, high-K calc-alkaline) and granitoid magmatism is the most valuable witnesses of slab break-off. A late Triassic gabbro-monzonite and syenite-granite suite with medium- and high-K calc-alkaline composition and shoshonitic affinity is also present in all major tectonic terranes of the Korean tectonic system (Fig. 1). Most plutons are between 233 and 224 Ma old, with only two bodies being older, viz., 237 and $240 \mathrm{Ma}$ (Oh et al., 2006b; Wu et al., 2007; Jeong et al., 2008; Peng et al., 2008; Choi et al., 2009; Williams et al., 2009; Seo et al., 2010; Kee, 2011; J.M. Kim et al., 2011; S.W. Kim et al., 2011a). 237-228 Ma mineral ages in (migmatitic) gneisses in large parts of central Korea imply a coeval regional metamorphic event. The Carnian to early Norian magmatic suite is usually interpreted as due to a change of tectonic regime subsequent to plate collision from compressional to tensional (Williams et al., 2009; Kim et al., 2011a), often linked to asthenospheric upwelling induced by lithospheric delamination (Choi et al., 2009), or oceanic slab break-off (Seo et al., 2010; Oh, 2012). Two alkali granites with A-type geochemistry yielded identical 219.3 \pm 3.3 Ma and 219.6 \pm 1.9 Ma U-Pb SHRIMP ages on zircon (Cho et al., 2008), which the authors interpreted as dating the extensional tectonism subsequent to major collision. 
The above overview shows that some of the currently available age estimates for the high-pressure metamorphism and the Late Triassic magmatism and associated regional high-temperature metamorphism that took place at low- to intermediatepressure are the same. However, the Late Triassic magmatism is often linked to delamination/slab detachment, which in tectonic models occurs significantly later than the high-pressure event. This underscores the difficulty linking $\mathrm{U}-\mathrm{Th}-\mathrm{Pb}$ age data of polygenetic accessory minerals to the evolution of assemblages of metamorphic minerals or to fabric-forming main phase silicates. In contrast to accessory mineral dating, ${ }^{40} \mathrm{Ar} /{ }^{39} \mathrm{Ar}$ dating is applied to rock-forming and fabricforming K-bearing minerals. This is a big advantage as their growth can be more straightforwardly correlated to major phases of the tectono-metamorphic evolution of rocks. In the present paper we report new high-quality ${ }^{40} \mathrm{Ar} /{ }^{39} \mathrm{Ar}$ age determinations between 231 and 229 Ma obtained from a number of detrital grains from metamorphic muscovite, some of which have a biotite core. We put these new dates into perspective with recently published isotopic ages in the ca. 243-220 Ma range obtained by ${ }^{40} \mathrm{Ar} /{ }^{39} \mathrm{Ar}$ laser-probe and Sensitive High-Resolution Ion Micro-Probe (SHRIMP) of metamorphic silicates and accessory minerals (e.g., de Jong and Ruffet, 2014a, b; de Jong et al., 2014; Han, 2014; S.W. Kim et al., 2014; Y. Kim et al., 2014; Oh et al., 2014; Park et al., 2014b) from different key areas along the northern and western margins of the Gyeonggi Massif (Figs. 2, 4, 7), combined with structural and other field data. Especially, information offered by low-grade metamorphic middle Paleozoic sediments (Taean Formation) on Anmyeon Island (Fig. 7), place important constraints on the tectonic evolution, as in contrast to the other key locations these rocks have only experienced early Mesozoic deformation and metamorphism. This approach helps to meet a major geochronological challenge of obtaining age estimates 
for the duration and speed of tectonic and metamorphic processes in the Korean orogenic system, and to constrain timing of different phases during the evolution information that is currently lacking. With this new information, pointing to very fast cooling in the late Triassic, we attempt to elucidate the meaning of the regional postcollisional magmatic-metamorphic pulse, and aim to put up a model for the tectonic evolution of the Korean Peninsula in during this period. We use the most recent international chronostratigraphic chart of the International Commission on Stratigraphy (Cohen et al., 2013; updated) to transfer isotopic dates to chronostratigraphical ages.

\section{Regional Geology}

Much of Korea consists of Precambrian continental crust formed from material extracted from the mantle in the late Neoarchean, subsequently strongly affected by Paleoproterozoic high-grade metamorphism and magmatism, peaking in the 1.93-1.83 Ga period (Lee and Cho, 2012). The Precambrian basement is subdivided into three gneiss terranes, viz. the Nangrim, Gyeonggi and Yeongnam Massifs, from North to South (Fig. 1). Of these three, only the Gyeonggi Massif has been seriously affected by Triassic metamorphism, as recorded in isotopic ages of Ubearing accessory minerals in the 250-215 Ma range, but mostly between 235 and 231 Ma (D.L. Cho et al., 1996; Oh et al., 2006b, 2015; S.W. Kim et al., 2006, 2008; J.M. Kim et al., 2008; K.H. Kim et al., 2008; Kim et al., 2009; Suzuki, 2009; Yi and Cho, 2009; Kee, 2011; Cho et al., 2013b; Lee et al., 2014; Yengkhom et al., 2014). The three Precambrian terranes are separated by two belts of multiple-deformed and metamorphosed sedimentary and volcanic rocks of late Neoproterozoic to middle and 
late Paleozoic age: the Imjingang and Ogcheon Belts (Fig. 1; e.g., Kim, 1998; Chough et al., 2000; Lim et al., 2005; M. Cho et al., 2007, 2013a; Kee, 2011; Choi et al., 2012). Multiply deformed greenschist facies metamorphic middle Paleozoic turbidites (Figs. 1, 7; Taean Formation), which are comparable to similar series in the Imjingang Belt and part of the southwestern Ogcheon Belt (Choi et al., 2008; Kee, 2011; So et al., 2013; Cho et al., 2013a; S.W. Kim et al., 2014), crop out discontinuously along the western margin, and structurally uppermost part, of the Gyeonggi Massif (Fig. 1). These middle Paleozoic meta-sedimentary terranes, draped around the Gyeonggi Massif, have been variously deformed and metamorphosed starting from the latest Paleozoic to early Mesozoic (D.L. Cho et al., 1996, 2005; Cheong et al., 2003; Oh et al., 2004; Kim, 2005; Kim et al., 2007; Kee, 2011; de Jong and Ruffet, 2014a, b; de Jong et al., 2014; Han, 2014; S.W. Kim et al., 2014). Paleozoic meta-sedimentary rocks surrounded by gneisses also occur as small isolated outcrops in the eastern part of the Gyeonggi Massif (Kee, 2011; S.W. Kim et al., 2014). The pressure and temperature conditions in rocks of these meta-sedimentary terranes indicate that metamorphism and deformation occurred at maximum depths in the order of 20-35 $\mathrm{km}$, which would agree with a collisional setting. All terranes affected by Triassic metamorphism have been regarded as major tectonic boundaries, or suture zones, and thus considered as possible eastward extension of the Late Paleozoic - Early Mesozoic Qinling-Dabie-Sulu ultrahigh-pressure metamorphic belt in often sharply conflicting models (Ernst et al., 1988; Cluzel et al., 1990; Yin and Nie, 1993; Ree et al., 1996; Chough et al., 2000, 2013; Lee and Cho, 2003; Oh et al., 2005, 2006a, 2009; S.W. Kim et al., 2006b, 2008, 2011b; M. Cho et al., 2007, 2013a; Zhai et al., 2007; Kwon et al., 2009; Oh, 2012; Choi et al., 2012; Lee et al., 2014; Yengkhom et al., 2014; S.W. Kim et al., 2014). 
Although most of the $\mathrm{U}-\mathrm{Th}-\mathrm{Pb}$ age data of polygenetic accessory minerals fall in the 235-231 Ma range, researchers found a number of older isotopic dates for such minerals between 245 and $260 \mathrm{Ma}$ (errors: 3-16 Ma) in the Gyeonggi Massif (Suzuki, 2009; Lee et al., 2014; Yengkhom et al., 2014) and the Imjingang Belt and correlatives (D.L. Cho et al., 1996, 2005; Kim et al., 2014). The Ogcheon Metamorphic Belt too has yielded older isotopic ages in the 275-290 Ma range (errors: 10-15\%) (Cheong et al., 2003; Oh et al., 2004; Kim, 2005; Kim et al., 2007). But there are no indications that these Permian to earliest Triassic dates refer to the high-pressure metamorphism. Zircons from the relict eclogite and mafic high-pressure granulite (Bibong and Baekdong bodies) that occur associated with strongly serpentinized ultramafic rocks in the Hongseong area along the Gyeonggi Massif's western margin (Figs. 1, 4) have yielded U-Pb dates of $240 \pm 5$ and $231 \pm 3 \mathrm{Ma}$ (Guo et al., 2005; Kim et al., 2006; Park et al., 2014b). The petrology of these strongly retrogressed bodies suggests subduction to depths in the order of $60-75 \mathrm{~km}$, but their tectonic position and age is controversial. Kim et al. (2011b, c, 2014), Kwon et al. (2013) and Park et al. (2014) refer to this area as the Hongseong suture zone, although it is not clear which plates collided. They envisaged that this zone was the site of sedimentation, volcanism and plutonism in a "Pacific-type" arc-trench system due to prolonged subduction followed by "Alpine-type" plate collision in terminal Paleozoic to earliest Mesozoic time. However, the exact tectonic meaning of this mélange-like rock distribution in the Hongseong area is unclear due to very poor outcrop conditions, low relief and intense superimposed (Jurassic and younger) deformation, in the form of faults and thrusts (Fig. 4).

All major tectonic terranes were intruded by late Triassic and Early to Middle Jurassic plutonic rocks (Fig. 1). The Triassic gabbro-monzonite and syenite-granite 
suite forms relatively small, compositionally zoned, isolated plutons, forming about $10 \%$ of the granitoids in Korea. In contrast, the Jurassic intrusions making up $65 \%$ (Sagong et al., 2005; Park et al., 2010), form complex linear chains of coalesced giant Cordilleran-type batholiths, generated during 50 to 60 million years of subduction of Pacific oceanic lithosphere below the East Asian continental margin (Maruyama et al., 1997). This underscores that both magmatic episodes occurred in strikingly different geodynamic settings, also reflected by chemical differences (J.M. Kim et al., 2011).

Late Triassic (?) to Middle Jurassic non-marine sedimentary succession of the Daedong Supergroup, occurring as relatively small isolated fault-bounded outcrops, is regarded to have been deposited in a foreland basin or an intra-arc setting (Egawa and Lee, 2008, 2009). U-Pb zircon geochronology implies that sedimentation principally took place in the late Early to earliest Middle Jurassic (ca. 187-172 Ma; Han et al., 2006; Jeon et al., 2007). The most prominent peak in age probability diagrams for detrital zircons corresponds to the Paleoproterozoic age range found in the Gyeonggi Massif; other prominent peaks are of Early Permian, Middle-Late Triassic, and EarlyMiddle Jurassic age, in addition there are very subordinate Archean, Neoproterozoic and middle Paleozoic peaks (Jeon et al., 2007). This suggests that most preCretaceous rock types currently cropping out were already at erosion level by mid Jurassic time, or being recycled. Subsequent significant deformation (Daebo tectonic phase: e.g., Chang, 1997; Kim 1998; Chough et al., 2000) strongly fragmented the outcrop pattern of most Korean rocks, severely hampering a complete reconstruction of the early Mesozoic collisional architecture of the Korean Peninsula. 


\section{Gyeonggi Massif and rocks along its western and northern margins}

\subsection{Gyeonggi Massif}

The Gyeonggi Massif (Fig. 1) is a poly-metamorphic terrane that mainly comprises middle Paleoproterozoic (ca. 1.93-1.83 Ga) high-grade gneiss (e.g., Kee, 2008; Lee and Cho, 2012; Lee et al., 2014; Oh et al., 2015) with minor Neoproterozoic (0.9-0.75 Ga) magmatic and sedimentary material along its western and northern margins (Lee et al., 2003; J.M. Kim et al., 2008; Oh et al., 2009; Park et al., 2014b). The Paleoproterozoic rocks experienced two superimposed tectonometamorphic cycles: M1 under lower granulite-facies to upper amphibolite-facies conditions of middle Paleoproterozoic age and a second, weaker one (M2) that is characterized by decompression with or without reheating (e.g., Y. Cho et al., 1996; Lee and Cho, 2003; Oh et al., 2006a, 2015; Cho et al., 2013b; Lee et al., 2014; Yengkhom et al., 2014). Metamorphism during the M2 event (0.5-0.35 GPa, 650$750^{\circ} \mathrm{C}$; Cho et al., 2013b; Lee et al., 2014; Oh et al., 2015) gave rise to moderate but widespread anatexis. Zircon from a cordierite-rich migmatite near a Triassic intrusion yielded a ca. $235 \mathrm{Ma}$ U-Pb SHRIMP age (Oh et al., 2015). A leucosome formed by tourmaline-bearing granite gneiss that occurs in migmatitic biotite gneiss of the central Gyeonggi Massif yielded monazite with a $232.5 \pm 1.4 \mathrm{Ma}$ U-Pb SHRIMP age (Kee, 2008), which would date this regional metamorphism. Locally far more extreme metamorphic conditions $\left(\mathrm{T}=>900^{\circ} \mathrm{C}, \mathrm{P}=0.75 \mathrm{GPa}\right)$ are recorded by rare granulites containing hercynitic low- $\mathrm{Zn}$ spinel $(\mathrm{ZnO}=1.6-2.6)$ in the eastern Gyeonggi Massif (Oh et al., 2006a, Odesan area, Fig. 1). Upper amphibolite and granulite facies conditions frequently result in the formation of metamorphic rims around older zircon 
crystals likely due to the release of zirconium from mineral phases that became unstable (Williams, 2001; Parrish and Noble, 2003). Therefore, zircon rims that yielded SHRIMP U-Pb ages of 237-235 Ma (errors ca. 2\%) in the Gyeonggi Massif also show that M2 probably is a Late Triassic metamorphic overprint. The Odesan spinel granulites occur $<2 \mathrm{~km}$ from hypersthene-bearing monzonite pluton (Oh et al., 2006a), zircons of which yielded a $229 \pm 1 \mathrm{Ma} \mathrm{U}-\mathrm{Pb}$ age (Jeong et al., 2008).

\subsection{Northern Margin Gyeonggi Massif - Juksung Area}

The Juksung area (Fig. 2) is formed by the strongly retrogressed and ductilely deformed upper part of the northern Gyeonggi Massif. The rocks typically comprise quartz-biotite-muscovite-chlorite schists with up to 30-50 m thick series of wellfoliated micaceous, occasionally garnet-bearing, quartzite, with some layers of finegrained, sometimes garnet-bearing, amphibolite. The Juksung area is located between the Imjingang belt (North) and Neoproterozoic alkaline meta-granitoids with a compositional range from syenite to alkali granite, which yielded an ion microprobe U-Pb zircon age of $742 \pm 13 \mathrm{Ma}$ (Lee et al., 2003) (South). The latter are variably deformed, strongly retrogressed and transformed into muscovite-bearing augen gneisses and (ultra)mylonites in the Gyeonggi shear zone (Fig. 2; Kim et al., 2000). These authors obtained a Rb-Sr age of $226 \pm 1$ Ma on newly formed muscovite from a mylonite from this ductile shear zone, which is among the youngest isotopic ages obtained on gneisses of the Gyeonggi Massif. Laser probe step-heating by de Jong and Ruffet (2014b) of muscovite single grains from the strongly retrogressed and ductilely deformed rocks in this area resulted in ${ }^{40} \mathrm{Ar} /{ }^{39} \mathrm{Ar}$ (pseudo)plateau ages (1бof: $242.8 \pm 1.0 \mathrm{Ma}$ (mica schist) and $219.7 \pm 0.9 \mathrm{Ma}$ (mylonitic quartzite) (Fig. 3a), as 
well as a plateau age of $240.3 \pm 1.0 \mathrm{Ma}$ from a chlorite-muscovite-biotite schist (Fig. 3b). A second muscovite grain from this rock, with a sizeable core of biotite has step ages that are concordant or only slightly younger during the main $90 \%$ of the ${ }^{39} \mathrm{Ar}$ release (Fig. 3b). The combined age steps define a sharp 239.1 Ma age peak in a relative frequency diagram.

Rocks of the Gimpo Group, forming the northernmost outcrops of the Daedong Supergroup in South Korea, crop out to the north of the Gyeonggi Shear Zone (Fig. 2). These are dull dark grey to black shales that contain lenses of thickbedded medium to coarse-grained rarely cross-bedded sandstones with isolated pebbles and matrix supported conglomerates with angular to sub-rounded and randomly oriented quartz, and dark chert-like pebbles. Some conglomerate levels have large K-Fsp pebbles, similar to the K-Fsp crystals present in the underlying Gyeonggi Massif. Both upward fining and upward coarsening series are present. We sampled coarse-grained sandstone for ${ }^{40} \mathrm{Ar} /{ }^{39} \mathrm{Ar}$ dating of single detrital muscovite grains (JK52, 53 and 56; Fig. 2). Locally, pelitic rocks contain a cleavage oblique to bedding that is axial planar to large-scale tight (southward overturned) folds. Pelites in the lowermost parts of the group are shiny phyllites with a well-developed bedding parallel tectonic foliation and lineation, whereas psammites at this level are quartzitic. These metasediments contain brittle-ductile deformation structures.

\subsection{Western Margin Gyeonggi Massif - Hongseong Area and Anmyeon Island}

A unique suite of rocks crops out along the Gyeonggi massif's western margin in the Hongseong area (Figs. 4) and on Anmyeon Island (Fig. 7). These are: the Deokjeongri Gneiss Formation and the Weolhyeonri Complex that include many lenses of mafic- 
ultramafic rocks of Neoproterozoic to Mesozoic age (Oh et al., 2005, 2009, 2014; S.W. Kim et al., 2006, 2008, 2011c, 2014) (Hongseong area), the middle Paleozoic meta-turbidite sequence of the Taean Formation, and finally the Paleoproterozoic to Mesoproterozoic (Kee, 2011), metasedimentary rocks of the Gonam Complex, which may be as young as Triassic (Kim et al., 2014) and exclusively cropping out at the southern tip of Anmyeon Island (Fig. 7). Late Triassic post-collisional magmatic activity is manifest by Haemi pluton (230-234 Ma; Choi et al., 2009; Seo et al., 2010;

Cheong et al., 2014) in the Hongseong area (Fig. 4), and the Mongsanpo intrusion (229.6 \pm 3.5 Ma; Han, 2014) on Anmyeon Island (Fig. 7).

\subsubsection{Weolhyeonri Complex and Deokjeongri Gneiss Formation}

The definitions of the Weolhyeonri Complex and the Deokjeongri Gneiss Formation defined on the one hand by e.g., Kim et al. (2011), Choi et al. (2012), Kim et al. (2013), and Park et al. (2014), and on the other by Oh et al. (2005), Kim et al. (2006, 2008), and Kee (2011) are different. The first group of authors incorporated the western part of the Deokjeongri Gneiss Formation into the Weolhyeonri complex based on the finding of ca. 437-370 Ma SHRIMP U-Pb ages for zircons from arcrelated metavolcanic and metamorphic rocks. They, thus, consider the Weolhyeonri complex as a middle Paleozoic subduction accretion complex. In contrast, in earlier publications Kim et al. (2006, 2008) and Oh et al. (2005) regard the Weolhyeonri complex as essentially Neoproterozoic on the basis of a widespread 850-750 Ma tonalite-trondhjemite-granodiorite and alkaline magmatic rocks, which were subsequently metamorphosed during the middle Paleozoic. 
The distribution of lithologies of different age and provenance in the Hongseong area has a distinct lens-shaped aspect, bolstered by the pattern of maficultramafic rocks (Fig. 4). One outcrop that was sampled for ${ }^{40} \mathrm{Ar} /{ }^{39} \mathrm{Ar}$ forms as a large lens of the Weolhyeonri Complex in the Deokjeongri Gneiss Formation (Fig. 4), which undoubtedly point to importance of tectonic processes. Kim et al. (2011b, c, 2014) incorporated the eastern part of the Deokjeongri Gneiss Formation into the Weolhyeonri Complex because of a significant population of 850-750 Ma-aged detrital zircons present in alleged middle Paleozoic metasediments that they regarded as derived from the adjacent Deokjeongri rocks. In addition to this broad and low peak of Neoproterozoic ages, this relative frequency diagram contains a sharp main peak of Early Paleozoic ages (average/mean peak: 420 Ma) (Kim et al. 2014). Striking is the virtual absence of Precambrian zircons; there are no ages corresponding to the age range of the Gyeonggi Massif. For this reason we do not regard the Weolhyeonri Complex as part of the Gyeonggi Massif, but as an independent tectono-sedimentary unit, tectonically emplaced adjacent to it, and metamorphosed in the Late Triassic. The occurrence of mafic-ultramafic rocks, partly associated with retrogressed eclogite would fit in a mélange type setting.

The Weolhyeonri Complex (Fig. 4) comprises both Neoproterozoic gneisses and Middle Paleozoic intermediate- to high-grade metamorphic sediments, including marble, as well as metabasites, felsic rocks and lens-shaped bodies of highly serpentinized ultramafic rocks (Kim and Kee, 2010; Kim et al., 2011b, c; Kwon et al., 2013). These authors regard this volcano-sedimentary series as having formed in an arc - fore-arc setting during the Silurian and Devonian (ca. 437-370 Ma). Metamorphic overgrowth in zircon rims with ages of 427-400 Ma point to Late Silurian to Early Devonian metamorphism (Kim et al., 2011b; Park et al., 2014a). 
Geothermo-barometry of rare garnet amphibolite, quartz garnetite, marble and hornblende gneiss that occur surrounded by strongly deformed tonalitic and granodioritic gneiss of the Deokjeongri Gneiss Formation (Fig. 4) point to metamorphic conditions in the range of 1.0-1.4 GPa and $700-800^{\circ} \mathrm{C}(\mathrm{Kee}, 2008)$, and 0.8-1.4 GPa and 550-740 ${ }^{\circ} \mathrm{C}$ (Kwon et al., 2013). Hornblende-plagioclase symplectites around the garnet porphyroblasts indicate decompression of these rocks. The Deokjeongri Gneiss Formation (Fig. 4) originated from a tonalitetrondhjemite-granodiorite suite intruded in a Neoproterozoic (ca. 750-850 Ma) arc (Oh et al., 2005; S.W. Kim et al., 2006, 2008; Kee, 2011) that was strongly deformed and migmatized. Anatexis was localized in shear zones that deflect the main foliation, and also occurred in irregular veins and patches along the main foliation (Fig. 5a). Irregular veins of fine-grained essentially non-deformed leuco-granitic rocks cut the shear zones, the main foliation, and earlier partial melt zones (Fig. 5a). This process probably took place in part during the Triassic, as suggested by isotopic ages, see below.

Some of the strongly retrogressed (ultra)mafic lenses formed in Neoproterozoic and middle Paleozoic times in different tectonic settings, and contain relics of high-pressure metamorphism with a strikingly different timing, viz., Devonian and (?)Triassic (Kwon et al., 2013; Oh et al., 2014; Park et al., 2014). The 803-806 Ma (errors 1.5-3\%; Kim et al., 2006; Park et al., 2014) mafic intrusive rocks of the Bibong body (Fig. 4) underwent eclogite facies metamorphism (1.65-2.1 GPa, $775-850^{\circ} \mathrm{C}$ ) followed by near-isothermal decompression to $1.1-1.6 \mathrm{GPa}$ to granulitefacies conditions, and a final phase of amphibolite-facies metamorphism (0.8-0.9 $\left.\mathrm{GPa}, 550-735^{\circ} \mathrm{C}\right)(\mathrm{Oh}$ et al., 2005; Kim et al., 2006). On the one hand, based on mapping Park et al. (2014) claimed that these mafic rocks originally intruded 
Paleoproterozoic gneisses in Neoproterozoic time. These gneisses could, hence, form part of the westernmost limit of the Gyeonggi Massif, suggesting that at least this part was affected by deep subduction. On the other hand, other studies concluded that this metabasite body and Paleoproterozoic rocks were in fault contact (e.g. Oh et al., 2005, 2014). In addition, these authors pointed out that their island arc geochemical character would not fit into a continental arc setting. This interpretation would imply that only rocks along the Gyeoggi Massif's southwestern margin, viz. the Deokjeongri Gneiss Formation and the Weolhyeonri Complex were affected by subduction-related metamorphism, but not the massif itself.

Rocks in the Hongseong area, including those with eclogitic relics, display widespread Triassic U-Pb zircon ages, often in rims, between $243 \pm 6$ and $229 \pm 10$ Ma (Fig. 4), averaging 234.6 Ma (N=22) (Guo et al., 2005; S.W. Kim et al., 2006, 2008, 2011a, b; Kee, 2011; Kwon et al., 2013; Park et al., 2014). Two amphibolites (Fig. 6) yielded concordant single grain ${ }^{40} \mathrm{Ar} /{ }^{39} \mathrm{Ar}$ laser probe step-heating (pseudo-) plateau age (1ø̣of 228.1 $\pm 1.0 \mathrm{Ma}$ (biotite), $230.1 \pm 1.0 \mathrm{Ma}$ (hornblende) from the Deokjeongri Gneiss Formation and 229.8 $\pm 1.0 \mathrm{Ma}$ (hornblende) the Weolhyeonri Complex (de Jong and Ruffet, 2014a). The latter hornblende age is nearly concordant with a $234 \pm 2 \mathrm{Ma} \mathrm{U}-\mathrm{Pb}$ age of a zircon rim in the Neoproterozoic Sinri garnetite (Kwon et al., 2013) from the same outcrop. The combined age steps define a sharp 229.1 Ma age peak in a relative frequency diagram (Fig. 6). These plateau ages are identical to a $231 \pm 6 \mathrm{Ma}\left(2 \sigma \underline{\mathrm{h}} \mathrm{hornblende}{ }^{40} \mathrm{Ar} /{ }^{39} \mathrm{Ar}\right.$ plateau age (Kee, 2008), and essentially concordant with $\mathrm{U}-\mathrm{Pb}$ ages of $234 \pm 2$ and $235 \pm 8$ Ma from rims of zircon in nearby tonalitic gneisses (Kee, 2011).

The Gonam complex (Fig. 7) comprises a highly heterogeneous assemblage of gneisses, metasediments, with lenses of mafic and ultramafic rocks. Highly striking is 
the association of dark-grey to black metapelites, strongly folded marble with deformed lenses of mafic-ultramafic rocks (Fig. 5b) that occur jointly with rare finegrained brick red siliceous layers/fine quartzites (Fig. 5c). This association resembles part of an ocean plate stratigraphy, which may suggest that the Gonam Complex is part of a subduction-accretion complex, albeit of unknown age.

\subsubsection{Taean Formation on Anmyeon Island}

The Taean Formation on Anmyeon Island, located about $50 \mathrm{~km}$ to the west of the Hongseong area (Fig. 7), comprises rhythmically layered and graded-bedded series of light-coloured sandstone and dark gray pelite with intercalations of calcareous psammite and minor carbonate, as well as rare thin black very-fine-grained tuff horizons. These rocks were probably originally deposited by deep-water turbidites in a submarine distal fan/lobe environment (Lim et al., 1999; Choi et al., 2008; So et al., 2013). The youngest Paleozoic peaks of concordant SHRIMP U-Pb spot ages in rims of detrital zircon are between 431 and $420 \mathrm{Ma}$ (errors $~ 1 \%$ ), implying their deposition after the late Silurian (Cho, 2007; Cho et al., 2010; Kee, 2011; Na et al., 2012; So et al., 2013; Han, 2014; Kim et al., 2014). A compilation by Kim et al. (2014) shows that meta-sandstones of the Yeoncheon Group (Imjingang Belt), the Weolhyeonri Complex and the southwestern Ogcheon Metamorphic Belt have similar zircon age distributions. The rhythmic intercalation of quartzites of the Yeoncheon Group, occasionally containing multiple sets of graded bedding, with metapelites is indicative of a turbidite sequence (Kee, 2008; Han, 2014), like the Taean Formation.

The metasediments of the Taean Formation are affected by two phases of superimposed deformation. The earliest cleavage $S_{1}$ in meta-pelites generally is a 
well-developed bedding-parallel quartz-mica differentiation foliation, and only locally axial planar to rare recumbent isoclinal folds (Fig. 8a). But in meta-sandstone and calc-silicate rocks shape fabric development is generally minor. $\mathrm{F}_{2}$ folds are megascopic open to tight disharmonic flexural slip structures (Fig. 8b), which in meta-pelites may have a well-developed crenulation cleavage $S_{2}$ as axial plane foliation. Mesoscopic $F_{2}$ folds and their axial plane cleavage $S_{2}$ are truncated by mafic dykes (Fig. 8c).

De Jong et al. (2014) argued that metamorphism of meta-pelites (main metamorphic minerals: biotite and muscovite) in the Taean Formation, with garnet being extremely rare, and aluminum-silicates absent, occurred below ca. $450^{\circ} \mathrm{C}$. These conditions were below the minimum required upper amphibolite facies metamorphism to form significant overgrowths around older zircon crystals (Williams, 2001; Parrish and Noble, 2003). Consequently, the ca. 280 Ma date from a zircon rim (Kee, 2011) probably reflects mixing with older material below the tiny outermost metamorphic rim. Recently de Jong et al. (2014) published the first highquality age estimates for timing of the metamorphism of the Taean Formation. Applying SHRIMP for U-Pb dating of titanite from a calc-silicate rock with a layerparallel main cleavage $S_{1}$, these authors obtained a well-defined regression line with a lower intercept age of $232.5 \pm 3.0 \mathrm{Ma}(\mathrm{MSWD}=1.2) .{ }^{40} \mathrm{Ar} /{ }^{39} \mathrm{Ar}$ laser probe dating of two non-deformed muscovite single grains in metapelites that cross-cut the main tectono-metamorphic fabric $\mathrm{S}_{1}$ or lie as non-deformed recrystallized grains within $\mathrm{S}_{2}$ yielded concordant pseudo-plateau ages $(1 \sigma)$ of $230.7 \pm 1.0$ and $228.8 \pm 1.0 \mathrm{Ma}$ (Fig. 9). One pronouncedly saddle-shaped age spectrum has identical ages of $237.5 \pm 0.4$ Ma and 237.1 \pm 0.4 Ma for the low and high temperature steps, respectively, which are much older than the pseudo-plateau age (Fig. 9). Some other complex muscovite 
${ }^{40} \mathrm{Ar} /{ }^{39} \mathrm{Ar}$ age spectra obtained from the Taean Formation also show clear evidence of older concordant low and high temperature steps of 241 and $243 \mathrm{Ma}$ for muscovite that was recrystallized around 228-231 Ma (saddle-minimum, or pseudo-plateau) (Han, 2014). These concordant low and high temperature steps, as well as the main peak around $231 \mathrm{Ma}$, are well expressed as (sub)peaks in a relative frequency plot of all age steps from these sample (Fig. 10). The 231 Ma mica recrystallization age is clearly concordant with the age of metamorphism shown by the ages of the titanite and the intrusion of the Mongsanpo syenite (Fig. 10). The complexities of these age spectra will be discussed in detail elsewhere in relation with electron probe micro analyses of these micas.

\subsubsection{Magmatic intrusions in the Taean Formation on Anmyeon Island}

The Taean Formation on Anmyeon Island is intruded by a swarm of NE to ENE striking about 0.5 to $7 \mathrm{~m}$ thick mafic dykes. Their texture varies from finegrained without visible plagioclase crystals to coarse-grained doleritic with randomly oriented plagioclase crystals (micro-gabbro-like), or occasionally with a flow banding parallel to the dyke margin. The dykes have neither vesicles nor chilled margins, suggesting relatively deep intrusion levels. These mafic dykes truncate the locally well-developed $S_{1}$ foliation in meta-pelites and some calc-silicate rocks, as well as $S_{2}$ and mesoscopic $\mathrm{F}_{2}$ folds to which this crenulation cleavage is axial planar (Fig. 8c).

The $10-15 \mathrm{~km}^{2}$ syenite body at Mongsanpo (Fig. 7) cuts the discordant intrusive contact between a 7-metres-thick mafic dyke and the moderately dipping layering in the Taean Formation, showing that the dyke intruded the meta-sediments before the syenite did. Zircon from the syenite gave a SHRIMP ${ }^{206} \mathrm{~Pb} /{ }^{238} \mathrm{U}$ age of 
$229.6 \pm 3.5 \mathrm{Ma}$ (Han, 2014), which is concordant to the ca. $229 \mathrm{Ma} \mathrm{U}-\mathrm{Pb}$ age obtained on zircon by D.L. Cho (2007). The course-grained syenite contains metrescale bodies of medium-grained mafic rocks. Contacts between both types of magmatic rocks are often sharp and straight, suggesting minimal chemical mixing between the two melts, but also gradational, rounded and undulating. A number of features in the Mongsanpo body (Fig. 11 a-c) can be attributed to mingling of mafic and felsic melts, showing that they coexisted intimately in (semi)liquid state, and did not mix due to the thermal, compositional and viscosity contrasts (Vernon, 1984; Barbarin, 2005; Sklyarov and Fedorovskii, 2006; Seo et al., 2010). Syenite melts are extensively injected into the mafic rocks in flame-like veins (Fig. 11a) or by netveining. Scattered mafic schlieren, as well as isolated, rounded and elongated decimeter-long pillow-like lobes of mafic enclaves define a preferred orientation in the syenite, and have darker and finer grained margins (Fig. 11b). These chilled margins and the much finer grain size of the mafic rocks point to relatively rapid crystallization (quenching) when they were injected into cooler, partially crystalline leucocratic rock. Upon cooling the partially crystallized mafic melt would be come more viscous and break-up into smaller scattered lobate-formed enclaves by flow of the syenite host. Such enclaves record magmatic strain of the host over a limited temperature-time range in its cooling history, their ellipticity depending mainly on viscosity contrast (Pesquera, 1994; Smith, 2000). At more elevated temperature the more mafic melt has a lower viscosity, but during progressively crystallisation becomes more viscous than the felsic melt (Smith, 2000). Interfaces between both magmatic rock types are deformed into small wavelength cuspate-lobate fold-like patterns, locally with a faint flow banding developed in the mafic rocks parallel to the contact (Fig. 11c). The angular cusps are an indication of the magnitude of the 
viscosity ratio (Smith, 2000), in Fig. 11c suggesting that the mafic rock is the more viscous in this case, reflecting advanced cooling. At the finer scale the interface between both rock types is also festoon-like almost dendritic, with feldspar crystals and aggregates pointing into the mafic rock also suggesting immiscibility (Fig. 11c, left and right side; Sklyarov and Fedorovskii, 2006).

Locally the syenite shows clear evidence of solid-state ductile tectonic deformation in centimeter to decimeter wide zones of lineated and very platy ultramylonite (Fig. 11d). The magmatic rocks also contain deformed and boudinaged quartz-tourmaline veins, the strongest deformed and thinnest parts contain a lineation of elongated quartz grains and oriented extended tourmaline crystals. These observations underscore that tectonism continued after the intrusion of these magmatic bodies. Asymmetric fabric elements like porphyroclast tails and SC-fabrics indicate top-to-the-West shear. A number of smaller bodies of granitic rocks in the Gonam Complex are variable ductilely deformed indicated by their strong quartzfeldspar tectonic fabric enhanced by stringers of extended NNW plunging tourmaline crystals (Fig. 11e). Such veins of tourmaline granite may form boudins, without a strong internal fabric, that cut through the axial plane of second-generation folds that already deform a shear fabric (Fig. 11f).

\section{4. ${ }^{40} \mathrm{Ar} /{ }^{39} \mathrm{Ar}$ geochronology}

\subsection{Analytical Procedure}


Following thorough ultrasonic rinsing in distilled water single muscovite grains, obtained by handpicking the $0.3-2.0 \mathrm{~mm}$ size fraction of crushed rock under a binocular zoom microscope, were wrapped in $\mathrm{Al}$ foil envelopes $(11 \mathrm{~mm} \times 11 \mathrm{~mm} \times$ $0.5 \mathrm{~mm}$ ), which were stacked in an irradiation can, with neutron flux monitors inserted after every 8 to 10 samples. Samples and standards (sanidine TCR-2; age: $28.608 \pm 0.033 \mathrm{Ma}$; Renne et al., 1998, 2010, 2011) were irradiated together at location $8 \mathrm{E}$ of the McMaster reactor (Hamilton, Canada) for 127 hours under $\mathrm{Cd}$ shielding with a J/h of $4.75 \times 10^{-5} \mathrm{~h}^{-1}$. The sample arrangement allowed monitoring of the neutron flux gradient with a precision of $\pm 0.2 \%$. Muscovite single grains were ${ }^{40} \mathrm{Ar} /{ }^{39} \mathrm{Ar}$ step-heated with a Synrad ${ }^{\circledR} \mathrm{CO}_{2}$ continuous laser at Geosciences Rennes, following the procedure outlined by Ruffet et al. (1991, 1995). Blanks were performed routinely at the start of an experiment and repeated typically after each third run, and subtracted from the subsequent sample gas fractions. Isotopic analyses were performed on a MAP $215^{\circledR}$ noble gas mass spectrometer. The five argon isotopes and the background baselines were measured in eleven cycles, in peak-jumping mode. All isotopic measurements are corrected for mass discrimination and atmospheric argon contamination, following Lee et al. (2006) and Mark et al. (2011), as well as K, $\mathrm{Ca}$ and $\mathrm{Cl}$ isotopic interferences. Decay constants used: Renne et al. (2011). Apparent age errors are plotted at the $1 \sigma$ level and do not include the errors on the ${ }^{40} \mathrm{Ar}^{*} /{ }^{39} \mathrm{Ar}_{\mathrm{K}}$ ratio and age of the monitor and decay constant. Plateau ages were calculated if $70 \%$ or more of the ${ }^{39} \mathrm{Ar}_{\mathrm{K}}$ was released in at least three or more contiguous steps, the apparent ages of which agreeing to within $1 \sigma$ of the integrated age of the plateau segment. The errors on the ${ }^{40} \mathrm{Ar}^{*}{ }^{39} \mathrm{Ar}_{\mathrm{K}}$ ratio and age of the monitor and decay constant are included in the final calculation of the error margins on the pseudo- 
plateau age or on apparent ages individually cited. The ${ }^{40} \mathrm{Ar} /{ }^{39} \mathrm{Ar}$ analytical data are listed in Table 1, and shown as age spectra in Fig. 12a-c.

\subsection{Results and interpretation}

${ }^{40} \mathrm{Ar} /{ }^{39} \mathrm{Ar}$ step-heating dating of originally metamorphic muscovite present as detrital grains in sandstones JK52, 53 and 56 of the Gimpo Group yielded two strikingly different types of age spectra that correspond to two different age groups (Fig. 12a-c; Table 1). In each of the samples JK52 and 53 we dated both a pure muscovite and a muscovite with some sizeable biotite inclusions. All four muscovite grains yielded well-defined, concordant plateau ages $(1 \sigma)$ of $231.4 \pm 0.8$ and $231.3 \pm 0.8 \mathrm{Ma}(\mathrm{JK} 52$; Fig. 12a) and $228.9 \pm 0.8$ and 230.6 $\pm 0.8 \mathrm{Ma}$ (JK53; Fig. 12b). Pure muscovite yielded better-defined age plateaux $\left(>95 \%{ }^{39}\right.$ Ar release) than the grains with some included biotite (85-92\% ${ }^{39} \mathrm{Ar}$ release). In contrast, muscovite grain JK56 has an irregular age spectrum with step ages between about 1600 and $1800 \mathrm{Ma}$ (Fig. 12c, Table 1).

Middle-Late Triassic and mid-Paleoproterozoic ages are also well represented in age frequency plots for detrital zircon from sandstones of the Daedong Supergroup (Jeon et al., 2007). The 1.6-1.8 Ga ${ }^{40} \mathrm{Ar} /{ }^{39} \mathrm{Ar}$ step ages are somewhat younger than the 1.8-1.9 Ga zircons, which might point to slow cooling of the Precambrian source rocks, or alternatively may have been derived from a source rock that differs from lithologies used for U-Pb dating of zircons. Our concordant ca. 231-229 Ma plateau ages of detrital muscovite are identical to ${ }^{40} \mathrm{Ar} /{ }^{39} \mathrm{Ar}$ ages of metamorphic mica and amphibole in the Weolhyeonri Complex, and muscovite from the Taean Formation, which are all between 231 and $228 \mathrm{Ma}$. These detrital ${ }^{40} \mathrm{Ar} /{ }^{39} \mathrm{Ar}$ muscovite ages 
compare well with 239-232 Ma and 252-213 Ma sub-peaks formed by magmatic zircons in relative frequency diagrams of zircon ages that Jeon et al. (2007) obtained for the Bansong and Nampo Groups, respectively. This shows that during deposition of the Gimpo Group in Early to Middle Jurassic boundary times, potential Late Triassic metamorphic and magmatic source rocks were probably widespread at the Earth surface. The observation that two muscovite grains with biotite inclusions have step ages that are only marginally different from those of the pure muscovite grain in each sample may suggest that cooling of these rocks in the Late Triassic was fast, as outlined below.

Usually, isotopic dates in metamorphic rocks are interpreted to record when the temperature in a geological system drops below a critical threshold, the closure temperature, permitting minerals to start accumulating isotopes formed by radioactive decay in their crystalline lattices. In addition to temperature, argon diffusion in minerals and isotopic closure depend on the mineral's chemistry (e.g., Fe/Mg ratio, halogen content), diffusion geometry, and grain size, as well as on the cooling rate, pressure and fluid-assisted recrystallization (e.g., Lister and Baldwin, 1996; Di Vincenzo and Palmeri, 2001; Harrison et al., 2009; Tartèse et al., 2011; Villa et al., 2014). Calculation of isotopic closure temperatures versus cooling rates using estimates of Arrhenius parameters - activation energy and diffusion coefficient - for biotite (Grove and Harrison, 1996) and muscovite (Harrison et al., 2009) reveals that the closure temperature for the former is between 125 and $175^{\circ} \mathrm{C}$ lower than the latter for diffusion dimensions between 0.1 and $1 \mathrm{~mm}$, and different cooling rates. Due to their difference in chemistry and crystal structure both mica types do not degas at the same energies during dating experiments in the laboratory. If the much smaller biotite inclusions and the host muscovite in samples JK52 and 53 would have had highly 
different ages, the dating would not have resulted in flat age spectra, but a complex ones with different step ages. This implies that both age components were not strongly different, which then suggests that cooling must have been relatively fast.

\section{Tectonic interpretation of isotopic ages}

\subsection{Tectonically-induced cooling}

Rates of post-metamorphic cooling are controlled primarily by exhumation mechanisms. Rapidly evolving terranes and tectonic systems often yield a small range of ages for mineral geochronometers that have very different closure temperatures, including polygenetic Th- and U-bearing accessory minerals formed at or close to peak metamorphic conditions (e.g., Dallmeyer et al., 1986; Dokka et al., 1986; Goodwin and Renne, 1991; Baldwin et al., 1993, 2004; Brown and Dallmeyer, 1996; Platt et al., 1998; Treloar et al., 2000; Di Vincenzo and Palmeri, 2001; Zeitler et al., 2001; de Jong 2003; Štípská et al., 2004; Çelik et al., 2006; Schulmann et al., 2008; Pitra et al., 2010; Wilke et al., 2010; Charles et al., 2012; Cubley et al., 2013a, b; Daoudene et al., 2013). Tectonically exhumed terranes generally experienced rapid cooling, whereas exhumation by erosion record slow cooling (e.g., Dallmeyer et al., 1986; Dokka et al., 1986; Baldwin et al., 1993, 2004; Brown and Dallmeyer, 1996; Platt et al., 1998; Charles et al., 2012; Cubley et al., 2013a, b; Daoudene et al., 2013; Scibiorski et al., 2015), unless erosion was forced by extreme exhumation and became the driving force, as exemplified by the eastern and western Himalayan syntaxes (e.g., Treloar et al., 2000; Zeitler et al., 2001). 
Many of the examples of very rapidly $\left(>100^{\circ} \mathrm{C} / \mathrm{Ma}\right)$ cooled high-grade metamorphic rocks are from metamorphic core complexes. Such crustal and lithospheric-scale features form by the extreme extension of not metamorphosed or low-grade metamorphic upper crustal rocks along low-angle normal faults (detachments), and exhume deeper crustal levels (e.g., Dallmeyer et al., 1986; Dokka et al., 1986; Vanderhaeghe et al., 2003; Rey et al., 2009; Le Pourhiet et al., 2012; Whitney et al., 2013). Footwall rocks of core complexes are thick ductilely deformed medium- to high-grade metamorphic rocks associated with partially molten middle to lower continental crust, very much like the Gyeonggi Massif. Removal of overburden due to extreme thinning of the hanging wall along such along a trans-crustal or translithospheric detachment faults leads to buoyant and viscous uplift of the footwall that is cooled during this process. Conversely, if the uplift exceeds $15 \mathrm{~km}$ hanging wall rocks can be metamorphosed up to amphibolite-facies grade and granitic wet-melt conditions if the strain rate is larger than the cooling rate (e.g. Dallmeyer et al. 1986). Syn-tectonic sediments in half-grabens can similarly be metamorphosed.

Metamorphic core complexes have been documented in areas marked by crustal extension interpreted as the result of gravitational collapse of a previously thickened crust (Buck, 1991; Brun, 1999; Corti et al., 2003; Jolivet et al., 2013). Their occurrence has been discussed for the North American Cordillera (e.g., Dallmeyer et al., 1986; Dokka et al., 1986; Norlander et al., 2002; Vanderhaeghe et al., 2003; Kruckenberg et al., 2008; Rey et al., 2009; Cubley et al., 2013a, b; Whitney et al., 2013), the eastern Mediterranean (Cyclades, western Turkey-Aegean) (Thomson et al., 2009; Dilek and Altunkaynak, 2009; Le Pourhiet et al., 2012; Jolivet et al., 2013), the Variscan Orogen of Europe (Brown and Dallmeyer, 1996; Ledru et al., 2001; Augier et al., 2015), and the central part of eastern Asia (Charles et al., 2012; 
Daoudene et al., 2013). Results of thermo-mechanical modelling of the evolution of many metamorphic core complexes show very rapid cooling after near-isothermal decompression under peak temperature conditions (e.g., Rey et al., 2009; Le Pourhiet et al., 2012).

\subsection{Fast cooling and exhumation: is the Gyeonggi Massif a core complex?}

If excess argon is not present, for a given sample or in area, hornblende generally has an older ${ }^{40} \mathrm{Ar} /{ }^{39} \mathrm{Ar}$ age than biotite as both minerals have different closure temperatures. The fact that de Jong and Ruffet (2014a) obtained concordant ${ }^{40} \mathrm{Ar} /{ }^{39} \mathrm{Ar}$ (pseudo)plateau ages for hornblende $(230.1 \pm 1.0$ and $229.8 \pm 1.0 \mathrm{Ma})$ and biotite $(228.1 \pm 1.0 \mathrm{Ma})($ Fig. 6$)$ thus shows that rocks in the Hongseong area have been cooled rapidly during the earliest Late Triassic. In rapidly cooled geological systems the closure temperatures for the K-Ar system are likely to be significantly higher than the values usually used in the literature, viz., $500 \pm 50^{\circ} \mathrm{C}$ for amphibole (Harrison, 1981; Baldwin et al., 1990) and 300-325 ${ }^{\circ} \mathrm{C}$ for biotite (e.g., Purdy and Jäger, 1976; Harrison et al., 1985) that are valid only for moderate cooling rates. In view of the age concordance for 0.5-1 mm diameter biotite and hornblende grains de Jong and Ruffet (2014a) used closure temperatures of $360^{\circ} \mathrm{C}$ and $650^{\circ} \mathrm{C}$, respectively. The latter temperature is in the upper part of the $550-650^{\circ} \mathrm{C}$ range for hornblende suggested by Villa (1998), which he had revised upward with respect to the closure temperature band width of 520-600 ${ }^{\circ} \mathrm{C}$ Dahl (1996) calculated for an effective diffusion radius of $80 \mu \mathrm{m}$ and a cooling rate of $\mathrm{ca} .200^{\circ} \mathrm{C} / \mathrm{Ma}$, using the ionic porosity model. Using these closure temperature estimates and the $\sim 2$ Ma difference between the average values of the hornblende and biotite single grain dates gives a cooling rate in the order 
of $150^{\circ} \mathrm{C} / \mathrm{Ma}$. Using the lowest estimate for hornblende closure in the K-Ar system $\left(500^{\circ} \mathrm{C}\right)$ would still imply a cooling rate of about $100^{\circ} \mathrm{C} / \mathrm{Ma}$.

The efficiency of cooling is also shown by the fact that these concordant 230$228 \mathrm{Ma}$ hornblende and biotite ${ }^{40} \mathrm{Ar} /{ }^{39} \mathrm{Ar}$ ages are almost identical within uncertainty with $\mathrm{U}-\mathrm{Pb}$ ages of metamorphic rims on zircons reported in the literature (e.g., Guo et al., 2005; S.W. Kim et al., 2006, 2008, 2011a, b; Kee, 2011). Rim ages are 234 to 236 Ma in adjacent Deokjeongri gneisses, 229 to 243 in the Weolhyeonri Complex (Fig. 4), averaging at Ma in various rocks in the Hongseong area, and between 235 and 237 Ma in the Gyeonggi Massif. We interpret these zircon rim ages in rocks of central Korea as dating their growth because the $\mathrm{U}-\mathrm{Th}-\mathrm{Pb}$ closure temperature of unaltered zircon is well over $900^{\circ} \mathrm{C}$ (Villa, 1998; Cherniak and Watson, 2001; Ireland and Williams, 2003; Reiners, 2009), much higher than the temperature during upper amphibolite facies experienced by these rocks. At least part of the multiple phases of partial melting experienced by the rocks of the Deokjeongri Gneiss Formation (Fig. 5a) must be related to this event, and thus of Late Triassic age. As suggested in section 3.1, the temperature during $\mathrm{M} 2$ was probably around $700-750^{\circ} \mathrm{C}$ in large parts of the Gyeonggi Massif, with moderate anatexis taking place, sufficient to form metamorphic rims around older zircon crystals. Taking an average age for M2 of 235 Ma and a temperature of $750^{\circ} \mathrm{C}$, cooling from the metamorphic conditions during this overprint to the ${ }^{40} \mathrm{Ar} /{ }^{39} \mathrm{Ar}$ closure temperature of $650^{\circ} \mathrm{C}$ for amphibole would, thus, have been completed in about $5 \mathrm{Ma}$. Oh et al. (2006a) inferred temperatures as high as $900-950^{\circ} \mathrm{C}$ for the formation of the Odesan spinel granulite, which they dated at 245 $\pm 10 \mathrm{Ma}$ using zircon. Using the ${ }^{40} \mathrm{Ar} /{ }^{39} \mathrm{Ar}$ hornblende age and these temperature-time estimates for M2, despite its large error, suggests that cooling took 15 Ma. Both approaches suggest cooling rates in the order of $20-60^{\circ} \mathrm{C} / \mathrm{Ma}$. The thermal history of 
the Deokjeongri gneisses, the Weolhyeonri Complex and the Gyeonggi Massif in the Late Triassic, with a period with a cooling rate of $20-60^{\circ} \mathrm{C} / \mathrm{Ma}$ followed by very fast cooling of $100-150^{\circ} \mathrm{C} / \mathrm{Ma}$ would fit into a particle part typical of a core complex characterized by early near isothermal decompression followed by fast cooling close to the low-angle detachment fault (Fig. 13). Magmatic rocks formed by decompressional melting cool during exhumation and can be ductilely deformed (Fig. $11 \mathrm{~d}-\mathrm{f}$ ) after passing the solidus in the upper crust close to the detachment (Fig. 13). Although the detailed structural geometry of the Korean Peninsula has been severely modified during the Jurassic Daebo tectonic phase, the overall architecture resembles that of a metamorphic core complex: the central part being occupied by the Gyeonggi Massif that experienced widespread Late Triassic low-pressure high-temperature metamorphism and partial melting due to extension and thinning, covered by much less metamorphic rocks of the Taean Formation and the Imjingang Belt, and possibly capped by Precambrian terranes of the Nangrim and Yeongnam Massifs (Fig. 13).

A series of very rare low-grade metamorphic sedimentary rocks on Deokjeok Island in the Yellow Sea, contain slightly metamorphosed conglomerate, which is cut by a $225 \pm 3$ Ma granitic dyke (Y. Kim et al., 2014). These rocks have been speculated to have been deposited as post-orogenic sediments deposited during the Triassic in an extensional basin. De Jong and Ruffet (2014a) explained the metamorphism of these coarse-grained immature sediments as due to their downfaulting into the rapidly exhuming still hot metamorphic rocks of the footwall (Fig. 13), as described for various core complexes. On the basis of a Rb-Sr syntectonic muscovite whole-rock isochron age of $226 \pm 1$ Ma Kim et al. (2000) argued in favour of ductile normal faulting on the Gyeonggi Shear Zone along the northern margin of the Gyeonggi Massif. It is possible that the ca. 220 Ma-old muscovite from mylonitic 
quartzite in the Juksung area is related to the same event, but its meaning is somewhat uncertain, as this age is only found in one sample.

\subsection{A ca. 230 Ma thermo-tectonic event in the Deokjeongri Complex and Taean}

\section{Formation}

Meta-sediments of the Taean Formation on Anmyeon Island yielded concordant $233 \pm 3 \mathrm{Ma}$ (titanite, U-Pb SHRIMP) and 230.7 and 228.8 Ma (muscovite, ${ }^{40} \mathrm{Ar} /{ }^{39} \mathrm{Ar}$, errors 1.0 Ma) dates (de Jong et al., 2014). Metamorphism probably occurred between 400 and $450^{\circ} \mathrm{C}$. This is well below the closure temperature of titanite $\left(660-700^{\circ} \mathrm{C}\right.$, Scott and St. Onge, 1995; Villa, 1998; Frost et al., 2000) and muscovite $\left(420-520^{\circ} \mathrm{C}\right.$, diffusion dimensions $0.5-1.0 \mathrm{~mm}$, cooling rates of 1$100^{\circ} \mathrm{C} / \mathrm{Ma}$, pressures of $0.5 \mathrm{GPa}$ : Harrison et al. (2009); $500-550^{\circ} \mathrm{C}$ : Villa et al. (2014) for muscovite that is not deformed). Thus, these 233-229 Ma mineral dates represent metamorphic recrystallization ages instead of cooling ages. Consequently, the Taean Formation has been metamorphosed in the Carnian with a timing that is strikingly similar to the period of fast cooling of the Hongseong area, about $50 \mathrm{~km}$ to the East (Fig. 1). The ca. 229.6 Ma syenitic magmatism at Mongsanpo (Fig. 7; Kee, 2011; Han, 2014), as well as the mafic magmatism on Anmyeon Island, occurring as enclaves in the syenite and as doleritic dykes, took place during this time span too. Consequently, metamorphism of the Taean Formation and syenitic magmatism in and around Anmyeon Island are coeval. Mica and titanite are from rocks located at 6.5 to $20 \mathrm{~km}$ from the dated syenite pluton (Fig. 7), which does not show contact metamorphism. The mineral ages are therefore probably not due to the heating by the relative small intrusion itself. Also pleading against a simple contact metamorphism 
interpretation is the fact that the much more voluminous and widespread Jurassic plutonism has not resulted in formation of similar-aged rims around zircon. The Haemi intrusion in the Hongseong area (Fig. 4) has the same age (230-234 Ma; Choi et al., 2009; Seo et al., 2010; Cheong et al., 2014), which is identical within uncertainty with the hornblende and biotite ${ }^{40} \mathrm{Ar} /{ }^{39} \mathrm{Ar}$ plateau ages in the Deokjeongri Complex, and the average rim age of zircons in this area. Therefore, the Late Triassic metamorphism and magmatism that strongly affected rocks at structurally different levels probably have a common tectonic cause. Furthermore, the present study reveals the presence of ca. 231-229-Ma-old detrital muscovite (section 4.2, Fig. 12a-c) in the Early-Middle Jurassic Gimpo Group sandstones, cropping out about $150 \mathrm{~km}$ to the Northeast, indicating the importance of this Late Triassic event. The syenitic magmatism and the intrusion of the doleritic dyke swarm on Anmyeon Island took place after the area was affected by two superimposed folding phases. However, a number of such Late Triassic intrusive rocks on Anmyeon Island, both in the Taean Formation and their probable substratum formed by Proterozoic gneiss of the Gonam Complex are affected by local, but intense mylonitization (Fig. 11d, e). This implies that ductile deformation continued after intrusion of these ca. 229.6 Ma-old rocks. The ca. 226 Ma age of the Gyeonggi Shear Zone would fit into this picture.

\subsection{A ca. 240 Ma event in the northern Gyeonggi Massif and Taean Formation}

Near concordant ca. 243 and $240 \mathrm{Ma}{ }^{40} \mathrm{Ar} /{ }^{39} \mathrm{Ar}$ (pseudo)plateau ages (Fig. 3a, b) are recorded by muscovite from the strongly retrogressed and ductilely deformed rocks in the top of the northern Gyeonggi Massif. Consequently, at least part of the main ductile deformation, retrogression and cooling of these rocks took place in the Middle 
Triassic. The saddle-shape of the ${ }^{40} \mathrm{Ar} /{ }^{39} \mathrm{Ar}$ age spectra (Fig. 9) of Paleozoic metapelites of the Taean Formation on Anmyeon Island (Fig. 7) implies that the partially recrystallized muscovite contains relics of an earlier isotopic system than the one indicated by the 229-231 Ma (pseudo)plateau ages of the younger saddle minimum in the intermediate temperature steps. The inherited, not completely recrystallized, domain would correspond to the concordant low and high temperature steps of 237.5 and 237.1 Ma, respectively (Fig. 9). Some other complex muscovite ${ }^{40} \mathrm{Ar} /{ }^{39} \mathrm{Ar}$ age spectra obtained from the Taean Formation on the island also show clear evidence of older concordant low and high temperature steps of 240 and $243 \mathrm{Ma}$ for muscovite that was recrystallized around $231 \mathrm{Ma}$ (Fig. 10). Similar age spectra for partially recrystallized muscovite from metamorphic and magmatic rocks have been interpreted similarly (e.g., Cheilletz et al., 1999; Alexandrov et al., 2002; Castonguay et al., 2007; de Jong et al., 2009; Tartèse et al., 2011).

The presence of an older isotope system in Taean muscovites that has not been completely overprinted by recrystallization around ca. 231-229 Ma agrees with geological observations. The dated muscovite single grains occur as non-deformed grains that cross-cut the main tectono-metamorphic fabric in greenschist facies metapelites, or are present as non-deformed grains in samples with a well-developed $\mathrm{S}_{2}$, which is truncated by non-deformed doleritic dykes (Fig. 8c). At Mongsanpo one of such dykes is cut by a 229.5 Ma-old syenite. This clearly shows that the two phases of ductile deformation that affected the Taean metasediments occurred during an earlier tectono-metamorphic phase that produced folds and cleavages around $240 \pm 3$ Ma (Fig. 10), likely during a collision event.

The finding of 243-237 $\mathrm{Ma}{ }^{40} \mathrm{Ar} /{ }^{39} \mathrm{Ar}$ muscovite ages and age components at widely separated locations shows that a Middle Triassic tectonic event that produced 
deformation structures must have been of regional extent. It also implies that the strong ca. 230-235 Ma-old metamorphic recrystallization did not affect all parts of the Gyeonggi Massif, or that the massif may contain important tectonic discontinuities. Isotopic ages of $\mathrm{U}$-bearing accessory minerals in the range of 240 to $260 \mathrm{Ma}$ are relatively common in Korean rocks (Gyeonggi Massif; Suzuki, 2009; Lee et al., 2014; Yengkhom et al., 2014; Imjingang Belt and correlatives; D.L. Cho et al., 1996, 2005; Kim et al., 2014), which are usually regarded as dating the collision (e.g., Ree et al., 1996; Kwon et al., 2009; Chough et al., 2013).

\section{Regional Tectonic meaning of isotopic ages}

In this section we look at the different aspects of the tectonic evolution of the Korean collision belt in the 228-235 Ma period characterized by a regional tectonically induced, magmatic and metamorphic pulse, which is probably related to the post or late collisional episode. The early Late Triassic regional metamorphism in Korea is too extensive to be only related to the magmatic intrusions, suggesting that the fundamental the thermal anomaly induced by mantle processes was ultimately responsible for both the metamorphism and magmatism.

\subsection{Late Triassic post-collisional magmatism and metamorphism}

Subsequent to crustal thickening, orogenic belts were usually affected by horizontal crustal extension, and late-tectonic or post-collisional magmatism that evolved during a short period i.e., a magmatic pulse. Extensional tectonic settings developed during continuing plate convergence show the development of shoshonitic 
rocks associated with low-, medium- and high-K calc-alkaline rocks that have their source in the mantle and typically evolve over a short time (Kay and Kay, 1993; Manley et al., 2000; Gill et al., 2004; Fowler et al., 2008; Kay and Coira, 2009). Such shoshonitic rocks, and associated granitoids, may form from potassic calc-alkaline magmas, which in turn were produced by partial melting of previously subductionmodified (metasomatized) sub-continental mantle lithosphere by mafic magmas and underplates created during adiabatic decompressional melting of upwelling hot asthenosphere (e.g., Davies and von Blanckenburg, 1995; Turner et al., 1996; Gill et al., 2004; Duggen et al., 2005; Dilek and Altunkaynak, 2009; von Raumer et al., 2014). This Mg-rich potassic magmatism has, consequently, been associated with thermal anomalies created in rifted areas in (continental) magmatic arcs, possibly by slab windows linked to subduction of aseismic and/or spreading ridges (Kay and Coira, 2009; Deng et al., 2011; von Raumer et al., 2014), or slab roll-back and steepening (Peccerillo, 2005; Dilek and Altunkaynak, 2009; Kay and Coira, 2009). In addition, such rocks characterize post-collisional settings where an elevated orogen may undergo gravity controlled extensional collapse and associated lithospheric thinning, related to Rayleigh-Taylor instability-related convective thinning (England and Houseman, 1989; Platt et al., 1998; Molnar and Stock, 2009), or thermomechanical removal of lower crust and uppermost mantle (delamination) (Turner et al., 1996, 1999; Gîrbacea and Frisch, 1998; Duggen et al., 2005), or break-off of the dense oceanic portion of the subducted slab and separation from the stuck buoyant continental portion (Liégeois and Black, 1987; Davies and von Blanckenburg, 1995 Brown and Dallmeyer, 1996; Ledru et al., 2001; Peccerillo, 2005; Schulmann et al., 2008; Dilek and Altunkaynak, 2009; von Raumer et al., 2014). The distinctive traceelement signature of the Late Triassic high-K calc-alkaline magmatic rocks in the 
central Gyeonggi Massif and rare plutons in the Ogcheon Belt and the Yeongnam Massif (Fig. 1; Williams et al., 2009; S.W. Kim 2011a), viz: (1) large-ion lithophile element enrichment ( $\mathrm{Rb}, \mathrm{Ba}, \mathrm{Sr}$, Th, K: 100-1000x with respect to the primitive mantle) and (2) variable depletion of high field strength elements ( $\mathrm{Nb}, \mathrm{Ta}, \mathrm{P}, \mathrm{Ti})$, agree with their formation by these processes.

Mg-rich potassic magmatism is thus due to tectonic replacement of cold lithosphere, for instance below an orogen, by hot asthenospheric mantle. The result is a massif increased heat flux into the crust both by conductive heat transport (hot asthenosphere) and by advective heat transport (magma) (Elliott et al., 1998; Thompson, 1999; Bodorkos et al., 2002). This steepens the lithosphere geotherm, leading to mid-crustal felsic and mafic plutonism. Numerical modelling by Thompson (1999) has shown that especially mafic intrusions, following asthenospheric upwelling and underplating of basaltic magma, are instrumental in raising the geotherm. The effect of such disturbed thermal regimes is significant heating of the lower crust and creation of a thermal anomaly that propagates upwards into the middle and upper crust (e.g., Bakker et al., 1989; Loosveld and Etheridge, 1990; van Wees et al., 1992; Bodorkos et al., 2002). Advection of voluminous magmas has the potential to raise temperatures in the middle crust very quickly (Loosveld and Etheridge, 1990; van Wees et al., 1992; Elliott et al., 1998; Bodorkos et al., 2002). Such mechanisms could thus create temperatures in the range of $700-900^{\circ} \mathrm{C}$ at depths of only 20-30 km, typical for high-temperature/low-medium-pressure metamorphism, and associated anatexis. Without additional heating from an advected basic heat source, generally underplated or interplated mafic to intermediate, mantle-derived magma, it is unlikely that the continental crust will ever acquire temperatures needed for fluid-absent melting, disregarding peraluminous leucogranites (Thompson, 1999). 
This corroborates the argument of Oh et al. (2006a) who underscored that the Late Triassic hypersthene-bearing monzonite intrusion in the eastern Gyeonggi Massif alone could not have been a sufficient heat source to produce the $>900^{\circ} \mathrm{C}$ temperature needed for the nearby granulite facies metamorphism, and that large mafic-ultramafic complexes at a deeper level were required. One of the ways to create ultrahigh temperature metamorphism producing granulites containing hercynitic low-Zn spinel and quartz is by advection of heat in the form of basaltic melts or diapiric emplacement of the asthenosphere (Brown, 2007; Harley, 2008; Kelsey, 2008).

The occurrence of mafic rocks mingled with the 229.6 Ma-old syenite and the dolerite dyke swarm on Anmyeon Island (section 3.3.3) clearly points to mafic underplating. Field relations on the island show that both magmatic bodies intruded the Taean Formation after the two main ductile deformation phases. This can also be inferred for the similar-aged (mostly 233-224 Ma) magmatic suite, including high-K calc-alkaline and shoshonitic series rocks, occurring throughout Korea, which shows the installation of an extensional tectonic regime in Late Triassic time after contraction-related structures were formed. Their $\mathrm{Nd}$ and $\mathrm{Sr}$ isotopic systematics suggest that the magmas from which most of these plutons formed were derived from mantle melts contaminated by middle to upper crustal materials (Williams et al., 2009; S.W. Kim et al., 2011a). This process probably has been the trigger for the observed regional Late Triassic metamorphism. This event affected the middle Paleozoic greenschist facies metamorphic Taean Formation $\left(\mathrm{T}<450^{\circ} \mathrm{C}\right.$; age: $233-229$ Ma), large parts of the Gyeonggi Massif (M2 event), the Deokjeongri gneisses and Weolhyeonri complex (upper amphibolite facies grade, accompanied by moderate but widespread anatexis; $\mathrm{P}=0.75 \mathrm{GPa}, \mathrm{T}=700-750^{\circ} \mathrm{C}$; age: $\sim 235-228 \mathrm{Ma}$ ), as well as the Odesan spinel granulites $\left(\mathrm{T}=900-950^{\circ} \mathrm{C}\right.$; probable age: $\left.245 \pm 10 \mathrm{Ma}\right)$. The 
regional thermal gradient in the Gyeonggi Massif indicated by the pressuretemperature conditions during this M2 event was probably somewhat lower than suggested by the granulites, but still in the order of $30-40^{\circ} \mathrm{C} / \mathrm{km}$. Such values correspond to thermal conditions found in many of the Cenozoic hyper-thermal basins present in the Alpine-Carpathian collision belt of Europe (Cermak, 1993), like e.g., the Alboran Basin, the Tyrrhenian Sea, western Turkey-Aegean and the Pannonian Basin. These extensional basins were formed in response to delamination, roll back and detachment of slabs (de Boorder et al., 1998; Wortel and Spakman, 2000; Duggen et al., 2005; Edwards and Grasemann, 2009; Jolivet et al., 2013). Much of the Neogene-Quaternary volcanism in the Mediterranean region is potassic and mantlederived (Gîrbacea and Frisch, 1998; Gill et al., 2004; Peccerillo, 2005; Duggen et al., 2005; Bianchini et al., 2008). Therefore, the Late Triassic magmatism and metamorphism in Korea probably reflect the rapid transfer of heat promoted by extension and magmatic underplating, raising the temperature of the cool lithosphere sufficiently to initiate lithospheric melting. This also implies that there is a distinct possibility that the $231 \pm 3 \mathrm{Ma}$ (Guo et al., 2005; Kim et al., 2006) constraint for the timing of the high-pressure, obtained by U-Pb SHRIMP dating of zircons in the pervasively retrogressed eclogite and garnet granulite in the Hongseong area also reflect the metamorphism related to the Late Triassic magmatic and thermal pulse, and has no bearing on the age of the high-pressure metamorphism in Korea. First of all, these ca. $231 \mathrm{Ma}$ ages are significantly younger than the most recently obtained age of $240 \pm 5 \mathrm{Ma}$ on the eclogite (Park et al., 2014b). Secondly, on the basis of rare earth element (REE) patterns indicative of eclogite facies metamorphism in ca. 231Ma-old rims of dated zircon grains, Kim et al. (2006) regarded this age as the timing of the high-pressure metamorphism. However, they also indicated that some 
recrystallized zircons have old cores with ca. 231 Ma ages but that retained premetamorphic magmatic zoning patterns and chemical composition. This disparity indicates that the observed approximately flat middle to heavy REE pattern and the absent negative Eu-anomaly in the zircon rims can no longer be taken as indicative for high-pressure metamorphism at around $231 \mathrm{Ma}$ : both data sets may no longer point to the same event. Li et al. (2008) and de Jong et al. (2009) discussed a comparable case of fluid-mediated resetting of zircon that recrystallized during the exhumation of high-pressure metamorphic rocks in the Tianshan (NW China), also in association with widespread post-collisional bi-modal magmatism.

\subsection{Slab detachment/delamination and possible consequences}

Numerical modelling (Gerya 2010; van Hunen and Allen, 2011, and references therein) showed that it can take over 5-30 million years between the establishment of the peak pressure conditions in a subducted crustal unit or continental collision belt and initiation of the process leading to slab break-off, resulting in asthenospheric upwelling. Slab break-off occurs in the part of the slab where tensile stresses are the largest, and in a collisional context, therefore, will typically occur at the oceanic side of the previous 'passive margin' (van Hunen and Allen, 2011; Duretz and Gerya, 2013). Therefore, plate strength is important for the time-lag between continental collision and slab break-off. This delay depends mostly on the strength, and thus age, of the previously subducted oceanic lithosphere, and ranges from 10 million years, for young, weak slabs, to 25 million years, for a 200Ma-old, strong slab (van Hunen and Allen, 2011). Lithospheric delamination, destabilization and convective removal of the dense lithospheric layer beneath rigid 
lithosphere occur on a similar timescale (e.g., England and Houseman, 1989; Arnold et al., 2001; Bodorkos et al., 2002). The latter authors underscored that the period over which crustal heating occurs may increase to 20-25 million years when the vertical distance between the middle crust where magmatism and metamorphism are manifest and the zone where the thermal anomaly is generated is in the order of 65 km. Data from Kim et al. (2011a) show that the Late Triassic high Ba-Sr magmatic suite in Korea has low HREE (Yb 0.6-2.2 ppm, av.1.2; Y = 6-28 ppm, av. 12.5) contents and show relatively steep HREE patterns (chondrite normalized $\mathrm{Gd} / \mathrm{Yb} \sim 2$ 5). Their data also show the almost exclusive lack of negative Eu anomalies. As Y and $\mathrm{Yb}$ fractionate in garnet and Eu in plagioclase this suggests that garnet was present as residual phase in the source of the magmas, but plagioclase was absent. Such a garnet-bearing, plagioclase-free source could be placed within a thickened lower crust and subducted slab or a mantle region. Using this reasoning Jiang et al. (2013) argued for a source region of high-K calc-alkaline granitoids in the western Kunlun orogeny below $\sim 50 \mathrm{~km}$. Duggen et al. (2005) established that partial melts in the garnet stability field generally have high $\mathrm{Dy} / \mathrm{Yb}$ ratios $(>2.5)$, whereas melting in the spinel stability field would produce melts with $\mathrm{Dy} / \mathrm{Yb}$ ratios below 1.5 . The data obtained by Kim et al. (2011a) show that the highest Dy/Yb ratios for Late Triassic intrusive rocks with $\mathrm{SiO}_{2}<55 \%$, and $\mathrm{MgO}>3.4 \%$, are: 2.7 and 3.4 (a mangerite and diorite in the Hongseong and Yangpyeong areas), and between 2.2 and 2.0 for the Macheon monzodiorites. This may suggest an origin within the garnet peridotite stability field at depths $\sim 70-80 \mathrm{~km}$ for the former and of $<60 \mathrm{~km}$ for the latter. The most mafic rocks in the Hongseong and Yangpyeong areas have very high $\mathrm{Cr}$ (500 ppm) and high Ni (> 100 ppm) contents. Such high values would point to a subduction-modified peridotite source (Jiang et al., 2010). 
For such a deep source of least $50 \mathrm{~km}$ or maybe as high deep as $75 \mathrm{~km}$ it may take 20-25 million years for crustal heating to occur. Modelling studies of slab breakoff point to time-lags in the order of 10-30 million years. Taking 230-235 Ma as age of the magmatic and metamorphism pulse related to the delamination or slab breakoff, the latter event and the climax of the original collision might have taken place 1030 million years earlier, that is during the $240-265$ Ma period. Recent ${ }^{40} \mathrm{Ar} /{ }^{39} \mathrm{Ar}$ dating of muscovite, biotite and hornblende single grains from different tectonic units in the Imjingang Belt yielded tightly clustered plateau ages of around $250 \mathrm{Ma}$ (de Jong and Ruffet, in prep.). These ages are within error of a concordant U-Pb SHRIMP age of $252.9 \pm 1.9 \mathrm{Ma}$ for a metamorphic overgrowth on detrital cores around zircons in a paragneiss in the Imjingang Belt, interpreted as dating the medium-pressure metamorphic peak (Cho et al., 2005). This would imply the collisional metamorphism and deformation, at least in the Imjingang belt, occurred around Permo-Triassic boundary times. Geochronology of many collision belts in the world has clearly documented that exhumation of (ultra)high-pressure metamorphic rocks is a fast process. Time-lags of 5-25 Ma between high-pressure conditions and emplacement at high crustal levels are commonly implied by the data (e.g., Treloar and Rex, 1990; Fossen and Dunlap, 1998; Milnes and Koyi, 2000; Treloar et al., 2003; de Jong 2003; Baldwin et al., 2004; Çelik et al., 2006; Schulmann et al., 2008; Qui et al., 2010; Wilke et al., 2010). Slab detachment may occur after $\sim 15$ millions years of continental subduction (van Hunen and Allen, 2011; Duretz and Gerya, 2013). This would imply that eclogite facies metamorphism and subduction in the Korean tectonic system might have occurred possibly 10 to 20 million years earlier than the $240-265$ Ma period, that is in the Late Permian. This then implies that the isotopic age estimate 
for the eclogite facies metamorphism of $240 \pm 5 \mathrm{Ma}$ (Park et al., 2014b) is probably too young.

The Gyeonggi Massif, which is strongly affected by metamorphism in the latest Permian to late Middle Triassic, is bordered by two Precambrian terrains, the Nangrim and Yeongnam massifs (Figs. 1 and 12), that are essentially not affected by this, and which have been correlated to the North China Craton (Chough et al., 2000; Kwon et al., 2009; Oh, 2012). Subduction of oceanic lithosphere below a continental crustal domain containing the Nangrim and Yongnam massifs seems the most straightforward way to account for the depths of $60-75 \mathrm{~km}$ indicated by the petrology of retrogressed high-pressure metamorphic rocks. Parts of the Gyeonggi Massif may also have been underthrust below this crustal domain. Such a configuration does not only explain the present-day configuration of the Precambrian terranes in Korea (Fig. 1), and the local high-pressure metamorphism, but also the important 235-228 Ma post-contractional metamorphism at lower crustal level, and the fast cooling that is linked to exhumation of the Gyeonggi Massif (Fig. 13). In response to such underthrusting of continental crust topography develops on the overriding plate (van Hunen and Allen, 2011; Duretz and Gerya, 2013). During slab detachment and delamination dense lithosphere is replaced by lower-density asthenosphere, which induces thermal uplift on the order of 100's of metres to several km (Arnold et al., 2001; Molnar and Stock, 2009; van Hunen and Allen, 2011; Duretz and Gerya, 2013). The Pyeongan Supergroup forms part of the youngest Paleozoic sedimentary cover series of Nangrim and Yongnam massifs. It comprises a thick Late Paleozoic clastic successions formed in shallow marine, deltaic, and fluvial environments (Chough et al., 2000). Deposition was terminated by thick non-marine sandstone-shale series probably in Late Permian time (Chang, 1997), in which feldspathic components are 
more abundant, implying a change in tectonic stability of the source area (Chough et al., 2000). This change in depositional environment in the overriding plate, and the absence of Late Permian (?) and Triassic sediments covering the Nangrim and Yongnam massifs may be related to topography generated by subduction initiation, underthrusting of crustal segments, and thermal uplift associated with slab break-off or delamination.

\section{Conclusions}

Our study has shown that:

1. The 235 to 229 Ma metamorphism must have been of regional extend, affecting both low to mid-crustal levels, producing amphibolite and granulite facies metamorphism and local anatexis (Gyeonggi Massif, Hongseong zone), and greenschist facies metamorphism at higher crustal levels (Taean Formation).

2. Cooling between 231 and $228 \mathrm{Ma}$ was fast at the end $\left(100-150^{\circ} \mathrm{C} / \mathrm{Ma}\right)$, whereas earlier cooling from peak temperature at 234-235 Ma conditions to hornblende closure was much less fast. Extension, heating and fast cooling were concentrated in the Gyeonggi Massif, suggesting that it formed a core complex in the Late Triassic.

3. The Late Triassic thermal pulse is nearly coeval with widespread postcollisional magmatism (237-226 Ma), suggesting the were linked. 
4. This Late Triassic magmatism manifested by mafic dykes and syenite plutons and granitoids is clearly developed after contractional structures, truncating several generations of folds and tectonic foliations.

5. The Late Triassic metamorphism and magmatism may reflect the rapid transfer of heat by combined advective and conductive asthenospheric heat transport promoted by extension and magmatic underplating. The heat supply was related to post or late collisional delamination of the lower crust and uppermost mantle, and/or oceanic slab break-off.

6. 237-243 Ma plateau ages (Gyeonggi Massif) and age components (Taean Formation) point to an older tectono-metamorphic event, which is partially to strongly overprinted. Deformation structures of rocks with these ages show that this late Middle Triassic event is likely to be related to collisional tectonism.

\section{Acknowledgements}

First and foremost the senior author would like to than Brian Windley to suggest the guest editors to extend an invitation to write a contribution to this special volume to honor his career. Before collaborating, the lead author first met Brian, like most geologist, via his stimulating book "The Evolving Continents" of which he bought the third edition in a bookshop downtown Leeds, and that reads like a novel on the tectonic evolution of the continental crust through time. The senior autho thanks Chang Whan Oh for discussion during a post-sampling excursion in the Hongseong area (Spring 2014), and other trips throughout Korea. Last, but most certainly not least, we thank Prof. Oh and an anonymous reviewer for their positive remarks and 
suggestions, which greatly helped clarify our thinking and stream-lining of the paper.

This research was supported by Basic Science Research Program through the National Research Foundation of Korea (NRF) funded by the Ministry of Education (NRF2011-0012900).

\section{References}

Alexandrov, P., Ruffet, G., Cheilletz, A., 2002. Muscovite recrystallization and saddle-shaped ${ }^{40} \mathrm{Ar} /{ }^{39} \mathrm{Ar}$ age spectra: example from the Blond granite (Massif Central, France). Geochim. Cosmochim. Acta 66, 1793-1807. http://dx.doi.org/10.1016/S0016-7037(01)00895-X

Arnold, J., Jacoby, W.R., Schmeling, H., Schott, B., 2001. Continental collision and the dynamic and thermal evolution of the Variscan orogenic crustal root - numerical models. Jou. Geodynam, 31, 273-291. http://dx.doi.org/10.1016/S0264-3707(00)00023-5

Augier, R., Choulet, F., Faure M., Turrillot, P., 2015. A turning-point in the evolution of the Variscan orogen: the ca. 325 Ma regional partial-melting event of the coastal South Armorican domain (South Brittany and Vendée, France). Bull. Soc. géol. France, 186, 63-91.

Bakker, H.E., de Jong, K., Helmers, H., Biermann, C., 1989. The geodynamic evolution of the Internal Zone of the Betic Cordilleras (SE Spain): a model based on structural analysis and geothermobarometry. J. metam. Geol., 7, 359-381. http://dx.doi.org/10.1111/j.15251314.1989.tb00603.x

Baldwin, S.L., Harrison, T.M., FitzGerald, J.D., 1990. Diffusion of ${ }^{40}$ Ar in metamorphic hornblende. Contrib. Mineral. Petrol., 105, 691-703. http://dx.doi.org/10.1007/BF00306534

Baldwin, S.L., Lister, G.S., Hill, E.J., Foster, D.A., McDougall, I., 1993. Thermochronologic constraints on the tectonic evolution of active metamorphic core complexes, D'Entrecasteaux Islands, Papua New Guinea. Tectonics 12, 611-628. http://dx.doi.org/10.1029/93TC00235

Baldwin, S.L., Monteleone, B.D., Webb, L.E., Fitzgerald, P.G., Grove, M., Hill, E.J., 2004. Pliocene eclogite exhumation at plate tectonic rates in eastern Papua New Guinea. Nature 431, 263-267. http://dx.doi.org/10.1038/nature 02846 
Barbarin, B., 2005. Mafic magmatic enclaves and mafic rocks associated with some granitoids of the central Sierra Nevada batholith, California: nature, origin, and relations with the hosts. Lithos, 80, 155-177. http://dx.doi.org/10.1016/j.lithos.2004.05.010

Bianchini, G., Beccaluva, L., Siena, F., 2008. Post-collisional and intraplate Cenozoic volcanism in the rifted Apennines/Adriatic domain. Lithos 101, 125-140. http://dx.doi.org/10.1016/j.lithos.2007.07.011

Bodorkos, S., Sandiford, M., Oliver, N.H.S., Cawood, P.A., 2002. High-T, low-P metamorphism in the Paleoproterozoic Halls Creek Orogen, northern Australia: the middle crustal response to a mantle-related transient thermal pulse. J. metam. Geol., 20, 217-237. http://dx.doi.org/10.1046/j.1525-1314.2002.00339.x

Brown, M., 2007. Metamorphic conditions in orogenic belts: a record of secular change. Int. Geol. Rev., 49, 193-234. http://dx.doi.org/10.2747/0020-6814.49.3.193

Brown, M., Dallmeyer, R.D., 1996. Rapid Variscan exhumation and role of magma in core complex formation: Southern Brittany metamorphic belt, France. J. metam. Geol., 14, 361-379. http://dx.doi.org/10.1111/j.1525-1314.1996.00361.x

Brun, J.-P. 1999. Narrow rifts versus wide rifts: inferences for the mechanics of rifting from laboratory experiments. Phil. Trans. Roy. Soc. London, A357, 695-712.

Buck, W.R. 1991. Modes of continental lithospheric extension. J. Geoph. Res., 96 (B12), 2016120178.

Castonguay, S., Ruffet, G., Tremblay, A., 2007. Dating polyphase deformation across low-grade metamorphic belts: An example based on ${ }^{40} \mathrm{Ar} /{ }^{39} \mathrm{Ar}$ muscovite age constraints from the southern Quebec Appalachians, Canada. Geol. Soc. Amer. Bull., 119, 978992http://dx.doi.org/10.1130/B26046.1

Çelik, Ö.F., Delaloye, M., Féraud, G., 2006. Precise ${ }^{40} \mathrm{Ar}-{ }^{39} \mathrm{Ar}$ ages from the metamorphic sole rocks of the Tauride Belt Ophiolites, southern Turkey: implications for the rapid cooling history. Geol. Mag., 143, 213-227. http://dx.doi.org/10.1017/S0016756805001524

Cermak, V., 1993. Lithospheric thermal regimes in Europe. Phys. Earth Planet. Int., 79, 179-193. http://dx.doi.org/10.1016/0031-9201(93)90147-2 
Chang, K.H., 1997. Korean peninsula. In: Moores, E.M., Fairbridge Rhodes, W. (Eds.), Encyclopedia of European and Asian Regional Geology, Encyclopedia of Earth Sciences Series, XXII, Springer Verlag, pp. 465-473.

Charles, N., Gumiaux, C., Augier, R., Chen, Y., Faure, M., Lin, W., Zhu, R., 2012. Metamorphic core complex dynamics and structural development: Field evidences from the Liaodong Peninsula (China, East Asia). Tectonophysics 560-561, 22-50. http://dx.doi.org/10.1016/j.tecto.2012.06.019

Cheilletz, A., Ruffet, G., Marignac, C., Kolli, O., Gasquet, D., Féraud, G., Bouillin, J.P., 1999.

${ }^{40} \mathrm{Ar} /{ }^{39} \mathrm{Ar}$ dating of shear zones in the Variscan basement of Greater Kabylia (Algeria). Evidence of an Eo-Alpine event at $128 \mathrm{Ma}$ (Hauterivian-Barremian boundary): geodynamic consequences. Tectonophysics 306, 97-116. http://dx.doi.org/10.1016/S0040-1951(99)00047-5

Cheong, C.-s., Cho, M., Choi, S.H., 2014. Lithospheric mantle signatures from zircon Hf isotopes of Late Triassic high-K plutons in the Gyeonggi Massif, and their tectonic implications. 2014 Fall Joint Ann. Conf. Geol. Soc. Korea. Jungsun (Korea), 29-31 October 2014. p. 164.

Cheong, C.-s., Jeong, G.Y., Kim, H., Choi, M.S., Lee, S.-H., Cho, M., 2003. Early Permian peak metamorphism recorded in $\mathrm{U}-\mathrm{Pb}$ system of black slates from the Ogcheon metamorphic belt, South Korea, and its tectonic implication. Chem. Geol., 193, 81-92.

http://dx.doi.org/10.1016/S0009-2541(02)00227-9

Cherniak, D.J., Watson, E.B., 2001. Pb diffusion in zircon. Chem. Geol., 172, 1999-2017. http://dx.doi.org/10.1016/j.chemgeo.2007.05.005

Cho, D.L., 2007. SHRIMP zircon dating of a low-grade meta-sandstone from the Taean Formation: Provenance and its tectonic implications. Korea Inst. Geosci. Miner. Resour. Bull., 11, 3-14. Cho, D.L., Kwon, S., Jeon, E.Y., Armstrong, R., 2005. SHRIMP U-Pb zircon ages of metamorphic rocks from the Samgot unit, Yeoncheon complex in the Imjingang belt, Korea: Implications for the Phanerozoic tectonics of East Asia. Geol. Soc. of Amer. Abstracts with Programs, 37, 388.

Cho, D.L., Lee, S.R., Armstrong, R., 2008. Termination of the Permo-Triassic Songrim (Indosinian) orogeny in the Ogcheon belt, South Korea: occurrence of ca. 220 Ma post-orogenic alkali granites and their tectonic implications. Lithos, 105, 191-200.

http://dx.doi.org/10.1016/j.lithos.2008.03.007 
Cho, D.L., Suzuki, K., Adachi, M., Chwae, U., 1996. A preliminary CHIME age determination of monazites from metamorphic and granitic rocks in the Gyeonggi Massif, Korea. J. Earth Planet. Sci. Nagoya Univ., 43, 49-65.

Cho, M., Cheong, W.-s., Ernst, W.G., Yi, K., Kim, J.-m., 2013a. SHRIMP U-Pb ages of detrital zircons in metasedimentary rocks of the central Ogcheon fold-thrust belt, Korea: Evidence for tectonic assembly of Paleozoic sedimentary protoliths. J. Asian Earth Sci., 63, 234-249. http://dx.doi.org/10.1016/j.jseaes.2012.08.020

Cho, M., Kim, Y., Ahn, J., 2007. Metamorphic evolution of the Imjingang Belt, Korea: Implications for Permo-Triassic collisional orogeny. Int. Geol. Rev., 49, 30-51. http://dx.doi.org/10.2747/0020-6814.49.1.30

Cho, M., Na, J., Yi, K., 2010. SHRIMP U-Pb ages of detrital zircons in metasandstones of the Taean Formation, Western Gyeonggi massif, Korea: Tectonic implications. Geosci. J., 14, 99-109. http://dx.doi.org/10.1007/s12303-010-0011-7

Cho, M., Yang, S.-y., Kim, T., Yi, K., 2013b. Dynamic recrystallization and metamorphic evolution of ca. 1.85 Ga quartzofeldspathic and cordierite-garnet gneisses, western Gyeonggi Massif, Korea. Geoph. Res. Abst., 15, EGU2013-6631.

Cho, Y., Cho, M., Lee, S.R., 1996. Granulite-facies metamorphism and P-T evolutionary path of cordierite gneiss in the Cheongpyeong-Yangpyeong area. J. Petrol. Soc. Korea 5, 52-65. (in Korean with English abstract)

Choi, D.K., Woo, J., Park, T.-Y., 2012. The Okcheon Supergroup in the Lake Chungju area, Korea: Neoproterozoic volcanic and glaciogenic sedimentary successions in a rift basin. Geosci. J., 16, 229-252. http://dx.doi.org/10.1007/s12303-012-0031-6

Choi, P.Y., Rhee, C.W., Lim, S.B., So, Y.S., 2008. Subdivision of the Upper Paleozoic Taean Formation in the Anmyeondo-Boryeong area, west Korea: a preliminary approach to the sedimentary organization and structural features. Geosci. J., 12, 373-384. http://dx.doi.org/10.1007/s12303-008-0037-2

Choi, S.G., Rajesh, V.J., Seo, J., Park, J.W., Oh, C.W., Park, S.J., Kim, S.W., 2009. Petrology, geochronology and tectonic implications of Mesozoic high $\mathrm{Ba}-\mathrm{Sr}$ granites in the Haemi area, Hongseong Belt, South Korea. Isl. Arc 18, 266-281. http://dx.doi.org/ 10.1111/j.14401738.2008.00622.x 
Chough, S.K., Kwon, S.-T., Ree, J.-H., Choi, D.K., 2000. Tectonic and sedimentary evolution of the Korean peninsula: a review and new view. Earth-Sci. Rev., 52, 175-225. http://dx.doi.org/10.1016/S0012-8252(00)00029-5

Chough, S.K., Lee, D.-J., Ree, J.-H., 2013. Whereabouts of the collision belt between the Sino-Korean and South China blocks in the northeast Asian margin. Geosci. J., 17, 397-401. http://dx.doi.org/10.1007/s12303-013-0057-4

Cluzel, D., Cadet, J., Lapierre, H., 1990. Early middle Paleozoic intraplate orogeny in the Ogcheon belt (South Korea): a new insight on the Paleozoic buildup of East Asia. Tectonics, 10, 1130-1151. http://dx.doi.org/10.1029/91TC00866

Cohen, K.M., Finney, S.C., Gibbard, P.L., Fan, J.-X., 2013; updated. The ICS International Chronostratigraphic Chart. Episodes 36, 199-204, http://www.stratigraphy.org/ICSchart/ChronostratChart2014-02.pdf

Corti, G., Bonini, M., Conticelli, S., Innocenti, F.. Manetti, P. Sokoutis, D. 2003. Analogue modelling of continental extension: a review focused on the relations between the patterns of deformation and the presence of magma. Earth-Sci. Rev., 63, 169-247. http://dx.doi.org/10.1016/S00128252(03)00035-7

Cubley, J.F., Pattison, D.R.M., Archibald, D.A., Jolivet, M., 2013a. Thermochronological constraints on the Eocene exhumation of the Grand Forks complex, British Columbia, based on ${ }^{40} \mathrm{Ar} /{ }^{39} \mathrm{Ar}$ and apatite fission track geochronology. Can. J. Earth Sci., 50, 576-598. http://dx.doi.org/10.1139/cjes-2012-0058

Cubley, J.F., Pattison, D.R.M., Tinkham, D.K., Fanning, C.M., 2013b. U-Pb geochronological constraints on the timing of episodic regional metamorphism and rapid high-T exhumation of the Grand Forks complex, British Columbia. Lithos, 156-159, 241-267. http://dx.doi.org/10.1016/j.lithos.2012.10.015

Dahl, P.S., 1996. The crystal-chemical basis for Ar retention in micas: inferences from interlayer partitioning and implications for geochronology. Contrib. Mineral. Petrol., 123, 22-39. http://dx.doi.org/10.1007/s004100050141

Dallmeyer, R.D., Snoke, A.W., McKee, E.H., 1986. The Mesozoic-Cenozoic tectonothermal evolution of the Ruby Mountains, East Humbolt Range, Nevada: A Cordilleran metamorphic core complex. Tectonics, 5, 931-954. http://dx.doi.org/10.1029/TC005i006p00931 
Davies, J.H., von Blanckenburg, F., 1995. Slab breakoff: a model of lithospheric detachment and its test in the magmatism and deformation of collisional orogens. Earth Planet. Sci. Lett., 129, 85102. http://dx.doi.org/10.1016/0012-821X(94)00237-S

de Boorder, H., Spakman, W., White, S.H., Wortel, M.J.R., 1998. Late Cenozoic mineralization, orogenic collapse and slab detachment in the European Alpine Belt. Earth Planet. Sci. Lett., 164, 569-575. http://dx.doi.org/10.1016/S0012-821X(98)00247-7

de Jong, K., 2003. Very fast exhumation of high-pressure metamorphic rocks with excess ${ }^{40} \mathrm{Ar}$ and inherited ${ }^{87} \mathrm{Sr}$, Betic Cordilleras, southern Spain. Lithos, 70, 91-110. http://dx.doi.org/10.1016/S0024-4937(03)00094-X

de Jong, K., Ruffet, G., 2014a. Tectonic implications of the very fast cooling shown by concordant 230-228 $\mathrm{Ma}{ }^{40} \mathrm{Ar} /{ }^{39} \mathrm{Ar}$ laser probe hornblende and biotite single grain ages in the Hongseong area. J. Geol. Soc. Korea. 50, 611-626. http://dx.doi.org/10.14770/jgsk.2014.50.5.611 (in Korean with English abstract). Original English typescript and data tables downloadable at <https://www.researchgate.net/profile/Koen_De_Jong/>

de Jong, K., Ruffet, G., 2014b. $243-220 \mathrm{Ma}{ }^{40} \mathrm{Ar} /{ }^{39} \mathrm{Ar}$ laser probe muscovite single grain ages in the northernmost Gyeonggi Massif (Juksung area) and their tectonic implications. J. Geol. Soc. Korea 50, 771-782. http://dx.doi.org/10.14770/jgsk.2014.50. 50.6.771 (in Korean with English abstract). Original English typescript and data tables downloadable at <https://www.researchgate.net/profile/Koen_De_Jong/>

de Jong, K., Han, S., Ruffet, G., Yi, K., 2014. First age constraints on the timing of metamorphism of the Taean Formation, Anmyeondo: concordant $233 \mathrm{Ma}$ U-Pb titanite and 231-229 $\mathrm{Ma}{ }^{40} \mathrm{Ar} /{ }^{39} \mathrm{Ar}$ muscovite ages. J. Geol. Soc. Korea 50, 593-609. http://dx.doi.org/10.14770/jgsk.2014.50.5.593 (in Korean with English abstract). Original English typescript and data tables downloadable at <https://www.researchgate.net/profile/Koen_De_Jong/>

de Jong, K, Wang, B., Faure, M., Shu, L.S., Cluzel, D., Charvet, J., Ruffet, G., and Chen, Y., 2009. New ${ }^{40} \mathrm{Ar} /{ }^{39} \mathrm{Ar}$ age constraints on the Late Palaeozoic tectonic evolution of the western Tianshan (Xinjiang, northwestern China), with emphasis on late Permian fluid ingress. Int. J. Earth Sci., 98, 1239-1258. http://dx.doi.org/10.1007/s00531-008-0338-8

Deng, J.H., Yang, X.Y., Sun, W.D., Huang, Y., Chi, Y.Y., Yu L.F., Zhang, Q.M., 2011. Petrology, geochemistry, and tectonic significance of Mesozoic shoshonitic volcanic rocks, Luzong 
volcanic basin, eastern China. Int. Geol. Rev., 54, 714-736.

http://dx.doi.org/10.1080/00206814.2011.580628

Dilek, Y., Altunkaynak, Ş., 2009, Geochemical and temporal evolution of Cenozoic magmatism in western Turkey: Mantle response to collision, slab breakoff, and lithospheric tearing in an orogenic belt. In: van Hinsbergen, D.J.J., Edwards, M.A., Govers, R. (Eds.), Collision and Collapse at the Africa-Arabia-Eurasia Subduction Zone. Geol. Soc., London, Spec. Publ., 311, pp. 213-233. http://dx.doi.org/10.1144/SP311.8

Di Vincenzo, G., Palmeri, R., 2001. An ${ }^{40} \mathrm{Ar}-{ }^{39} \mathrm{Ar}$ investigation of high-pressure metamorphism and the retrogressive history of mafic eclogites from the Lanterman Range (Antarctica): evidence against a simple temperature control on argon transport in amphibole. Contrib. Mineral. Petrol., 141, 15-35. http://dx.doi.org/10.1007/s004100000226

Dokka, R.K., Mahaffie, M.J., Snoke, A.W., 1986. Thermochronologic evidence of major tectonic denudation associated with detachment faulting, northern Ruby Mountains-east Humboldt range, Nevada. Tectonics 5, 995-1006. http://dx.doi.org/10.1029/TC005i007p00995

Duggen, S., Hoernle, K., van den Bogaard, P., Garbe-Schönberg, D., 2005. Post-collisional transition from subduction to intraplate-type magmatism in the westernmost Mediterranean: evidence for continental-edge delamination of subcontinental lithosphere. Jou. Petrol., 46, 1155-1201. http://dx.doi.org/10.1093/petrology/egi013

Duretz, T., Gerya, T.V., 2013. Slab detachment during continental collision: Influence of crustal rheology and interactions with lithospheric delamination. Tectonophysics, 602, 124-140. 10.1016/j.tecto.2012.12.024

Edwards, M.A., Grasemann, B., 2009. Mediterranean snapshots of accelerated slab retreat: subduction instability in stalled continental collision. In: van Hinsbergen, D.J.J., Edwards, M.A., Govers, R. (Eds.), Collision and Collapse at the Africa-Arabia-Eurasia Subduction Zone. Geol. Soc., London, Spec. Publ., 311, pp. 155-192. http://dx.doi.org/10.1144/SP311.6

Egawa, K., Lee, Y.L., 2008. Thermal maturity assessment of the Upper Triassic to Lower Jurassic Nampo Group, mid-west Korea: Reconstruction of thermal history. Isl. Arc 17, 109-128. http://dx.doi.org/10.1111/j.1440-1738.2007.00602.x 
Egawa, K., Lee, Y.L., 2009. Jurassic synorogenic basin filling in western Korea: sedimentary response to inception of the western Circum-Pacific orogeny. Basin Res., 21, 407-431. http://dx.doi.org/10.1111/j.1365-2117.2009.00408.x

Elliott, B.A., Rämö, O.T., Nironen, M., 1998. Mineral chemistry constraints on the evolution of the 1.88-1.87 Ga post-kinematic granite plutons in the Central Finland Granitoid Complex. Lithos 45, 109-129. http://dx.doi.org/10.1016/S0024-4937(98)00028-0

England, P.C., Houseman, G.A., 1989. Extension during continental convergence with application to the Tibetan Plateau. J. Geoph. Res., 94, 17561-17579. http://dx.doi.org/10.1029/JB094iB12p17561

Ernst, W.G., Cao, R., Jiang, J., 1988. Reconnaissance study of Precambrian metamorphic rocks, northeastern Sinokorean shield, People's Republic of China. Geol. Soc. Am. Bull., 100, 692701. http://dx.doi.org/10.1130/0016-7606(1988)100<0692:RSOPMR>2.3.CO;2

Fossen, H., Dunlap, W.J., 1998. Timing and kinematics of Caledonian thrusting and extensional collapse, southern Norway: Evidence from ${ }^{40} \mathrm{Ar} /{ }^{39} \mathrm{Ar}$ thermochronology. J. Struct. Geol., 20, 765-781. http://dx.doi.org/10.1016/S0191-8141(98)00007-8

Fowler, M.B., Kocks, H., Darbyshire, D.P.F., Greenwood, P.B., 2008. Petrogenesis of high Ba-Sr plutons from the Northern Highlands Terrane of the British Caledonian Province. Lithos, 105, 129-148. http://dx.doi.org/10.1016/j.lithos.2008.03.003

Frost, B.R., Chamberlain, K.R., Schumacher, J.C., 2000. Sphene (titanite): phase relations and role as a geochronometer. Chem. Geol., 172, 131-148. http://dx.doi.org/10.1016/S0009-2541(00)002400

Gerya, T.V., 2010. Introduction to numerical geodynamic modelling. Cambridge University Press, 345 pp.

Gill, R.C.O., Aparicio, A., El Azzouzi, M., Hernandez, J., Thirlwall, M.F., Bourgois, J., Marriner, G.F., 2004. Depleted arc volcanism in the Alboran Sea and shoshonitic volcanism in Morocco: geochemical and isotopic constraints on Neogene tectonic processes. Lithos, 78, 363-388. http://dx.doi.org/10.1016/j.lithos.2004.07.002

Gîrbacea, R., Frisch, W., 1998. Slab in the wrong place: Lower lithospheric mantle delamination in the last stage of the Eastern Carpathian subduction retreat. Geology, 26, 611-614. http://dx.doi.org/10.1130/0091-7613(1999)027<0665:SITWPL>2.3.CO;2 
Goodwin, L.B., Renne, P.R., 1991. Effects of progressive mylonitization on Ar retention in biotites from the Santa Rosa mylonite zone, California, and thermochronologic implications. Contrib. Mineral. Petrol., 108, 283-297.

Grove, M., Harrison, T.M., 1996. ${ }^{40}$ Ar* diffusion in Fe-rich biotite. Amer. Min., 81, 940-951.

Guo, J., Zhai, M.G., Oh, C.W., Kim, S.W., 2005. 230 Ma eclogite from Bibong, Hongseong area, Gyeonggi Massif, South Korea: HP metamorphism, zircon SHRIMP U-Pb ages and tectonic implication. Mitt. Öster. Mineral. Gesell., 150, 47.

Han, R., Ree, J.-H., Cho, D.-L., Kwon, S.-T., Armstrong, R., 2006. SHRIMP U-Pb zircon ages of pyroclastic rocks in the Bansong Group, Taebaeksan Basin, South Korea and their implication for the Mesozoic tectonics. Gondwana Res., 9, 106-117.

http://dx.doi.org/10.1016/j.gr.2005.06.006

Han, S.Y., 2014. Age constraints on the evolution of the Taean Formation obtained by SHRIMP U-Pb and ${ }^{40} \mathrm{Ar} /{ }^{39} \mathrm{Ar}$ laser probe geochronology. Unpubl. MSc. Thesis, Seoul National University, 75 pp.

Harley, S.L., 2008. Refining the P-T records of UHT crustal metamorphism. J. metam. Geol., 26, 125154. http://dx.doi.org/10.1111/j.1525-1314.2008.00765.x

Harrison, T.M., 1981. Diffusion of ${ }^{40} \mathrm{Ar}$ in hornblende. Contrib. Mineral. Petrol., 78, 324-331. http://dx.doi.org/10.1007/BF00398927

Harrison, T.M., Célérier, J., Aikman, A.B., Hermann, J., Heizler, M.T., 2009. Diffusion of ${ }^{40}$ Ar in muscovite. Geochim. Cosmochim. Acta 73, 1039-1051. http://dx.doi.org/10.1016/j.gca.2008.09.038

Harrison, T.M., Duncan, I., McDougall, I., 1985. Diffusion of ${ }^{40} \mathrm{Ar}$ in biotite: Temperature, pressure and compositional effects. Geochim. Cosmochim. Acta 49, 2461-2468.

Ireland, T.R., Williams, I.S., 2003. Considerations in zircon geochronology by SIMS. In: Hanchar, J.M., Hoskin, P.W.O. (eds.), Zircon: Reviews in Mineralogy and Geochemistry. Mineral. Soc. Amer., 53, 215-241. http://dx.doi.org/10.2113/0530215

Jeon, H., Cho, M., Kim, H., Horie, K., Hidaka, H., 2007. Early Archean to Middle Jurassic evolution of the Korean Peninsula and its correlation with Chinese cratons: SHRIMP U-Pb Zircon age constraints. J. Geol., 115, 525-539. http://dx.doi.org/10.1086/519776 
Jeong, Y.-J., Yi, K., Kamo, S.L., Cheong, C.-S., 2008. ID-TIMS single zircon age determination of mangerite in the eastern Gyeonggi massif, Korea. J. Geol. Soc., Korea 44, 425-433.

Jolivet, L., et al., 2013. Aegean tectonics: Strain localisation, slab tearing and trench retreat, Tectonophysics 597-598, 1-33. http://dx.doi.org/10.1016/j.tecto.2012.06.011

Jiang, Y.H., Jia, R.Y., Liu, Z., Liao, S.Y., Zhao, P., Zhou, Q., 2013. Origin of Middle Triassic high-K calc-alkaline granitoids and their potassic microgranular enclaves from the western Kunlun orogen, northwest China: A record of the closure of Paleo-Tethys. Lithos, 156-159, 13-30. http://dx.doi.org/10.1016/j.lithos.2012.10.004

Jiang, Y.H., Jin, G.D., Liao, S.Y., Zhou, Q., Zhao, P., 2010. Geochemical and Sr-Nd-Hf isotopic constraints on the origin of Late Triassic granitoids from the Qinling orogen, central China: Implications for a continental arc to continent-continent collision. Lithos, 117, 183-197. http://dx.doi.org/10.1016/j.lithos.2010.02.014

Kay, R.W., Kay, S.M., 1993. Delamination and delamination magmatism. Tectonophysics, 219, 177189.

Kay, S.M., Coira, B.L., 2009. Shallowing and steepening subduction zones, continental lithospheric loss, magmatism, and crustal flow under the Central Andean Altiplano-Puna Plateau. In: Kay, S.M., Ramos, V.A., Dickinson, W.R. (Eds.), Backbone of the Americas: Shallow Subduction, Plateau Uplift, and Ridge and Terrane Collision. Geol. Soc. Amer. Mem., 204, pp. 229-259. http://dx.doi.org/10.1130/2009.1204(11)

Kee, W.-S., (editor) 2008. Tectonic correlation of major crustal units and construction of geoscience system of Northeast Asia. Basic Res. Rep. Korea Inst. Geosci. Miner. Resour. Report GP2007004-03-02, 316p. (In Korean with English summary).

Kee, W.-S., (editor) 2011. Tectonic evolution of the upper crustal units in the mid-western part of the Korean peninsula. Basic Res. Rep. Korea Inst. Geosci. Miner. Resour. GP2009-012-01-2009(3), 254p. (In Korean with English summary).

Kelsey, D.E., 2008. On ultrahigh-temperature crustal metamorphism. Gondwana Res., 13, 1-29. http://dx.doi.org/10.1016/j.gr.2007.06.001

Kim, H., Cheong, C.-S., Cho, M., 2007. The effect of allanite inclusions on U-Pb step-leaching ages and Sm-Nd isotope systematics of garnet from the Ogcheon metamorphic belt, South Korea. Chem. Geol., 236, 27-41. http://dx.doi.org/10.1016/j.chemgeo.2006.08.014 
Kim, J.H., 1998. Tectonic framework of the Korean Peninsular. In: Koh, H.J., Lee, B.-J. (Eds.), Tectonic Evolution of East Asia. Proceedings of the first meeting of Japanese and Korean structure and tectonic research group. Korea Inst. Geol. Min. Mater., Seoul, pp. 3-17.

Kim, J.-M., Cheong, C.-S., Lee, S.-R., Cho, M., Yi, K., 2008. In-situ U-Pb titanite age of the Chuncheon amphibolite: Evidence for Triassic regional metamorphism in central Gyeonggi massif, South Korea, and its tectonic implication. Geosci. J., 12, 309-316.

Kim, J.-M., Yi, K., Jeong, Y.-J., Cheong, C.-S., 2011. Geochronological and geochemical constraints on the petrogenesis of Mesozoic high-K granitoids in the central Korean peninsula. Gondwana Research, 20, 608-620. http://dx.doi.org/10.1016/j.gr.2010.12.005

Kim, J.-N., Ree, J.-H., Kwon, S.-T., Park, Y., Choi, S.-J., Cheong, C.-S., 2000. The Kyonggi shear zone of the central Korean Peninsula: late orogenic inprint of the North and South China collision. J. Geol., 108, 469-478.

Kim, K.H., Suzuki, K., Lee, J.I., Jang, H.K., 2008. CHIME ages of monazites from metamorphic rocks from the Precambrian Gyeonggi Gneiss Complex in the Shiheung and Seosan Group of the Gyeonggi Massif, South Korea. Econ. Environ. Geol., 41, 173-181.

Kim, S.W., 2005. Amphibole ${ }^{40} \mathrm{Ar} /{ }^{39} \mathrm{Ar}$ Geochronology from the Okcheon Metamorphic Belt, South Korea and its Tectonic Implications. Gondwana Res., 8, 385-402. http://dx.doi.org/10.1016/S1342-937X(05)71142-4

Kim, S.W., Kee, W.S., 2010. Geochronology and geochemical characteristics of metavolcanics from Weolhyeonri tectonic complex in the Hongseong area, SW Gyeonggi Massif. J. Geol. Soc. Korea 46, 453-471. (in Korean with English abstract)

Kim, S.W., Kwon, S.-T., Koh, H.J., Yi, K., Jeong, Y., Santosh, M., 2011a. Geotectonic framework of Permo-Triassic magmatism within the Korean Peninsula. Gondwana Res., 20, 865-889. http://dx.doi.org/10.1016/j.gr.2011.05.005

Kim, S.W., Kwon, S., Santosh, M., Cho, D.L., Ryu, I.-C., 2014. Detrital zircon U-Pb geochronology and tectonic implications of the Paleozoic sequences in western South Korea. J. Asian Earth Sci. http://dx.doi.org/10.1016/j.jseaes.2014.05.022

Kim, S.W., Kwon, S., Santosh, M., Williams, I.S., Yi, K., 2011b. A Paleozoic subduction complex in Korea: SHRIMP zircon U-Pb ages and tectonic implications. Gondwana Res., 20, 890-903. http://dx.doi.org/10.1016/j.gr.2011.05.004 
Kim, S.W., Oh, C.W., Williams, I.S., Rubbato, D., Ryu, I.-C., Rajesh, V.J., Kim, C.-B., Guo, J., Zhai, M., 2006. Phanerozoic high-pressure eclogite and intermediate-pressure granulite facies metamorphism in the Gyeonggi Block, South Korea: implications for the eastward extension of the Dabie-Sulu continental collision zone. Lithos, 92, 357-377. http://dx.doi.org/10.1016/j.lithos.2006.03.050

Kim, S.W., Santosh, M., Park, N., Kwon, S., 2011c. Forearc serpentinite mélange from the Hongseong suture, South Korea. Gondwana Res., 20, 852-864. http://dx.doi.org/10.1016/j.gr.2011.01.012

Kim, S.W., Williams, I.S., Kwon, S., Oh, C.W., 2008. SHRIMP zircon geochronology and geochemical characteristics of metaplutonic rocks from the south-western Gyeonggi Block, Korea: implications for Paleoproterozoic to Mesozoic tectonic links between the Korean Peninsula and eastern China. Prec. Res., 162, 475-497. http://dx.doi.org/10.1016/j.precamres.2007.10.006

Kim, Y., Aum, H.W, Cheong, W., Kim, T., Yi, K., 2014. An occurrence of the post-orogenic Triassic strata on Deokjeok Island, western Gyeonggi massif, Korea. Geosci. J., 18, 137-147. http://dx.doi.org/10.1007/s12303-014-0027-5

Kim, Y., Cheong, C.-S., Lee, Y., Williams, I.S., 2009. SHRIMP allanite U-Th-Pb dating of bimodal Triassic metamorphism of Neoarchean tonalitic gneisses, Daeijak Island, central Korea. Geosci. J., 13, 305-315. http://dx.doi.org/10.1007/s12303-009-0029-x

Kruckenberg, S.C., Whitney, D.L., Teyssier, C., Fanning, C.M., Dunlap, W.J., 2008. Paleocene-Eocene migmatite crystallization, extension, and exhumation in the hinterland of the northern Cordillera: Okanogan dome, Washington USA. Geol. Soc. Amer. Bull., 120, 912-929. http://dx.doi.org/10.1130/B26153.1

Kwon, S., Kim, S.W., Santosh, M., 2013. Multiple generations of mafic-ultramafic rocks from the Hongseong suture zone, western South Korea: implications for the geodynamic evolution of NE Asia. Lithos, 160-161, 68-83. http://dx.doi.org/10.1016/j.lithos.2012.11.011

Kwon, S., Sajeev, K., Mitra, G., Park, Y., Kim, S.W., Ryu, I.-C., 2009. Evidence for Permo-Triassic collision in Far East Asia: The Korean collisional orogeny. Earth Planet. Sci. Lett., 279, 340349. http://dx.doi.org/10.1016/j.eps1.2009.01.016

Ledru, P., Courrioux, G., Dallain, C., Lardeaux, J.M., Montel, J.M., Vanderhaeghe, O., Vitel, G., 2001. The Velay dome (French Massif Central): melt generation and granite emplacement during 
orogenic evolution. Tectonophysics, 342, 207-237. http://dx.doi.org/10.1016/S00401951(01)00165-2

Lee, B.C., Oh C.W., Yengkhom, K.S., Yi, K., 2014. Paleoproterozoic magmatic and metamorphic events in the Hongcheon area, southern margin of the Northern Gyeonggi Massif in the Korean Peninsula, and their links to the Paleoproterozoic orogeny in the North China Craton. Prec. Res., 248, 17-38. http://dx.doi.org/10.1016/j.precamres.2014.04.003

Lee, J.Y., Marti, K., Severinghaus, J.P., Kawamura, K., Yoo, H.S., Lee, J.B., Kim, J.S., 2006. A redetermination of the isotopic abundances of atmospheric Ar. Geochim. Cosmochim. Acta 70, 4507-4512. http://dx.doi.org/ 10.1016/j.gca.2006.06.1563

Lee, S.R., Cho, K., 2012. Precambrian Crustal Evolution of the Korean Peninsula. J. Petrol. Soc. Korea 21, 89-112.

Lee, S.R., Cho, M., 2003. Metamorphic and tectonic evolution of the Hwacheon granulite complex, central Korea: composite P-T path resulting from two distinct crustal thickening events. J. Pet., $44,197-225$.

Lee, S.R., Cho, M., Cheong, C.-S., Kim, H., Wingate, M.T.D., 2003. Age, geochemistry, and tectonic significance of Neoproterozoic alkaline granitoids in the northwestern margin of the Gyeonggi massif, South Korea. Prec. Res., 122, 297-310. http://dx.doi.org/10.1016/S0301$9268(02) 00216-4$

Le Pourhiet, L., Huet, B., May, D.A., Labrousse, L., Jolivet, L., 2012. Kinematic interpretation of the 3D shapes of metamorphic core complexes, Geochem. Geophys. Geosyst., 13, Q09002. http://dx.doi.org/10.1029/2012GC004271.

Li, X.G., Liu, S.W., Wang, Z.Q., Han, B.F., Shu, G.M., Wang, T., 2008. Electron microprobe monazite geochronological constraints on the Late Palaeozoic tectonothermal evolution in the Chinese Tianshan, J. Geol. Soc., London, 165, 511-522. http://dx.doi.org/10.1144/ 0016-76492007-077

Liégeois, J.-P., Black, R., 1987. Alkaline magmatism subsequent to collision in the Pan-African belt of the Adrar des Iforas. In: Fitton, J.G., Upton, B.G.J. (Eds.), Alkaline Igneous Rocks. The Geological Society, Blackwell, Oxford, 30, pp. 381-401.

Lim, S.-B., Choi, H.I., Kim, B.C., Kim, J.C., 1999. Depositional systems of the sedimentary basin (I): Depositional systems and their evolution of the Proterozoic Paegryeong Group and Taean Formation. MOST/KIGAM, 116 pp. (in Korean with English abstract) 
Lim, S.-B., Chun, H.Y., Kim, Y.B., Kim, B.C., Cho, D.-L., 2005. Geologic ages, stratigraphy and geological structures of the metasedimentary strata in Bibong-Yeonmu area, NW Okcheon belt, Korea. J. Geol. Soc. Korea, 41, 335-368. (in Korean with English abstract)

Loosveld, R.J.H., Etheridge, M.A., 1990. A model for low pressure facies metamorphism during crustal thickening. J. metam. Geol., 8, 257-267. http://dx.doi.org/10.1111/j.15251314.1990.tb00472.x

Manley, C.R., Glazner, A.F., Farmer, G.L., 2000. Timing of volcanism in the Sierra Nevada of California: Evidence for Pliocene delamination of the batholithic root? Geology, 28, 811-814. http://dx.doi.org/10.1130/0091-7613(2000)028<0811:TOVITS>2.3.CO;2

Mark, D.F., Stuart, F.M., De Podesta, M., 2011. New high-precision measurements of the isotopic composition of atmospheric argon. Geochim. Cosmochim. Acta, 75, 7494-7501. http://dx.doi.org/ 10.1016/j.gca.2011.09.042

Maruyama, S., Isozaki, Y., Kimura, G., Terabayashi, M., 1997. Paleogeographic maps of the Japanese Islands: plate tectonic synthesis from 750 Ma to the present. Isl. Arc 6, 121-142. http://dx.doi.org/10.1111/j.1440-1738.1997.tb00043.x

Milnes, A.G., Koyi, H.A., 2000. Ductile rebound of an orogenic root: case study and numerical model of gravity tectonics in the Western Gneiss Complex, Caledonides, southern Norway. Terra Nova $12,1-7$.

Molnar, P., Stock, J.M., 2009. Slowing of Indian convergence with Asia since $20 \mathrm{Ma}$ and its implications for Tibetan mantle dynamics. Tectonics 28, TC 300 I. http://dx.doi.org/10.1029/ 2008 TC2271.

Na, J.-S., Kim, Y.-S., Cho, M., Yi, K., 2012. SHRIMP U-Pb ages of detrital zircons from metasedimentary rocks in the Yeongheung-Seonjae-Daebu Islands, Northwestern Gyeonggi Massif. J. Petrol. Soc. Korea 21, 31-45.

Norlander, B.H., Whitney, D.L., Teyssier, C., Vanderhaeghe, O., 2002. Partial melting and decompression of the Thor-Odin dome, Shuswap metamorphic core complex, Canadian Cordillera. Lithos, 61, 103-125. http://dx.doi.org/10.1016/S0024-4937(02)00075-0

Oh, C.W., 2012. The tectonic evolution of South Korea and Northeast Asia from Paleoproterozoic to Triassic. J. Petrol. Soc. Korea, 21, 59-87. 
Oh, C.W., Choi, S.-G., Seo, J., Rajesh, V.J., Lee, J.H., Zhai, M., Peng, P., 2009. Neoproterozoic tectonic evolution of the Hongseong area, southwestern Gyeonggi Massif, Korea; implication for the tectonic evolution of Northeast Asia. Gondwana Res., 16, 272-284. http://dx.doi.org/10.1016/j.gr.2009.04.001

Oh, C.W., Imayama, T., Yi, S.-B., Kim, T., Ryu, I.-C., Jeon, J., Yi, K., 2014. Middle Paleozoic metamorphism in the Hongseong area, South Korea, and tectonic significance for Paleozoic orogeny in northeast Asia. J. Asian Earth Sci., http://dx.doi.org/10.1016/j.jseaes.2014.08.011

Oh, C.W., Kim, S.W., Williams, I.S., 2006a. Spinel granulite in Odesan area, South Korea: Tectonic implications for the collision between the North and South China blocks. Lithos 92, 557-575. http://dx.doi.org/10.1016/j.lithos.2006.03.051

Oh, C.W., Kim, S.W., Choi, S.G., Zhai, M., Guo, J., Sajeev, K., 2005. First finding of eclogite facies metamorphic event in South Korea and its correlation with the Dabie-Sulu collision belt in China. J. Geol., 113, 226-232. http://dx.doi.org/10.1086/427671

Oh, C.W., Kim, S.W., Ryu, I.-C., Okada, T., Hyodo, H., Itaya, T., 2004. Tectono-metamorphic evolution of the Okcheon Metamorphic Belt, South Korea: Tectonic implications in East Asia. Isl. Arc 13, 387-402. http://dx.doi.org/10.1111/j.1440-1738.2004.00433.x

Oh, C.W., Sajeev, K., Kim, S.-W., Kwon, Y.W., 2006b. Mangerite magmatism associated with a probable Late-Permian to Triassic Hongseong-Odesan collision belt in South Korea. Gondwana Res., 9, 95-105. http://dx.doi.org/10.1016/j.gr.2005.06.005

Oh, C.W., Imayama, T., Lee, S.Y., Yi, S.-B., Yi, K., Lee, B.C., 2015. Permo-Triassic and Paleoproterozoic metamorphism related to continental collision in Yangpyeong, South Korea. Lithos, 216-217, 264-284. http://dx.doi.org/10.1016/j.lithos.2014.12.016

Park, K.-H., Kim, M.J., Yang, Y.S., Cho, K.O., 2010. Age distribution of the Jurassic Plutons in Korean Peninsula. J. Petrol. Soc. Korea 19, 269-281.

Park, S.-I., Kim, S.W., Kwon, S., Thanh, N.X., Yi, K., Santosh, M., 2014. Paleozoic tectonics of the southwestern Gyeonggi massif, South Korea: insight from geochemistry, chromian-spinel chemistry and SHRIMP U-Pb geochronology. Gondwana Res. http://dx.doi.org/10.1016/j.gr.2013.07.015. 
Park, S.-I., Kwon, S., Kim, S.W., Yi, K., Santosh, M., 2014. Continental origin of the Bibong eclogite, southwestern Gyeonggi massif, South Korea. J. Asian Earth Sci., http://dx.doi.org/10.1016/j.jseaes.2014.08.024

Parrish, R.R., Noble, S.R., 2003. Zircon U-Th-Pb Geochronology by Isotope Dilution - Thermal Ionization Mass Spectrometry (ID-TIMS). Rev. Mineral. Geochem., 53, 182-213. http://dx.doi.org/10.2113/0530183

Peccerillo, A., 2005. Plio-Quaternary volcanism in Italy - Petrology, Geochemistry, Geodynamics. Springer-Verlag, Berlin, Heidelberg. 365 pp.

Peng, P., Zhai, M., Guo, J., Zhang, H., Zhang, Y., 2008. Petrogenesis of Triassic post-collisional syenite plutons in the Sino-Korean craton: an example from North Korea. Geol. Mag., 145, 637-647. http://dx.doi.org/10.1017/S0016756808005037

Pesquera, A., 1994. Mafic enclaves in granitoid intrusions: a catastrophic model of rheological behaviour. Terra Nova, 6, 575-581.

Pitra, P., Ballèvre, M., Ruffet, G., 2010. Inverted metamorphic field gradient towards a Variscan suture zone (Champtoceaux Complex, Armorican Massif, France). J. metam. Geol., 28, 183-208. http://dx.doi.org/10.1111/j.1525-1314.2009.00862.x

Platt, J.P., Soto, J.-L., Whitehouse, M.J., Hurford, A.J, Kelley, S.P., 1998. Thermal evolution, rate of exhumation, and tectonic significance of metamorphic rocks from the floor of the Alboran extensional basin, western Mediterranean. Tectonics, 17, 671-689. http://dx.doi.org/10.1029/98TC02204

Purdy, J.W., Jäger, E., 1976. K-Ar ages on rock-forming minerals from the Central Alps. Mem. Ist. Geol. Mineral. Univ. Padova 30, 1-31.

Qiu, H.N., Wijbrans, J.R., Brouwer, F.M., Yun, J.B., Zhao, L.H., Xu, Y.G., 2010. Amphibolite facies retrograde metamorphism of the Zhujiachong eclogite, SE Dabieshan: ${ }^{40} \mathrm{Ar} /{ }^{39} \mathrm{Ar}$ age constraints from argon extraction using UV - laser microprobe, in vacuo crushing and stepwise heating. J. metam. Geol., 28, 477-487. http://dx.doi.org/10.1111/j.1525-1314.2010.00875.x

Ree, J.-H., Cho, M., Kwon, S.-T., Nakamura, E., 1996. Possible eastward extension of Chinese collision belt in South Korea: The Imjingang belt. Geology, 24, 1071-1074. http://dx.doi.org/10.1130/0091-7613(1996)024<1071:PEEOCC>2.3.CO;2 
Reiners, P.W., 2009. Nonmonotonic thermal histories and contrasting kinetics of multiple thermochronometers. Geochim. Cosmochim. Acta, 73, 3612-3629. http://dx.doi.org/10.1016/j.gca.2009.03.038

Renne, P.R., Balco, G., Ludwig, R.L., Mundil, R., Min, K., 2011. Response to the comment by W.H. Schwarz et al. on " Joint determination of ${ }^{40} \mathrm{~K}$ decay constants and ${ }^{40} \mathrm{Ar} * /{ }^{40} \mathrm{~K}$ for the Fish Canyon sanidine standard, and improved accuracy for ${ }^{40} \mathrm{Ar} /{ }^{39} \mathrm{Ar}$ geochronology" by P.R. Renne et al. (2010). Geochim. Cosmochim. Acta 75, 5097-5100. http://dx.doi.org/10.1016/j.gca.2011.06.021

Renne, P.R., Mundil, R., Balco, G., Min, K., Ludwig, R.L., 2010. Joint determination of ${ }^{40}$ K decay constants and ${ }^{40} \mathrm{Ar} * /{ }^{40} \mathrm{~K}$ for the Fish Canyon sanidine standard, and improved accuracy for ${ }^{40} \mathrm{Ar} /{ }^{39} \mathrm{Ar}$ geochronology. Geochim. Cosmochim. Acta 74, 5349-5367. http://dx.doi.org/10.1016/j.gca.2010.06.017

Renne, P.R., Swisher, C.C., Deino, A.L., Karner, D.B., Owens, T.L., DePaolo, D.J., 1998. Intercalibration of standards, absolute ages and uncertainties in ${ }^{40} \mathrm{Ar} /{ }^{39} \mathrm{Ar}$ dating. Chem. Geol., 145, 117-152. http://dx.doi.org/10

Rey, P.F., Teyssier, C., Whitney, D.L., 2009. Extension rates, crustal melting, and core complex dynamics. Geology, 37, 391-394. http://dx.doi.org/10.1130/G25460A.1

Ruffet, G., Féraud, G., Amouric M., 1991. Comparison of ${ }^{40} \mathrm{Ar}-{ }^{39} \mathrm{Ar}$ conventional and laser dating of biotites from the North Trégor Batholith. Geochim. Cosmochim. Acta 55, 1675-1688.

Ruffet, G., Féraud, G., Ballèvre, M., Kiénast, J.R., 1995. Plateau ages and excess argon in phengites: an ${ }^{40} \mathrm{Ar}-{ }^{39} \mathrm{Ar}$ conventional laser probe study of Alpine micas (Sesia zone, Western Alps, northern Italy). Chem. Geol., 121, 327-343.

Sagong, H., Kwon, S.-T., Ree, J.-H., 2005. Mesozoic episodic magmatism in South Korea and its tectonic implication. Tectonics 24. http://dx.doi.org/10.1029/2004TC001720

Schulmann, K., Lexa, O., Štípská, P., Racek, M., Tajčmanová, L., Konopásek, J., Edel, J.-B., Peschler, A., Lehmann, J., 2008. Vertical extrusion and horizontal channel flow of orogenic lower crust: key exhumation mechanisms in large hot orogens? J. metam. Geol., 26, 273-297. http://dx.doi.org/10.1111/j.1525-1314.2007.00755.x 
Scibiorski, E., Tohver, E., Jourdan, F., 2015. Rapid cooling and exhumation in the western part of the Mesoproterozoic Albany-Fraser Orogen, Western Australia. Prec. Res., http://dx.doi.org/10.1016/j.precamres.2015.02.005

Scott, D.G., St-Onge, M.R., 1995. Constraints on Pb closure temperature in titanite based on rocks from the Ungava orogen, Canada: implications for $\mathrm{U}-\mathrm{Pb}$ geochronology and $\mathrm{P}-\mathrm{T}-\mathrm{t}$ path determination. Geology 23, 1123-1126. http://dx.doi.org/10.1130/00917613(1995)023<1123:COPCTI>2.3.CO;2

Seo, J., Choi, S.-G., Oh, C.W., 2010. Petrology, geochemistry, and geochronology of the postcollisional Triassic mangerite and syenite in the Gwangcheon area, Hongseong Belt, South Korea. Gondwana Res., 18, 479-496. http://dx.doi.org/10.1016/j.gr.2009.12.009

Seo, J., Oh, C.W., Choi, S.G., Rajesh, V.J., 2013. Two ultramafic rock types in the Hongseong area, South Korea: tectonic significance for northeast Asia. Lithos 175-176, 30-39. http://dx.doi.org/10.1016/j.lithos.2013.04.014

Sklyarov, E.V., Fedorovskii, V.S., 2006. Magma mingling: Tectonic and geodynamic implications. Geotectonics 40, 120-134.

Smith, J.V., 2000. Structures on interfaces of mingled magmas, Stewart Island, New Zealand. Jou. Struct. Geol., 22, 123-133. http://dx.doi.org/10.1016/S0191-8141(99)00139-X

So, Y., Rhee, C.W., Choi, P.Y., Kee, W.S., Seo, J.Y., Lee, E.J., 2013. Distal turbidite fan/lobe succession of the Late Paleozoic Taean Formation, western Korea. Geosci. J., 17, 9-25. http://dx.doi.org/10.1007/s12303-013-0016-0

Štípská, P., Schulmann, K., Kröner, A., 2004. Vertical extrusion and middle crustal spreading of omphacite granulite: a model of syn-convergent exhumation (Bohemian Massif, Czech Republic). J. metam. Geol., 22, 179-198. http://dx.doi.org/10.1111/j.1525-1314.2004.00508.x

Suzuki, K., 2009. CHIME dating and age mapping of monazite in granulites and paragneisses from the Hwacheon area, Korea: implication to correlations to Chinese cratons. Geosci. J., 13, 275-292. http://dx.doi.org/10.1007/s12303-009-0027-z

Tartèse, R., Ruffet, G., Poujol, M., Boulvais, P., Ireland, T.R., 2011. Simultaneous resetting of the muscovite K-Ar and monazite U-Pb geochronometers: a story of fluids. Terra Nova, 23, 390398. http://dx.doi.org/10.1111/j.1365-3121.2011.01024.x 
Thompson, A.B., 1999. Some time-space relationships for crustal melting and granitic intrusion at various depths. In: Castro, A., Fernández, C., Vigneresse, J.-L. (Eds.), Understanding granites: integrating new and classical techniques. Geol. Soc., London, Spec. Publ., 168, 7-25. http://dx.doi.org/10.1144/GSL.SP.1999.168.01.02

Thomson, S.N., Ring, U., Brichau, S., Glodny, J., Will, T.M., 2009. Timing and nature of formation of the Ios metamorphic core complex, southern Cyclades, Greece. In: Ring U., Wernicke, B. (Eds.), Extending a Continent: Architecture, Rheology and Heat Budget. Geol. Soc., London, Spec, Publ,, 321, pp. 139-167. http://dx.doi.org/10.1144/SP321.7

Treloar, P.J., Rex, D.C., 1990. Post-metamorphic cooling history of the Indian plate crystalline stack, Pakistan Himalaya. J. Geol. Soc. London, 147, 735-738.

Treloar, P.J., O'Brien, P.J., Parrish, R.R., Khan, M.A., 2003. Exhumation of early Tertiary coesitebearing eclogite from Pakistan Himalaya. J. Geol. Soc. London, 160, 367-376. http://dx.doi.org/10.1144/0016-764902-075

Treloar, P.J., Rex, D.C., Guise, P.G., Wheeler, J., Hurford, A.J., Carter, A., 2000. Geochronological constraints on the evolution of the Nanga Parbat syntaxis, Pakistan Himalaya. In: Khan, M.A., Jan, M.Q., Treloar, P.J., Searle, M.P. (Eds.), Tectonics of Nanga Parbat and the Western Himalaya. Geol. Soc., London, Spec. Publ., 170, pp. 137-162. http://dx.doi.org/10.1144/GSL.SP.2000.170.01.01

Turner, S.P., Arnaud, N., Liu, J., Rogers, N., Hawkesworth, C., Harris, N., Kelley, S.P., van Calsteren, P., Deng, W., 1996. Post-collision, shoshonitic volcanism on the Tibetan Plateau: implications for convective thinning of the lithosphere and the source of ocean island basalts. J. Petrol. 37, $45-71$.

Turner, S.P., Platt, J.P., George, R.M.M., Kelley, S.P., Pearson, D.G., Nowell, G.M., 1999. Magmatism associated with orogenic collapse of the Betic-Alboran domain, SE Spain. J. Petrol., 40, 10111036.

Vanderhaeghe, O., Medvedev, S., Fullsack, P., Beaumont, C., Jamieson, R.A., 2003. Evolution of orogenic wedges and continental plateaux: insights from crustal thermalmechanical models overlying subducting mantle lithosphere. Geoph. J. Int., 153, 27-51. 
van Hunen, J., Allen, M.B., 2011. Continental collision and slab break-off: a comparison of 3-D numerical models with observations. Earth Planet. Sci. Lett., 302, 27-37. http://dx.doi.org/10.1016/j.eps1.2010.11.035

van Wees, J.D., de Jong, K., Cloetingh, S., 1992. Two dimensional P-T-t modelling and the dynamics of extension and inversion in the Betic Zone (SE Spain). Tectonophysics, 203, 305-324.

Vernon, R.H. 1984. Microgranitoid enclaves in granites globules of hybrid magma quenched in a plutonic environment. Nature, 309, 438-439.

Villa, I.M., 1998. Isotopic closure. Terra Nova 10, 42-47.

Villa, I.M., Bucher, S., Bousquet, R., Kleinhanns, I.C., Schmid, S.M., 2014. Dating polygenetic metamorphic assemblages along a transect across the Western Alps. J. Petrol, 55, 803-830. http://dx.doi.org/10.1093/petrology/egu007

von Blanckenburg, F., Davies, J.H., 1996. Feasibility of double slab breakoff (Cretaceous and Tertiary) during Alpine convergence. Eclogae Geol. Helv., 89, 111-127.

von Raumer, J.F., Finger, F., Veselá, P., Stampfli, G.M., 2014. Durbachites-Vaugnerites - a geodynamic marker in the central European Variscan orogen. Terra Nova 26, 85-95. http://dx.doi.org/10.1111/ter.12071

Whitney, D.L., Teyssier, C., Rey, P., Buck, W.R., 2013. Continental and oceanic core complexes. Geol. Soc. Amer. Bull., 125, 273-298. http://dx.doi.org/10.1130/B30754.1

Wilke, F.D.H., O’Brien, P.J., Gerdes, A., Timmerman, M.J., Sudo, M., Ahmed Khan, M., 2010. The multistage exhumation history of the Kaghan Valley UHP series, NW Himalaya, Pakistan from $\mathrm{U}-\mathrm{Pb}$ and ${ }^{40} \mathrm{Ar} /{ }^{39} \mathrm{Ar}$ ages. Eur. J. Mineral., 22, 703-719. http://dx.doi.org/10.1127/0935$1221 / 2010 / 0022-2051$

Williams, I.S., 2001. Response of detrital zircon and monazite, and their U-Pb isotopic systems, to regional metamorphism and host-rock partial melting, Cooma Complex, southeastern Australia. Austal. J. Earth Sci., 48, 557-580.

Williams, I.S., Cho, D.L., Kim, S.W., 2009. Geochronology, and geochemical and Nd-Sr isotopic characteristics of Triassic plutonic rocks in the Gyeonggi Massif, South Korea: Constraints on Triassic post-collisional magmatism. Lithos, 107, 239-256.

http://dx.doi.org/10.1016/j.lithos.2008.10.017 
Wortel, M.J.R., Spakman, W., 2000. Subduction and slab detachment in the Mediterranean-Carpathian region. Science, 290, 1910-1917.

Wu, F.-Y., Han, R.-H., Yang, J.-H., Wilde, S.A., Zhai, M.-G., Park, S.-C., 2007. Initial constraints on the timing of granitic magmatism in North Korea using $\mathrm{U}-\mathrm{Pb}$ zircon geochronology. Chem. Geol., 238 232-248. http://dx.doi.org/10.1016/j.chemgeo.2006.11.012

Yengkhom, K.S., Lee, B.C., Oh, C.W., Yi, K., Kang, J.H., 2014. Tectonic and deformation history of the Gyeonggi Massif in and around the Hongcheon area, and its implications in the tectonic evolution of the North China Craton. Prec. Res., 240, 37-59.

http://dx.doi.org/10.1016/j.precamres.2013.10.016

Yi, K., Cho, M., 2009. SHRIMP Geochronology and reaction texture of monazite from a retrogressive transitional layer, Hwacheon Granulite Complex, Korea. Geosci. J., 13, 293-304. http://dx.doi.org/10.1007/s12303-009-0028-y

Yin, A., Nie, S., 1993. An indentation model for the North and South China collision and the development of the Tan-Lu and Honam fault sysytem, eastern Asia. Tectonics, 12, 801-813. http://dx.doi.org/10.1029/93TC00313

Zeitler, P.K., Meltzer, A.S., Koons, P.O., Craw, D., Hallet, B., Chamberlain, C.P., Kidd, W.S.F., Park, S.K., Seeber, L., Bishop, M., Shroder, J., 2001. Erosion, Himalayan geodynamics, and the geomorphology of metamorphism. GSA Today, 11(1), 4-9.

Zhai, M., Guo, J., Li, Z., Chen, D., Peng, P., Li, T., Hou, Q., Fan, Q., 2007. Linking the Sulu UHP belt to the Korean Peninsula: Evidence from eclogite, Precambrian basement, and Paleozoic sedimentary basins. Gondwana Res., 12, 388-403. http://dx.doi.org/10.1016/j.gr.2007.02.003

\section{Figure Captions}

\section{Figure 1.}

Tectonic sketch map of the southern part of the Korean Peninsula. Maps of key areas discussed are outline; locations referred to in the text are marked; $\mathrm{H}$, Hongseong; $\mathrm{O}$, Odesan. 


\section{Figure 2.}

Geological sketch map of Juksung area based on Kee (2011) with sample locations; ${ }^{40} \mathrm{Ar} /{ }^{39} \mathrm{Ar}$ ages indicated from de Jong and Ruffet (2014b). DMZ, Demilitarized Zone; GSZ, Gyeonggi Shear Zone.

\section{Figure 3 a, b.}

Step-heating age spectra of muscovite single grains from quartzitic chlorite-mica schists in Juksung area (Fig. 2). Apparent age errors are plotted at the $1 \sigma$ level and do not include the errors on the ${ }^{40} \mathrm{Ar}^{*} /{ }^{39} \mathrm{Ar}_{\mathrm{K}}$ ratio and age of the monitor and decay constant.

\section{Figure 4 .}

Geological sketch map of the Hongseong area modified after Kee (2011), Kim et al. (2011b), de Jong and Ruffet (2014a); mafic and ultra mafic rocks after Oh et al. (2014). Isotopic ages from Kee (2011) (U-Pb, zircon) and de Jong and Ruffet (2014a) $\left({ }^{40} \mathrm{Ar} /{ }^{39} \mathrm{Ar}\right) . \mathrm{BB}$, Bibong.

\section{Figure 5 a-c.}

Field photographs (a) Anatexis shown by irregular veins and patches along the main foliation and shear zones cut by irregular veins of fine-grained non-deformed granitic rocks, Hongseong area, (b) folded marble with mafic-ultramafic lenses that occur jointly with (c) fine-grained brick red siliceous layers/fine quartzites, Gonam Complex, Anmyeon Island. 


\section{Figure 6}

Step-heating age spectra of hornblende and biotite single grains from amphibolites in the Hongseong area, locations, see Fig. 4, and a corresponding relative frequency plot of all step ages, based on data from de Jong et al. (2014). Apparent age errors are plotted at the $1 \sigma$ level and do not include the errors on the ${ }^{40} \operatorname{Ar}^{*} /{ }^{39} \operatorname{Ar}_{\mathrm{K}}$ ratio and age of the monitor and decay constant.

\section{Figure 7.}

Geological sketch map of Anmyeon Island based on Kee (2011), modified after de Jong et al. (2014). Isotopic ages from Kee (2011) (U-Pb, zircon) and de Jong et al. (2014) $\left({ }^{40} \mathrm{Ar} /{ }^{39} \mathrm{Ar}\right.$, mica; U-Pb, titanite). Age Mongsanpo syenite (SHRIMP U-Pb, zircon), after Han (2014); age intusive body in Gonam Complex from Kee (2011).

\section{Figure 8 a-c.}

Field photographs Anmyeon Island (a) The earliest cleavage $S_{1}$ is only locally developed in meta-pelites as the axial plane cleavage of rare recumbent tight to isoclinal folds; note the cross-cutting $\mathrm{S}_{2}$, which also refracts on sandstone layers. (b) Megascopic open to tight disharmonic flexural slip $\mathrm{F}_{2}$ folds. (c) Curved but not folded mafic dyke truncates small-scale $F_{2}$ folds and axial cleavage $S_{2}$ (parallel to the hammer handle).

\section{Figure 9.}

Step-heating age spectra of muscovite single grains from low-grade metapelites of the Taean Formation, Anmyeon Island (locations, Fig. 7), modified after de Jong et al. 
(2014). Apparent age errors are plotted at the $1 \sigma$ level and do not include the errors on the ${ }^{40} \mathrm{Ar}^{*} /{ }^{39} \mathrm{Ar}_{\mathrm{K}}$ ratio and age of the monitor and decay constant.

\section{Figure 10.}

Relatively frequency plot of all age steps of muscovite samples $(\mathrm{N}=6)$, based on data from Han (2014). The ca. 237 Ma peak corresponds to the concordant low- and hightemperature steps in sample JK20 (Fig. 9). Titanite U-Pb age (232.5 $\pm 3.0 \mathrm{Ma}$ ) from de Jong et al. (2014); Mongsanpo syenite (229.6 + 3.5 Ma, SHRIMP U-Pb, zircon) from Han (2014).

\section{Figure 11 a-f.}

a-c) Features attributable to mingling of syenite and mafic melts in the intrusive body at Mongsanpo. a) Flames of syenite invading mafic rocks. (b) Isolated pillow-like lobes of mafic enclaves define a preferred orientation in the syenite, note their darker and finer grained chilled margins. (c) Cuspate-concave contacts between syenite and mafic rock, suggesting magma mingling, note the faint flow banding in the mafic rock parallel to the contact. (d) Moderately eastward dipping ultra-mylonites developed in the syenite body (looking north). (e) NNW-plunging stringers of extended tourmaline crystals in a ductilely deformed granitic rock with a mylonitic quartz-feldspar fabric, Gonam Complex, Anmyeon Island. (f) Boudin of tourmaline granite truncates the axial plane foliation of an $\mathrm{F}_{2}$ fold, looking Northward down-plunge and parallel to the earlier stretching lineation. Note the crenulation of the earlier $S_{1}$ shear fabric in the $F_{2}$ hinge zone, Gonam Complex, Anmyeon Island.

\section{Figure 12 a-c.}


Step-heating age spectra of detrital muscovites from sandstones of the Gimpo Group in the Juksung area (Fig. 2) (a) JK52, (b) JK53, (c) JK56. Apparent age errors are plotted at the $1 \sigma$ level and do not include the errors on the ${ }^{40} \mathrm{Ar}^{*} /{ }^{39} \mathrm{Ar}_{\mathrm{K}}$ ratio and age of the monitor and decay constant.

\section{Figure 13.}

Cartoon section of a possible post-collisional configuration in the Korean tectonic system in the Late Triassic, showing a mantle upwarping, and resulting collapse of the isotherms over the extended and thinned region that coincides with the Gyeonggi Massif. Pre-stretching thickness of the brittle upper crust is about $18 \mathrm{~km}$. Isothermal surfaces in ${ }^{\circ} \mathrm{C}$. The particle path (double line) shows early near-isothermal decompression followed by fast cooling that takes over the thermal regime close to the detachment fault; polygon and square: approximate positions of biotite and hornblende closure, respectively. The dotted line represents the solidus, implying that magmatic rocks may be ductilely deformed during advanced exhumation and thinning, as is demonstrated by a number of Late Triassic intrusions in Anmyeon Island (Fig. 11 d-f). Modified after Rey et al. (2009) and Whitney et al. (2013).

\section{Table 1.}

${ }^{40} \mathrm{Ar} /{ }^{39} \mathrm{Ar}$ analytical data of laser step-heating of detrital muscovite single grains Gimpo Formation in the Juksung area (Fig. 2). 


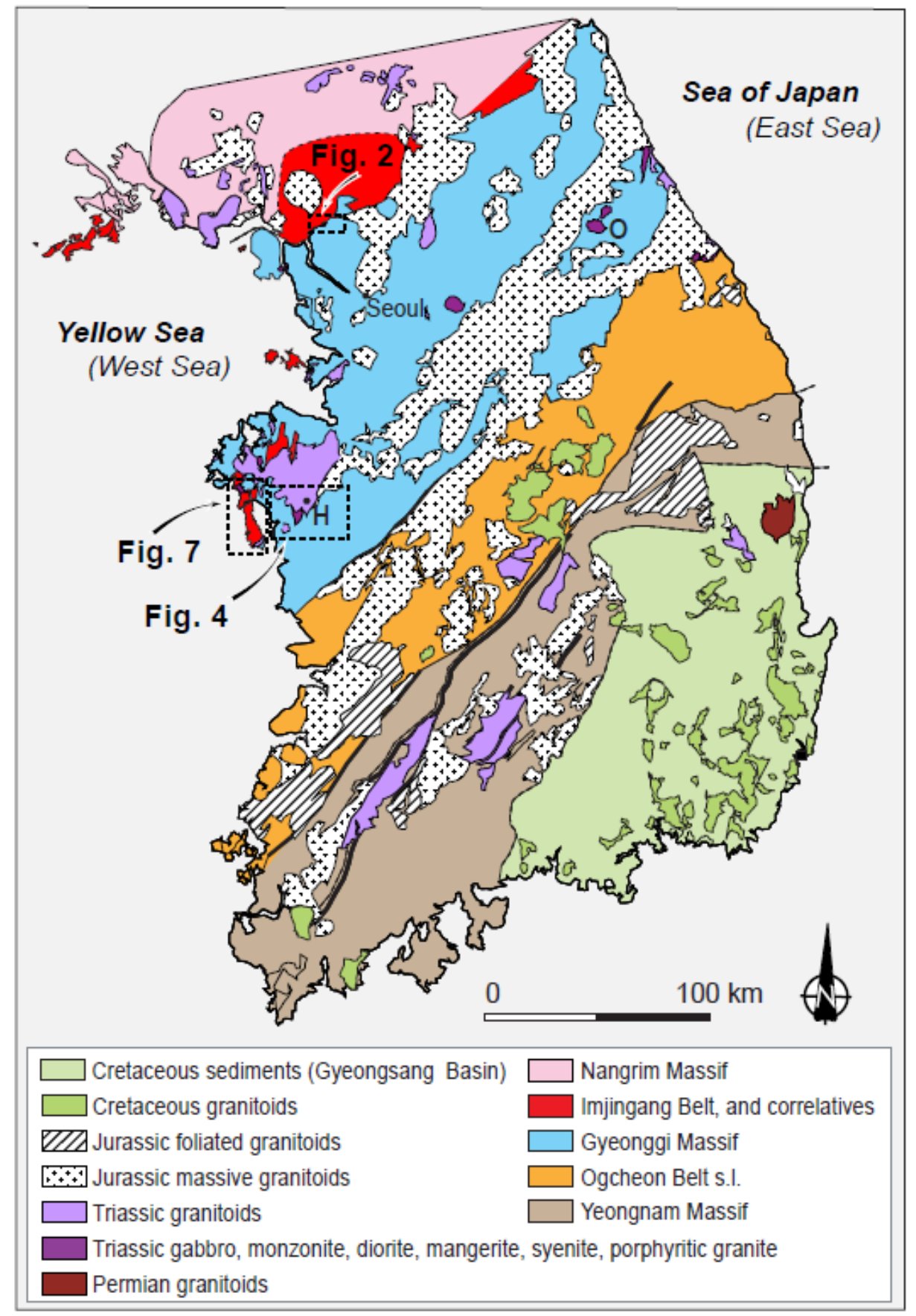

Figure 1.

Tectonic sketch map of the southern part of the Korean Peninsula.

Maps of key areas discussed are outline; locations referred to in the text are marked;

$\mathrm{H}$, Hongseong; $\mathrm{O}$, Odesan. 


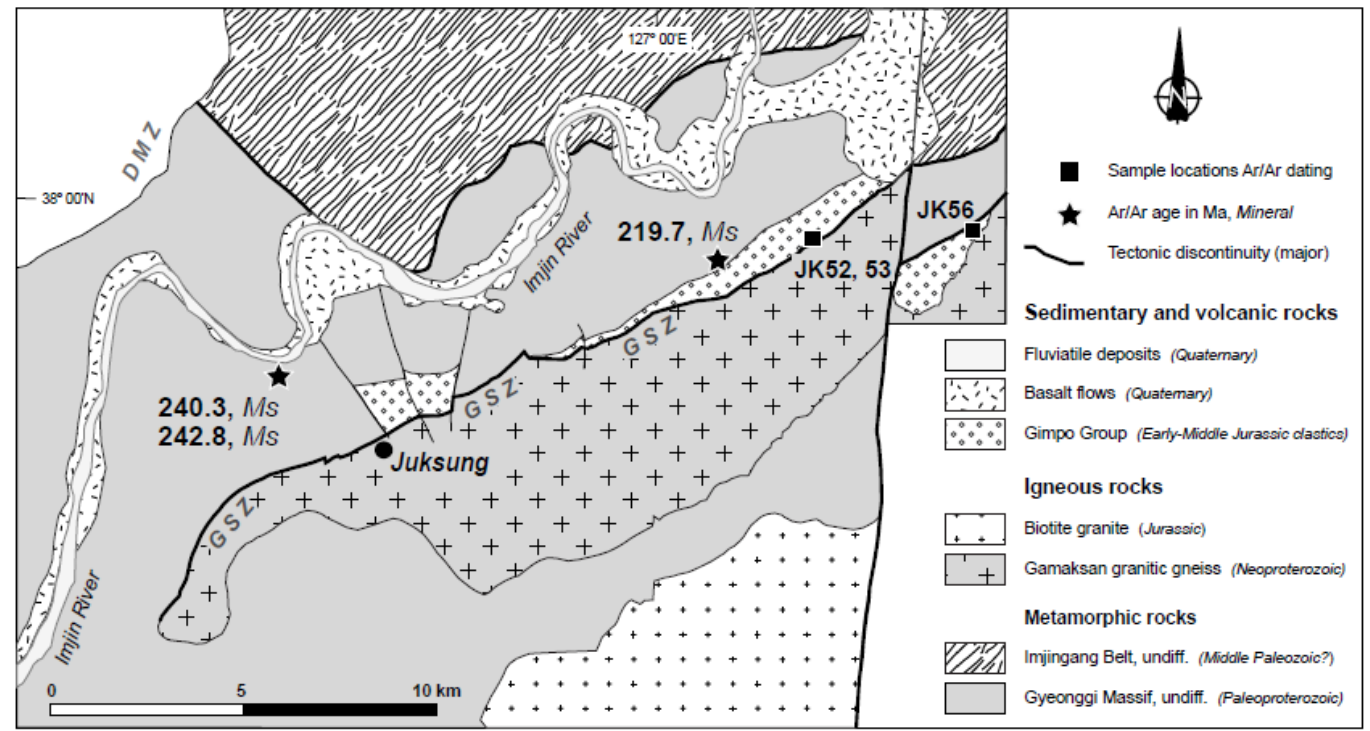

Figure 2.

Geological sketch map of Juksung area based on Kee (2011) with sample locations; 40Ar/39Ar ages indicated from de Jong and Ruffet (2014b) DMZ, Demilitarized Zone; GSZ, Gyeonggi Shear Zone. 


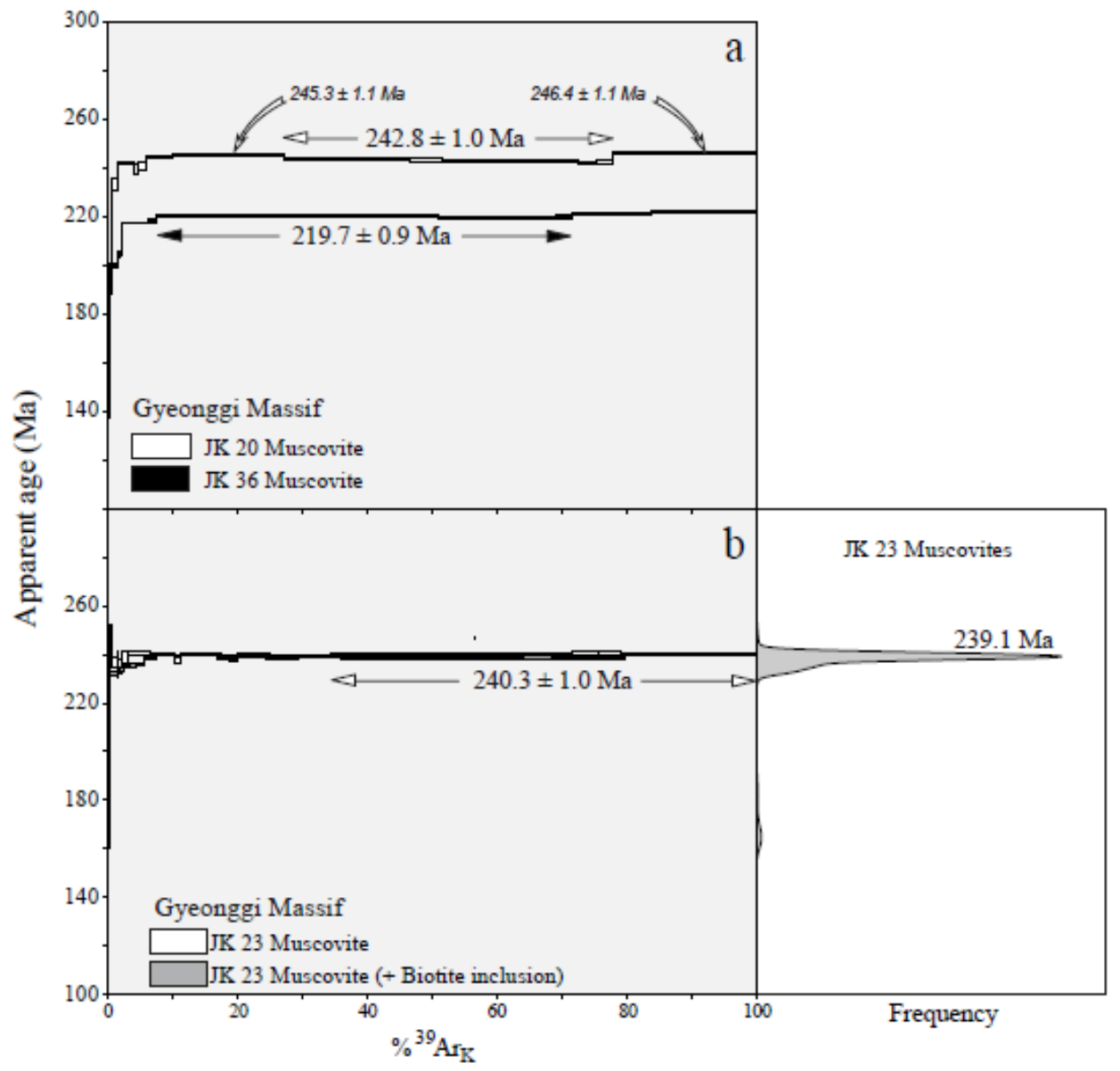

Figure $3 \mathrm{a}, \mathrm{b}$.

Step-heating age spectra of muscovite single grains from quartzitic chlorite-mica schists in Juksung area (Fig. 2). Apparent age errors are plotted at the $1 \sigma$ level and do not include the errors on the 40Ar ${ }^{\star} / 39 \mathrm{ArK}$ ratio and age of the monitor and decay constant. 


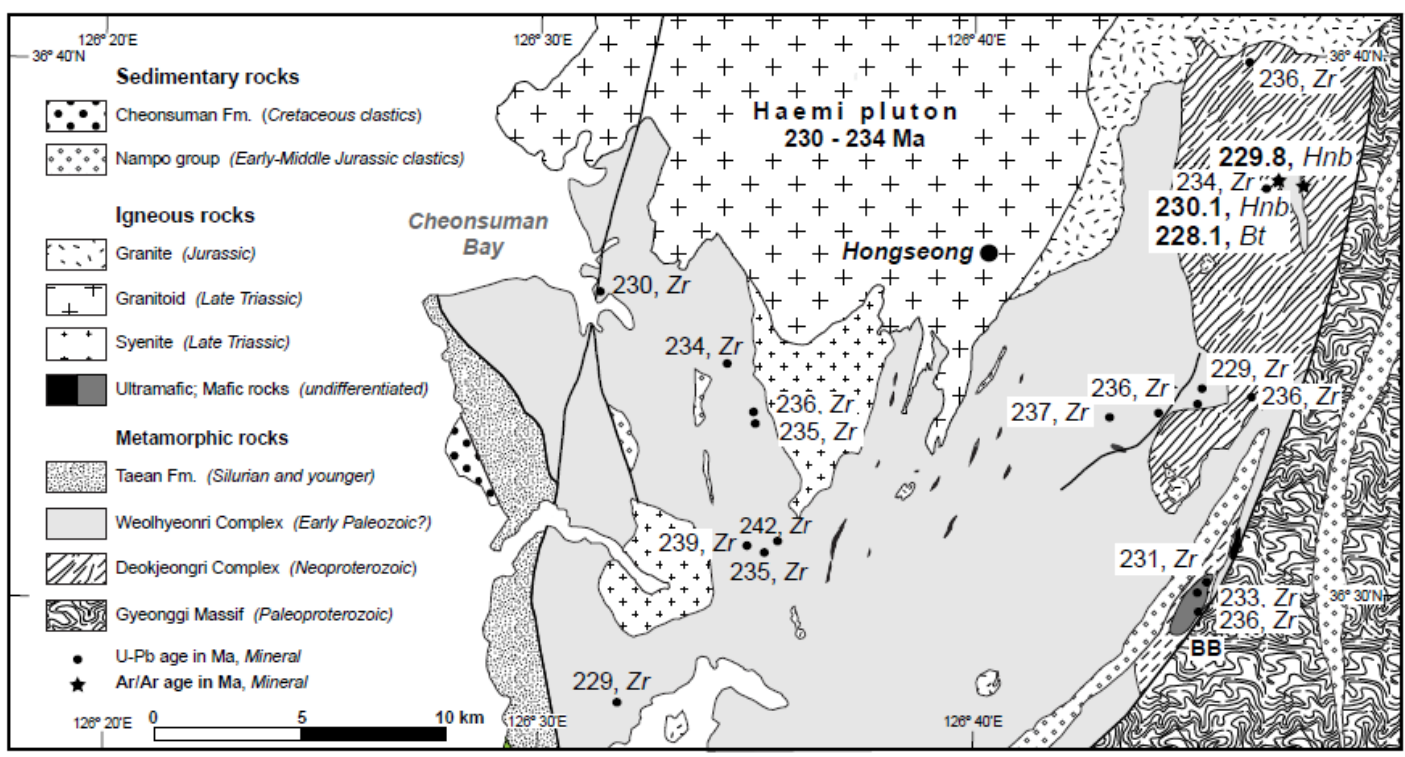

Figure 4.

Geological sketch map of the Hongseong area modified after Kee (2011), Kim et al. (2011b), de Jong and Ruffet (2014a):

mafic and ultra mafic rocks after Oh et al. (2014). Isotopic ages from Kee (2011) (U-Pb, zircon) and de Jong and Ruffet (2014a) (40Ar/39Ar). BB, Bibong. 

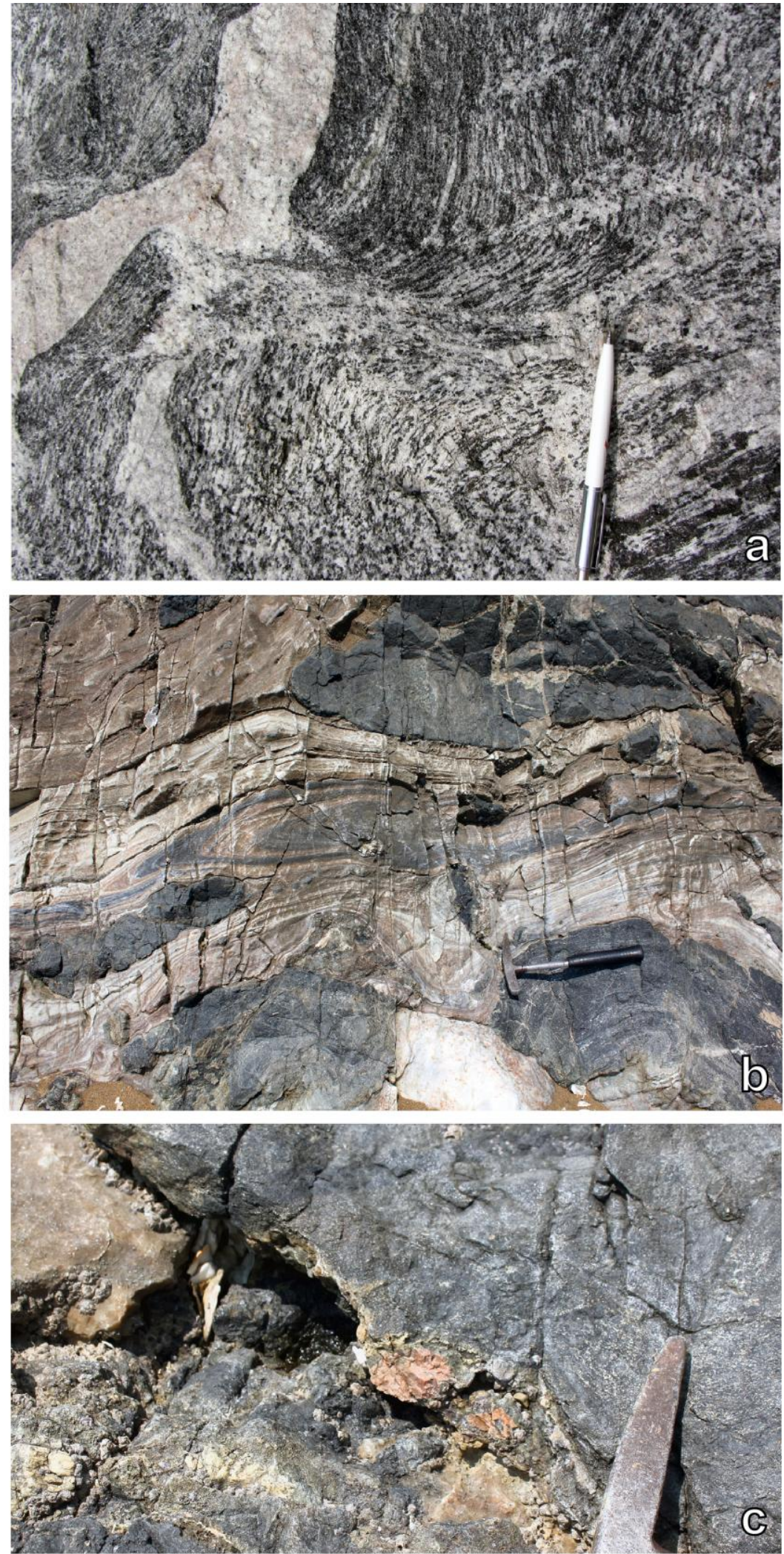

Figure 5 a-c. Field photographs

(a) Anatexis shown by irregular veins and patches along the main foliation and shear zones cut by irregular veins of fine-grained non-deformed granitic rocks, Hongseong area, (b) folded marble with mafic-ultramafic lenses that occur jointly with (c) fine-grained brick red siliceous layers/fine quartzites, Gonam Complex, Anmyeon Island.. 


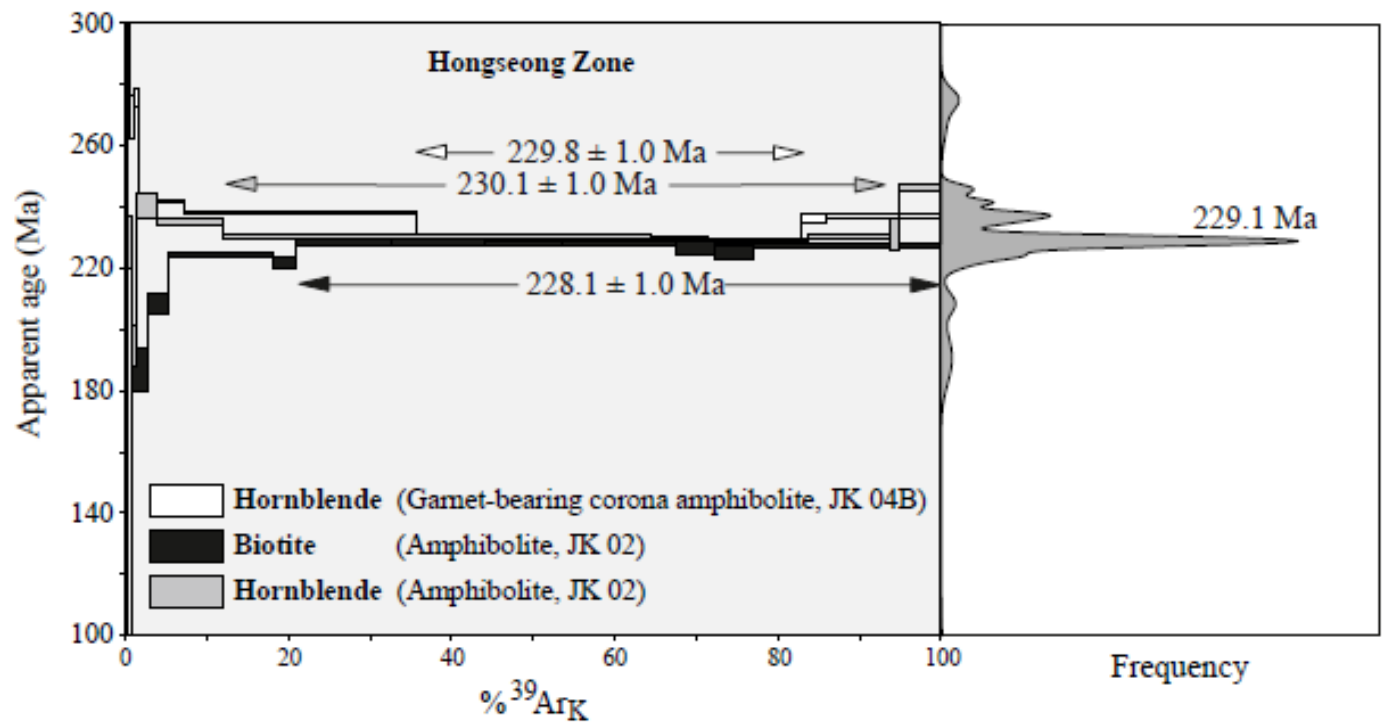

Figure 6

Step-heating age spectra of hornblende and biotite single grains from amphibolites in the Hongseong area, locations, see Fig. 4, and a corresponding relative frequency plot of all step ages, based on data from de Jong et al. (2014). Apparent age errors are plotted at the $1 \sigma$ level and do not include the errors on the $40 \mathrm{Ar}^{*} / 39 \mathrm{ArK}$ ratio and age of the monitor and decay constant. 


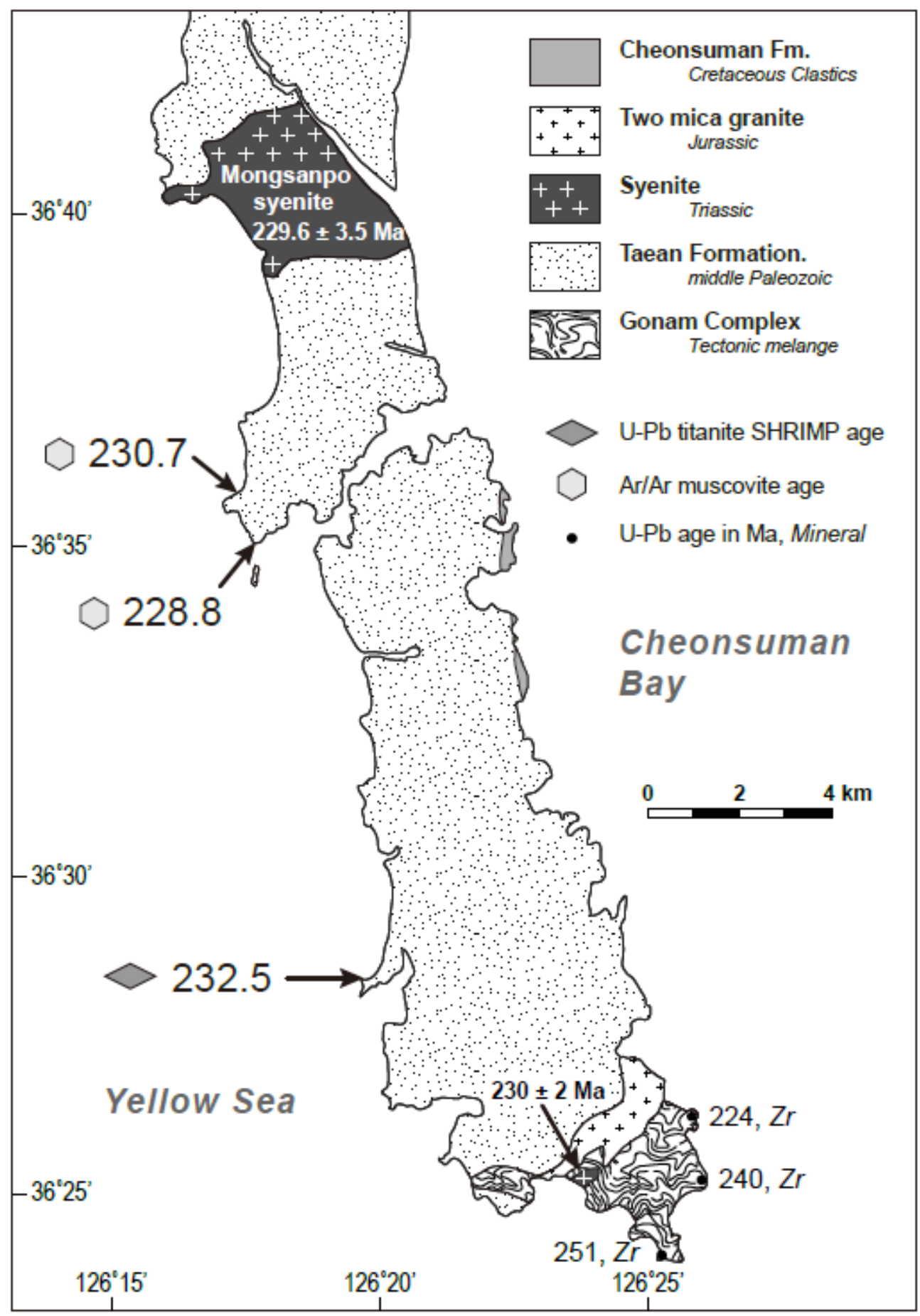

Figure 7.

Geological sketch map of Anmyeon Island based on Kee (2011), modified after de Jong et al. (2014). Isotopic ages from Kee (2011) (U-Pb, zircon) and de Jong et al. (2014) (40Ar/39Ar, mica; $\mathrm{U}-\mathrm{Pb}$, titanite). Age Mongsanpo syenite (SHRIMP U-Pb, zircon), after Han (2014); age intusive body in Gonam Complex from Kee (2011). 

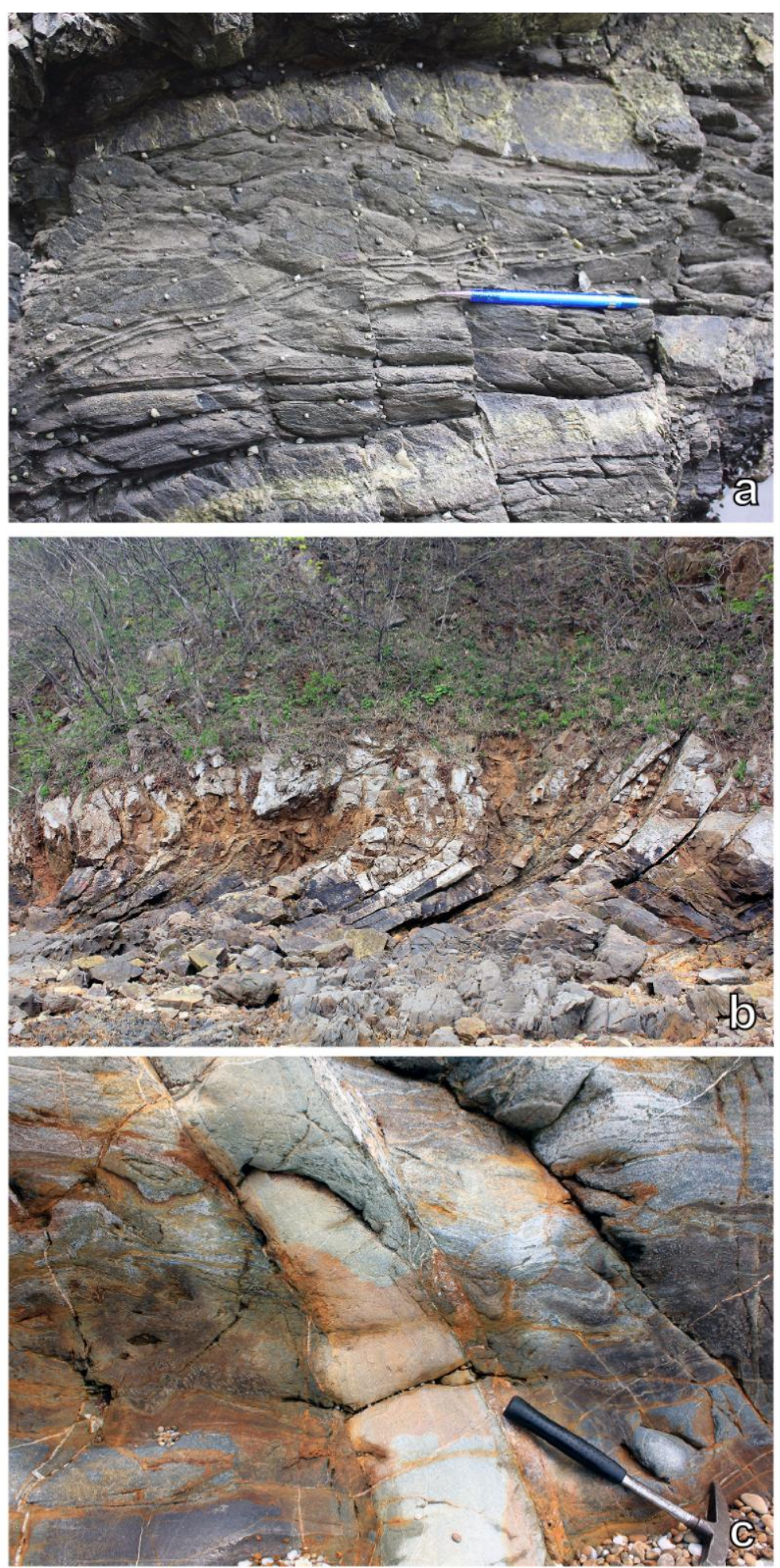

Figure 8 a-c. Field photographs Anmyeon Island (a) The earliest cleavage S1 is only locally developed in meta-pelites as the axial plane cleavage of rare recumbent tight to isoclinal folds; note the cross-cutting $\$ 2$, which also refracts on sandstone layers. (b) Megascopic open to tight disharmonic flexural slip F2 folds. (c) Curved but not folded mafic dyke truncates small-scale F2 folds and axial cleavage S2 (parallel to the hammer handle). 


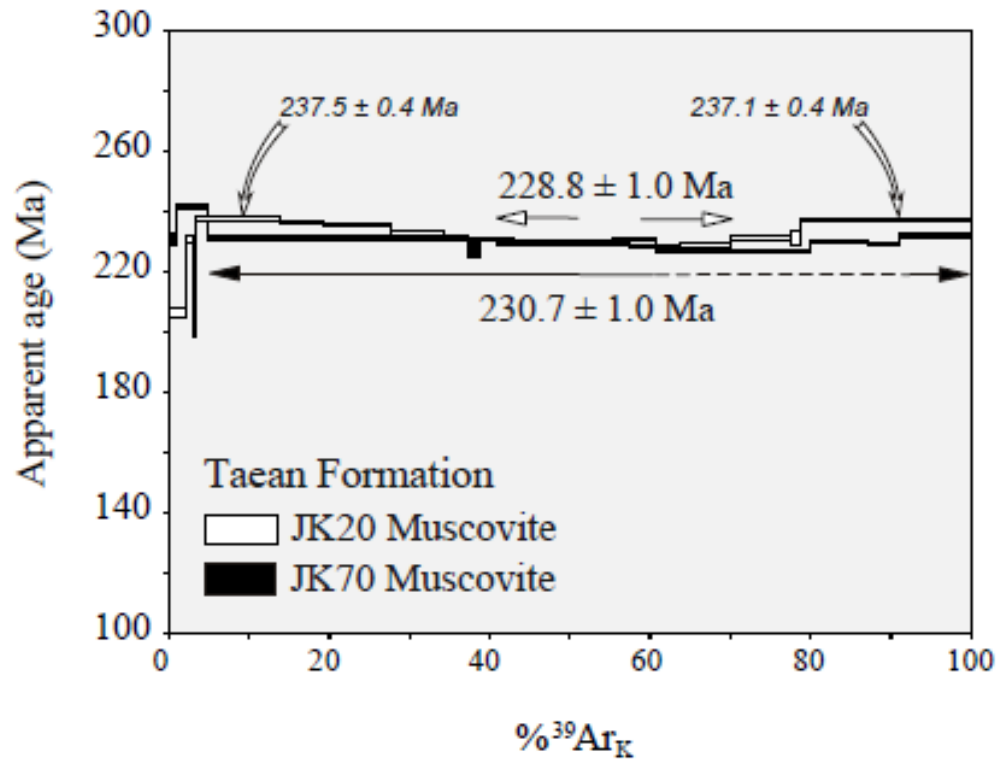

Figure 9

Step-heating age spectra of muscovite single grains from low-grade metapelites of the Taean Formation, Anmyeon Island (locations, Fig. 7), modified after de Jong et al. (2014).

Apparent age errors are plotted at the $1 \sigma$ level and do not include the errors on the $40 \mathrm{Ar}^{*} / 39 \mathrm{ArK}$ ratio and age of the monitor and decay constant 


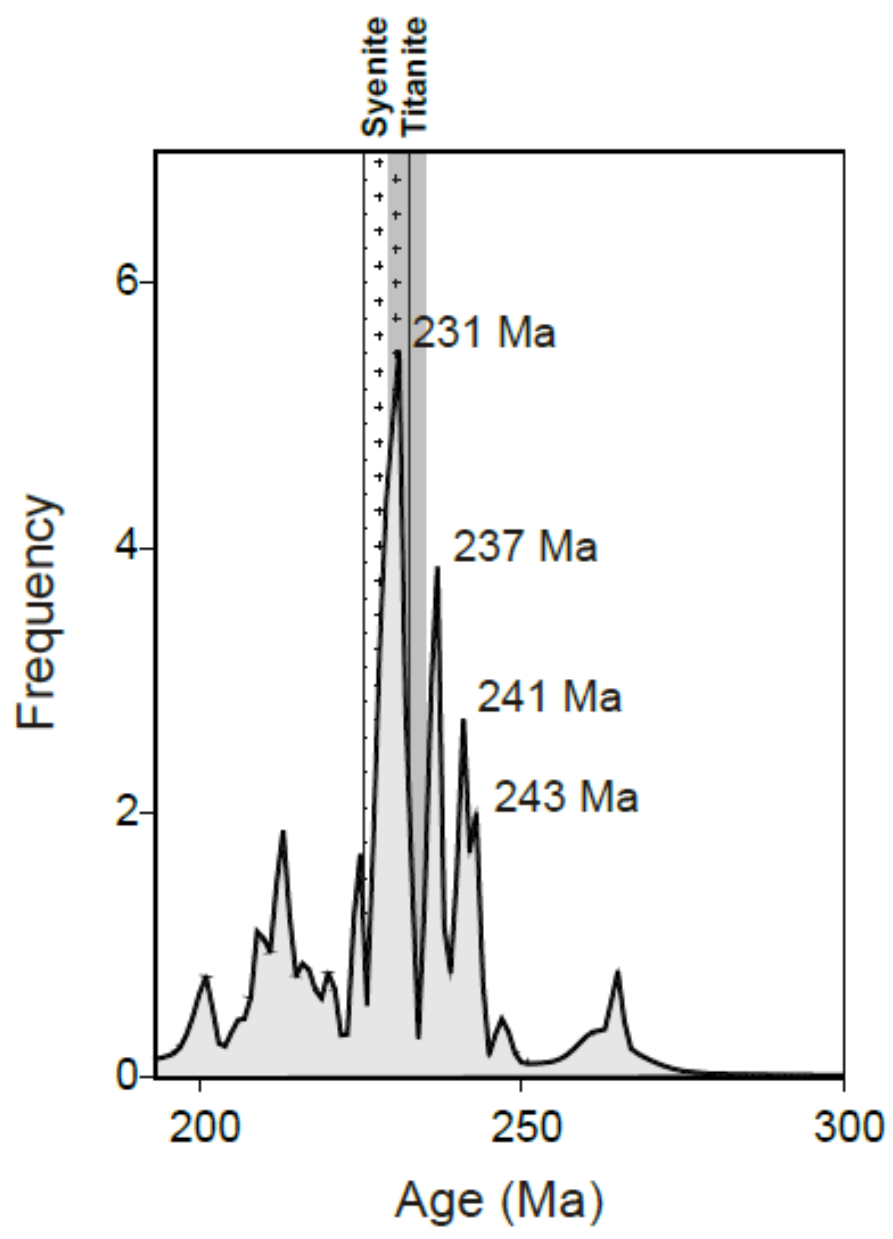

Figure 10

Relatively frequency plot of all age steps of muscovite samples $(\mathrm{N}=6)$, based on data from Han (2014). The ca. 237 Ma peak corresponds to the concordant low- and high-temperature steps in sample JK20 (Fig. 9). Titanite U-Pb age (232.5 $\pm 3.0 \mathrm{Ma}$ ) from de Jong et al. (2014); Mongsanpo syenite $(229.6 \pm 3.5 \mathrm{Ma}$, SHRIMP U-Pb, zircon) from Han (2014). 

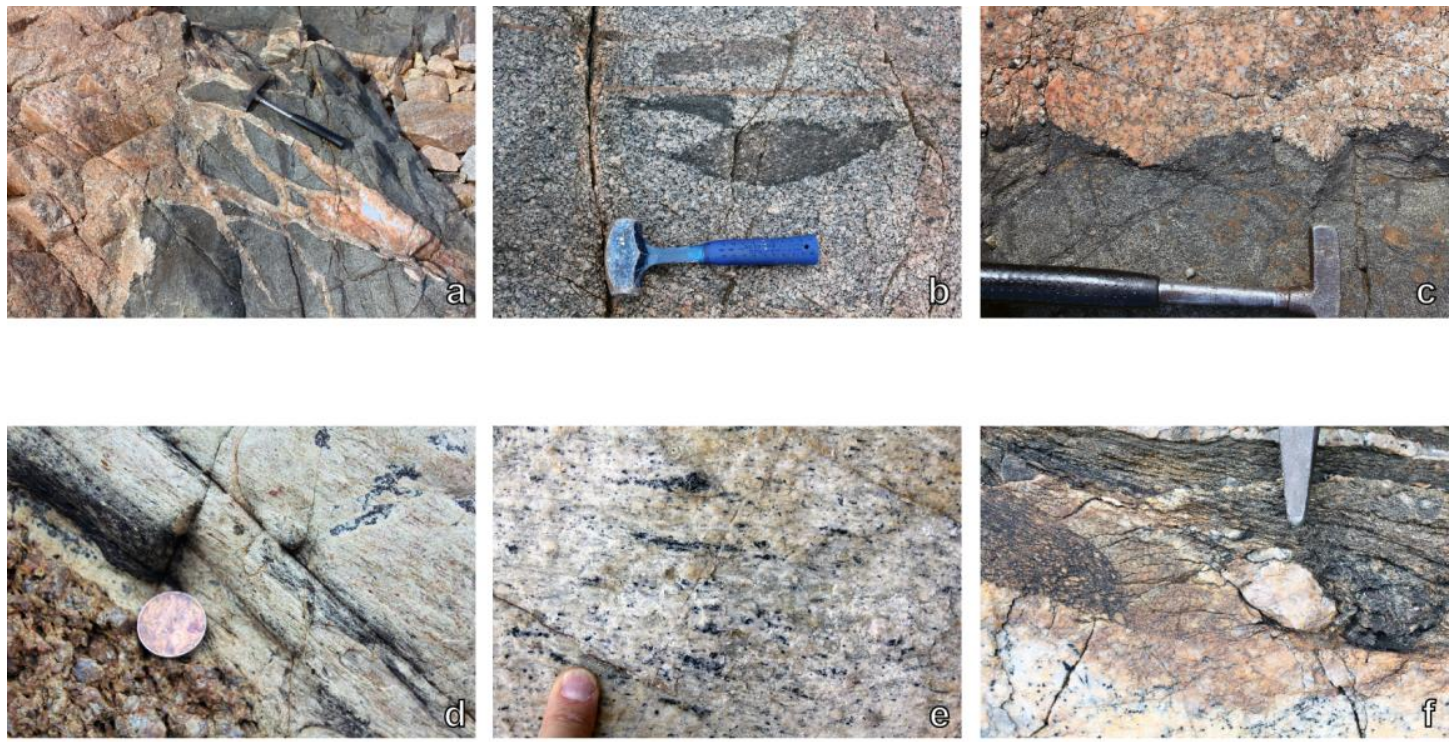

Figure 11 a-f.

a-c) Features attributable to mingling of syenite and mafic melts in the intrusive body at Mongsanpo. a) Flames of syenite invading mafic rocks. (b) Isolated pillow-like lobes of mafic enclaves define a preferred orientation in the syenite, note their darker and finer grained chilled margins. (c) Cuspate-concave contacts between syenite and mafic rock, suggesting (e) NNW-plunging stringers of extended tourmaline crystals in a ductilely deformed granitic rock with a mylonitic quartz-feldspar fabric, Gonam Complex, Anmyeon Island. (f) Boudin of tourmaline granite truncates the axial plane foliation of an F2 fold, looking Northward down-plunge and parallel to the earlier stretching lineation. Note the crenulation of the earlier S1 shear fabric in the F2 hinge zone, Gonam Complex, Anmyeon Island. 


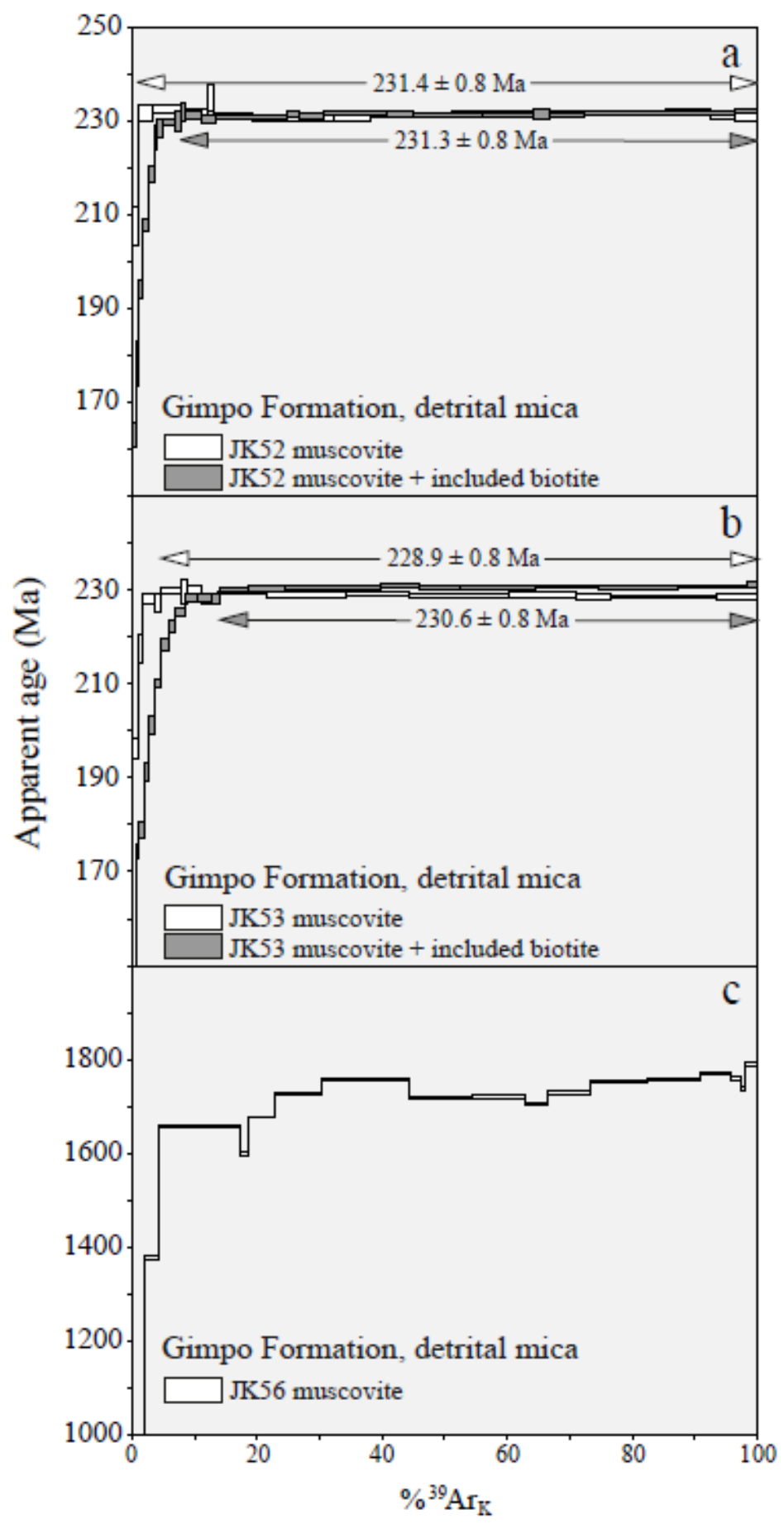

Figure 12 a-c.

Step-heating age spectra of detrital muscovites from sandstones of the Gimpo Group in the Juksung area (Fig. 2) (a) JK52, (b) JK53, (c) JK56. Apparent age errors are plotted at the $1 \sigma$ level and do not include the errors on the $40 \mathrm{Ar}^{*} / 39 \mathrm{ArK}$ ratio and age of the monitor and decay constant. 


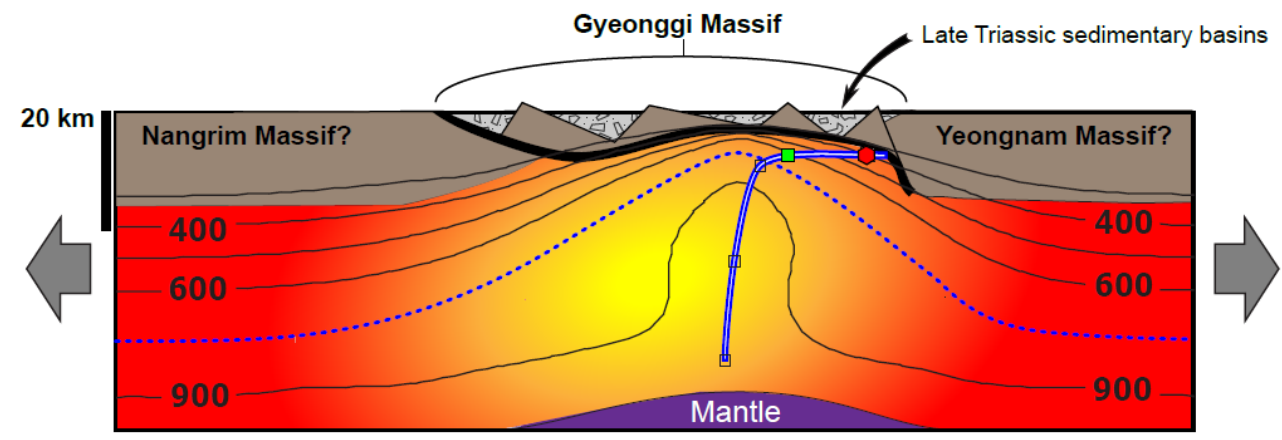

Figure 13

Cartoon section of a possible post-collisional configuration in the Korean tectonic system in the Late Triassic, showing a mantle upwarping, and resulting collapse of the isotherms over the extended and thinned region that coincides with the Gyeonggi Massif. Pre-stretching thickness of the brittle upper crust is about $18 \mathrm{~km}$. Isothermal surfaces in ${ }^{\circ} \mathrm{C}$. The particle path (double line) shows early near-isothermal decompression of the brittle upper crust is about $18 \mathrm{~km}$. Isothermal surfaces in ${ }^{\circ} \mathrm{C}$. The particle path (double line) shows early near-isothermal decompression
followed by fast cooling that takes over the thermal regime close to the detachment fault; polygon and square: approximate positions of biotite and hornblende closure, respectively. The dotted line represents the solidus, implying that magmatic rocks may be ductilely deformed during advanced exhumation and thinning, as is demonstrated by a number of Late Triassic intrusions in Anmyeon Island (Fig. 11 d-f). Modified after Rey et al. (2009) and Whitney et al. (2013). 
Graphical abstract

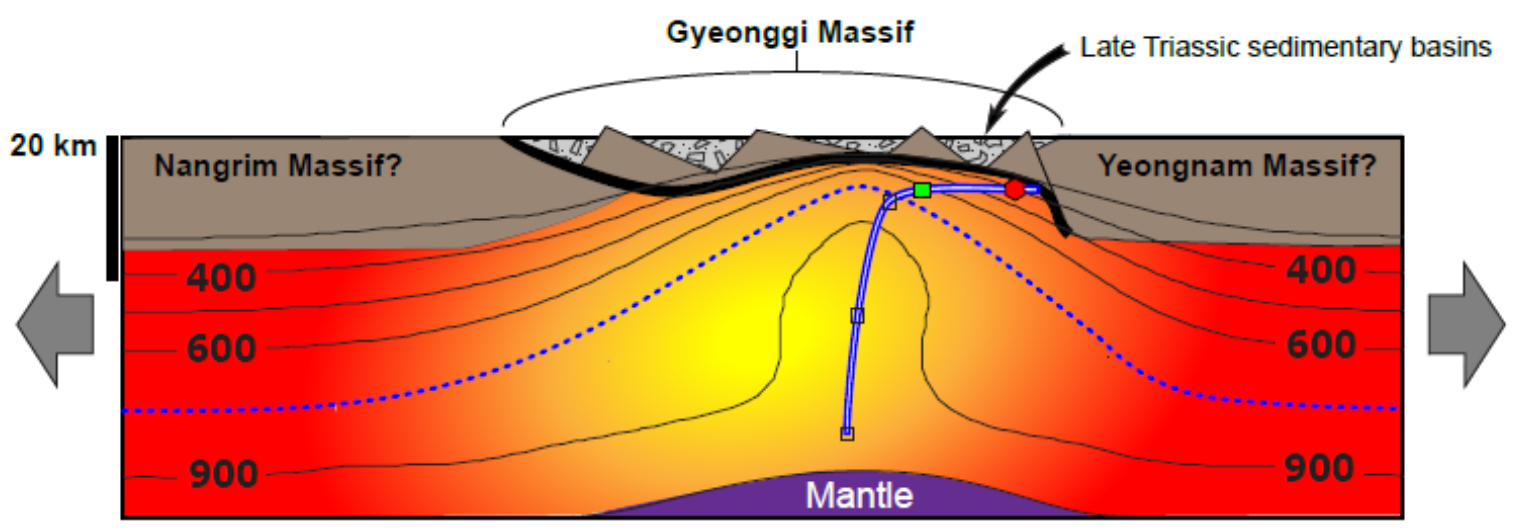

Figure 13.

Cartoon section of a possible post-collisional configuration in the Korean tectonic system in the Late Triassic, showing a mantle upwarping, and resulting collapse of the isotherms over the extended and thinned region that coincides with the Gyeonggi Massif. Pre-stretching thickness of the brittle upper crust is about $18 \mathrm{~km}$. Isothermal surfaces in ${ }^{\circ} \mathrm{C}$. The particle path (double line) shows early near-isothermal decompression followed by fast cooling that takes over the thermal regime close to the detachment fault; polygon and square: approximate positions of biotite and homblende closure, respectively. The dotted line represents the solidus, implying that magmatic rocks may be ductilely deformed during advanced exhumation and thinning, as is demonstrated by a number of Late Triassic intrusions in Anmyeon Island (Fig. $11 \mathrm{~d}-\mathrm{f}$ ). Modified after Rey et al. (2009) and Whitney et al. (2013). 
Table 1

\begin{tabular}{|c|c|c|c|c|c|c|c|c|c|c|c|c|c|c|c|c|}
\hline & & & & & & & & & & 8 & & & & & & \\
\hline & Title & $\mathrm{Nb}$ of steps & J parameter & $\pm \mathrm{J}$ & $\lambda\left(\mathrm{y}^{-1}\right)$ & $\pm \lambda\left(\mathrm{y}^{-1}\right)$ & Discrimination & \multicolumn{2}{|c|}{ \pm Discrimination } & 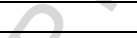 & & & & & & \\
\hline & 12JK52 muscovite & 15 & $6.03 \mathrm{E}-03$ & $1.65 \mathrm{E}-05$ & $5.53 \mathrm{E}-10$ & $1.35 \mathrm{E}-12$ & 1.008908 & \begin{tabular}{|l|l|}
$1.32 \mathrm{E}-03$ \\
\end{tabular} & & . & & & & & & \\
\hline Step & ${ }^{40} \mathrm{Ar}$ & $\pm^{40} \mathrm{Ar}$ & ${ }^{39} \mathrm{Ar}$ & $\pm{ }^{39} \mathrm{Ar}$ & ${ }^{38} \mathrm{Ar}$ & $\pm^{38} \mathrm{Ar}$ & ${ }^{37} \mathrm{Ar}$ & $\pm{ }^{37} \mathrm{Ar}$ & ${ }^{36} \mathrm{Ar}$ & $\pm{ }^{36} \mathrm{Ar}$ & ${ }^{40} \mathrm{Ar}^{*} /{ }^{39} \mathrm{Ar}_{\mathrm{K}}$ & $\pm^{40} \mathrm{Ar}^{*} /{ }^{39} \mathrm{Ar}_{\mathrm{K}}$ & age (Ma) & \pm Age (Ma) & $\%{ }^{39} \mathrm{Ar}$ & Atm. Cont. \\
\hline 1 & 352.228068 & 0.420043 & 14.395539 & 0.104829 & 0.236583 & 0.037202 & 0.013257 & $\begin{array}{l}0.037451 \\
\end{array}$ & 0.222533 & 0.018977 & 20.170229 & 0.414172 & 207.39 & 4.09 & $\begin{array}{r}0.89 \\
\end{array}$ & 17.45 \\
\hline 2 & \begin{tabular}{|l}
933.944433 \\
\end{tabular} & 0.690084 & 40.61112 & 0.110663 & 0.571688 & 0.036055 & 0.016315 & 0.037457 & 0.068242 & 0.02294 & 22.686353 & 0.179078 & 231.67 & 1.90 & 2.51 & 1.22 \\
\hline 3 & 1659.632009 & 0.875613 & 72.356005 & 0.115035 & 0.894387 & 0.031453 & 0.024647 & 0.039093 & 0.082037 & 0.021418 & 22.783899 & 0.099246 & 232.61 & 1.26 & 4.47 & 0.53 \\
\hline 4 & $\begin{array}{l}1521.4689 \\
\end{array}$ & 1.033914 & 67.0008 & 0.081508 & 0.7819 & 0.049358 & 0.000001 & $\begin{array}{l}0.03526 \\
\end{array}$ & 0.0416 & 0.018069 & 22.700607 & 0.089909 & 231.81 & 1.19 & 4.14 & 0.00 \\
\hline 5 & 403.759684 & 0.292825 & 17.595465 & 0.088138 & 0.161049 & 0.029562 & 0.000001 & 0.014641 & 0.006988 & 0.015941 & 23.005698 & 0.289285 & 234.73 & 2.89 & 1.09 & 0.00 \\
\hline 6 & 2266.876438 & 1.235198 & 100.6363 & 0.118514 & 1.239322 & 0.055441 & 0.000001 & $\begin{array}{ll}0.02603 \\
\end{array}$ & 0.029132 & 0.023421 & 22.612714 & 0.079586 & 230.97 & 1.12 & 6.22 & 0.00 \\
\hline 7 & 2877.81227 & 1.224469 & 128.10101 & 0.229333 & 1.558858 & 0.064502 & 0.000001 & 0.018332 & 0.025638 & 0.021005 & 22.57792 & 0.069889 & 230.63 & 1.06 & 7.92 & 0.00 \\
\hline 8 & 1863.826576 & 0.785475 & 82.514606 & 0.150469 & 1.017864 & 0.04731 & 0.000972 & 0.016557 & 0.058293 & 0.014385 & 22.554572 & 0.072679 & 230.41 & 1.07 & 5.10 & 0.01 \\
\hline 9 & 2080.39263 & 1.25273 & 92.383917 & 0.149588 & 1.104311 & 0.041271 & 0.017592 & 0.018981 & 0.041275 & 0.015506 & 22.561381 & 0.069353 & 230.48 & 1.05 & 5.71 & 0.00 \\
\hline 10 & 4810.34471 & 2.577919 & 213.17234 & 0.171377 & 2.68966 & 0.070926 & 0.037176 & 0.017632 & 0.066532 & 0.01388 & 22.647364 & 0.041799 & 231.30 & 0.91 & 13.18 & 0.00 \\
\hline 11 & 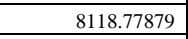 & 2.639896 & 360.08711 & 0.496376 & 4.463243 & 0.097525 & 0.096648 & 0.031685 & 0.059017 & 0.015604 & 22.671852 & 0.045674 & 231.53 & 0.93 & 22.26 & 0.00 \\
\hline 12 & 4293.131035 & 1.169017 & 190.4884 & 0.176628 & 2.357669 & 0.036603 & 0.036483 & 0.022771 & 0.006576 & 0.014538 & 22.69977 & 0.043136 & 231.80 & 0.92 & 11.77 & 0.00 \\
\hline 13 & 2605.916701 & 1.805128 & 115.42224 & 0.202905 & 1.465123 & 0.040606 & 0.000001 & 0.029466 & 0.020839 & 0.01494 & 22.69657 & 0.064441 & 231.77 & 1.03 & 7.13 & 0.00 \\
\hline 14 & 1454.839795 & 0.893405 & 64.526981 & 0.077177 & 0.803337 & 0.032227 & 0.000001 & 0.024672 & 0.021359 & 0.01841 & 22.621589 & 0.093276 & 231.05 & 1.21 & 3.99 & 0.00 \\
\hline \multirow[t]{4}{*}{ fusion } & 1316.942559 & 0.920609 & 58.469049 & 0.175597 & 0.690455 & 0.049888 & 0.045806 & 0.020672 & 0.018257 & 0.017356 & 22.607926 & 0.114845 & 230.92 & 1.37 & 3.61 & 0.00 \\
\hline & & & & & & & 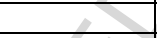 & & & & & & & & & \\
\hline & Title & $\mathrm{Nb}$ of steps & J parameter & $\pm \mathrm{J}$ & $\lambda\left(\mathrm{y}^{-1}\right)$ & $\pm \lambda\left(\mathrm{y}^{-1}\right)$ & $\begin{array}{l}\text { Discrimination } \\
\end{array}$ & \multicolumn{2}{|c|}{ \pm Discrimination } & & & & & & & \\
\hline & $12 \mathrm{JK} 52$ musc+biot & 23 & $6.03 \mathrm{E}-03$ & $1.65 \mathrm{E}-05$ & $5.53 \mathrm{E}-10$ & $1.35 \mathrm{E}-12$ & 1.008908 & \begin{tabular}{|l|l|}
$1.32 \mathrm{E}-03$ \\
\end{tabular} & & & & & & & & \\
\hline Step & ${ }^{40} \mathrm{Ar}$ & $\pm{ }^{40} \mathrm{Ar}$ & ${ }^{39} \mathrm{Ar}$ & $\pm{ }^{39} \mathrm{Ar}$ & ${ }^{38} \mathrm{Ar}$ & $\pm^{38} \mathrm{Ar}$ & ${ }^{37} \mathbf{A r}$ & $\pm{ }^{37} \mathrm{Ar}$ & ${ }^{36} \mathrm{Ar}$ & $\pm{ }^{36} \mathrm{Ar}$ & ${ }^{40} \mathrm{Ar}^{*{ }^{39}} \mathrm{Ar}_{\mathrm{K}}$ & $\pm^{40} \mathrm{Ar}^{* \beta^{39}} \mathrm{Ar}_{\mathrm{K}}$ & age (Ma) & \pm Age (Ma) & $\%{ }^{39} \mathrm{Ar}$ & Atm. Cont. \\
\hline 1 & 1004.960636 & 0.606844 & 32.194278 & 0.105498 & 0.774998 & 0.034755 & 0.031016 & $\begin{array}{l}0.027751 \\
\end{array}$ & 1.751745 & 0.023294 & 15.65999 & 0.24046 & 163.04 & 2.46 & $\begin{array}{l}0.79 \\
\end{array}$ & 49.76 \\
\hline 2 & 169.706 & 0.26312 & 8.316269 & 0.052337 & 0.124889 & 0.025 & 0.026611 & 0.023589 & 0.09696 & 0.012991 & 17.191102 & 0.469295 & 178.22 & 4.68 & 0.20 & 15.65 \\
\hline 3 & \begin{tabular}{|l|}
534.048329 \\
\end{tabular} & 0.648037 & 27.124616 & 0.089381 & 0.350525 & 0.029867 & 0.036988 & 0.021275 & 0.096686 & 0.0168 & 18.809608 & 0.194098 & 194.13 & 2.02 & 0.66 & 4.34 \\
\hline 4 & 851.008299 & 0.466541 & 40.389651 & 0.087886 & 0.543521 & 0.034456 & 0.031616 & 0.027344 & 0.141051 & 0.016888 & 20.219815 & 0.133524 & 207.88 & 1.49 & 0.99 & 3.91 \\
\hline 5 & 770.407295 & 0.535708 & 35.647834 & 0.142212 & 0.440546 & 0.036945 & 0.017813 & 0.026948 & 0.056956 & 0.020679 & 21.314267 & 0.191697 & 218.47 & 2.01 & 0.87 & 1.24 \\
\hline 6 & \begin{tabular}{|l|}
334.32742 \\
\end{tabular} & 0.225519 & 14.540738 & 0.045954 & 0.158049 & 0.02991 & 0.020464 & 0.029246 & 0.052479 & 0.012899 & 22.125773 & 0.26972 & 226.29 & 2.71 & 0.35 & 3.64 \\
\hline 7 & 902.086538 & 0.321931 & 39.457953 & 0.103413 & 0.524609 & 0.035555 & 0.014746 & 0.03491 & 0.095468 & 0.025749 & 22.335086 & 0.201229 & 228.30 & 2.10 & 0.96 & 2.17 \\
\hline 8 & 1975.282669 & 1.255577 & 87.353959 & 0.103273 & 1.079779 & 0.033497 & 0.009481 & 0.02799 & 0.09367 & 0.019702 & 22.473413 & 0.078564 & 229.63 & 1.11 & 2.13 & 0.48 \\
\hline 9 & 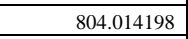 & 0.659645 & 34.987739 & 0.177903 & 0.404834 & 0.036235 & 0.000001 & 0.018521 & 0.078397 & 0.021299 & 22.503852 & 0.2139 & 229.92 & 2.21 & 0.85 & 1.94 \\
\hline 10 & 712.062549 & 0.692162 & 31.450531 & 0.094495 & 0.401388 & 0.021117 & 0.000001 & 0.030891 & 0.014014 & 0.021078 & 22.68344 & 0.209613 & 231.65 & 2.17 & 0.77 & 0.00 \\
\hline 11 & 2256.864094 & 0.941453 & 98.370254 & 0.247626 & 1.183053 & 0.040322 & 0.000001 & 0.024942 & 0.162084 & 0.018695 & 22.638454 & 0.086112 & 231.21 & 1.16 & 2.40 & 1.19 \\
\hline 12 & 2183.318032 & 1.201626 & 96.855897 & 0.26241 & 1.18573 & 0.033702 & 0.036705 & 0.026595 & 0.06194 & 0.015047 & 22.529316 & 0.082707 & 230.17 & 1.14 & 2.36 & 0.00 \\
\hline 13 & \begin{tabular}{|l|}
10591.29951 \\
\end{tabular} & 2.54588 & \begin{tabular}{|l|l|}
460.74773 \\
\end{tabular} & 0.529412 & 5.982881 & 0.114666 & 0.070499 & 0.026164 & 0.925239 & 0.017584 & 22.579616 & 0.043501 & 230.65 & 0.92 & 11.24 & 1.64 \\
\hline 14 & 2144.468332 & 1.413726 & 94.917297 & 0.095919 & 1.22053 & 0.033009 & 0.016705 & 0.028557 & 0.03224 & 0.017492 & 22.666965 & 0.067293 & 231.49 & 1.04 & 2.32 & 0.00 \\
\hline 15 & 3438.546216 & 1.734061 & 151.42581 & 0.221105 & 1.952881 & 0.060173 & 0.041608 & 0.026727 & 0.139488 & 0.017257 & 22.614247 & 0.057279 & 230.98 & 0.99 & 3.70 & 0.28 \\
\hline 16 & 9548.473198 & 2.388592 & 421.91429 & 0.20467 & 5.292636 & 0.045796 & 0.037631 & 0.016169 & 0.18115 & 0.008524 & 22.679054 & 0.03334 & 231.60 & 0.88 & 10.30 & 0.00 \\
\hline 17 & 3823.606279 & 1.780127 & 167.37698 & 0.098909 & 2.032298 & 0.039566 & 0.040882 & 0.020452 & 0.21652 & 0.024835 & 22.643323 & 0.056144 & 231.26 & 0.98 & 4.08 & 0.74 \\
\hline 18 & 10186.77531 & 2.199705 & 452.32125 & 0.317185 & 5.626084 & 0.071139 & 0.082018 & \begin{tabular}{|l|l|}
0.019387 \\
\end{tabular} & 0.080265 & 0.012013 & 22.641492 & 0.035109 & 231.24 & 0.89 & 11.04 & 0.00 \\
\hline 19 & 7454.357299 & 2.050219 & 330.68314 & 0.497896 & 3.984237 & 0.069469 & 0.120903 & 0.023249 & 0.10003 & 0.013733 & 22.627377 & 0.047436 & 231.11 & 0.94 & 8.07 & 0.00 \\
\hline 20 & 2424.597379 & 0.832755 & 105.55298 & 0.447234 & 1.325998 & 0.060597 & 0.047182 & 0.027204 & 0.18302 & 0.015903 & 22.643603 & 0.11048 & 231.26 & 1.34 & 2.58 & 1.29 \\
\hline 21 & 5220.542451 & 1.80719 & 231.65284 & 0.234724 & 3.003635 & 0.075614 & 0.019712 & 0.02337 & 0.066526 & 0.015549 & 22.624282 & 0.043272 & 231.08 & 0.92 & 5.65 & 0.00 \\
\hline 22 & 22344.71437 & 7.053859 & 991.61214 & 0.835321 & 12.504033 & 0.178907 & 0.078514 & 0.020243 & 0.117511 & 0.015822 & 22.670832 & 0.036487 & 231.52 & 0.89 & 24.20 & 0.00 \\
\hline
\end{tabular}




\begin{tabular}{|c|c|c|c|c|c|c|c|c|c|c|c|c|c|c|c|c|}
\hline fusion & 3227.932766 & 1.059705 & 142.47274 & 0.165617 & 1.754633 & 0.092484 & 0.062914 & 0.012295 & 0.056611 & 0.017157 & 22.71529 & 0.053832 & 231.95 & 0.97 & 3.48 & 0.00 \\
\hline & & & & & & & & & & & & & & & & \\
\hline & Title & $\mathrm{Nb}$ of steps & J parameter & $\pm \mathrm{J}$ & $\lambda\left(y^{-1}\right)$ & $\pm \lambda\left(y^{-1}\right)$ & Discrimination & \multicolumn{2}{|c|}{ \pm Discrimination } & 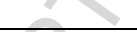 & & & & & & \\
\hline & 12JK53 muscovite & 16 & $6.04 \mathrm{E}-03$ & $1.66 \mathrm{E}-05$ & $5.53 \mathrm{E}-10$ & \begin{tabular}{|l|}
$1.35 \mathrm{E}-12$ \\
\end{tabular} & \begin{tabular}{|l|}
1.008908 \\
\end{tabular} & $1.32 \mathrm{E}-03$ & & 20 & & & & & & \\
\hline Step & ${ }^{40} \mathrm{Ar}$ & $\pm{ }^{40} \mathrm{Ar}$ & ${ }^{39} \mathrm{Ar}$ & $\pm{ }^{39} \mathrm{Ar}$ & \begin{tabular}{|l|}
${ }^{38} \mathrm{Ar}$ \\
\end{tabular} & $\pm{ }^{38} \mathrm{Ar}$ & ${ }^{37} \mathrm{Ar}$ & $\pm{ }^{37} \mathrm{Ar}$ & ${ }^{36} \mathrm{Ar}$ & $\pm^{36} \mathrm{Ar}$ & ${ }^{40} \mathrm{Ar}^{* / 30} \mathrm{Ar}_{\mathrm{K}}$ & $\pm^{40} \mathrm{Ar}^{*} \beta^{\beta 9} \mathrm{~A} \mathbf{r}_{\mathrm{K}}$ & age (Ma) & \pm Age (Ma) & $\%{ }^{39} \mathrm{Ar}$ & Atm. Cont. \\
\hline 1 & 570.241714 & 0.759958 & 25.386178 & 0.09687 & 0.391354 & 0.026284 & 0.000001 & \begin{tabular}{|l|l|}
0.024426 \\
\end{tabular} & 0.318058 & \begin{tabular}{|l}
0.018473 \\
\end{tabular} & \begin{tabular}{|l|}
18.995821 \\
\end{tabular} & 0.229667 & 196.31 & 2.36 & 1.01 & 15.32 \\
\hline 2 & 371.943122 & 0.352409 & 16.632062 & 0.090151 & 0.258491 & 0.036763 & 0.000001 & 0.011732 & 0.077974 & 0.017898 & 21.171943 & 0.335338 & 217.50 & 3.34 & 0.66 & 5.20 \\
\hline 3 & 1077.940802 & 0.568127 & 46.975941 & 0.087668 & 0.540027 & 0.044597 & 0.000001 & 0.029751 & 0.137788 & 0.017874 & 22.269154 & 0.123364 & 228.09 & 1.44 & 1.87 & 2.82 \\
\hline 4 & $\begin{array}{l}551.499632 \\
\end{array}$ & 0.264674 & 24.100123 & 0.084527 & 0.364803 & 0.036901 & 0.000001 & 0.017564 & 0.071883 & 0.01624 & 22.191721 & 0.213521 & 227.34 & 2.21 & 0.96 & 2.89 \\
\hline 5 & 1885.087767 & 1.227246 & 82.848497 & 0.189674 & 1.002293 & 0.031353 & 0.005527 & 0.017763 & 0.136791 & 0.018438 & 22.447086 & 0.089747 & 229.80 & 1.19 & 3.30 & 1.21 \\
\hline 6 & $\begin{array}{r}510.560228 \\
\end{array}$ & 0.448448 & 22.383516 & 0.074557 & 0.255881 & 0.025557 & 0.000001 & 0.02032 & 0.04381 & 0.020482 & 22.414445 & 0.278612 & 229.49 & 2.80 & 0.89 & 1.60 \\
\hline 7 & 1466.361501 & 0.662189 & 65.192128 & 0.138315 & 0.794026 & 0.027981 & 0.000001 & 0.019791 & 0.04756 & 0.017761 & 22.451848 & 0.097781 & 229.85 & 1.24 & 2.60 & 0.04 \\
\hline 8 & 1388.6676 & 0.669279 & 62.6023 & 0.122891 & 0.71 & 0.040893 & 0.0005 & 0.021472 & 0.0152 & 0.024071 & 22.280198 & 0.123961 & 228.20 & 1.44 & 2.49 & 0.00 \\
\hline 9 & 4227.6862 & 1.706064 & 189.4152 & 0.117374 & 2.4144 & 0.077911 & 0.0189 & 0.034318 & 0.0517 & 0.019486 & 22.410389 & 0.045343 & 229.45 & 0.92 & 7.54 & 0.00 \\
\hline 10 & 7202.376874 & 3.357468 & 323.22078 & 0.51087 & 3.951606 & 0.0713 & 0.089913 & 0.022126 & 0.100667 & 0.023842 & 22.363132 & 0.051987 & 228.99 & 0.95 & 12.87 & 0.00 \\
\hline 11 & 5667.365922 & 3.061676 & 254.21458 & 0.184671 & 3.198001 & 0.028911 & 0.048626 & 0.014187 & 0.083326 & 0.02401 & 22.368563 & 0.045306 & 229.05 & 0.92 & 10.12 & 0.00 \\
\hline 12 & 8967.35105 & 2.945643 & 402.60183 & 0.328118 & 4.86981 & 0.066695 & 0.160929 & 0.025677 & 0.153028 & 0.022597 & 22.334051 & 0.039273 & 228.71 & 0.90 & 16.03 & 0.00 \\
\hline 13 & $\begin{array}{l}6036.174463 \\
\end{array}$ & 2.137576 & 270.03588 & 0.34269 & 3.370151 & 0.073202 & 0.000761 & 0.01984 & 0.148048 & 0.019292 & 22.363658 & 0.046982 & 229.00 & 0.93 & 10.75 & 0.00 \\
\hline 14 & 3112.735879 & 1.335461 & 139.40827 & 0.257471 & 1.765444 & 0.081887 & 0.012861 & 0.023262 & 0.079268 & 0.023586 & 22.332984 & 0.071506 & 228.70 & 1.06 & 5.55 & 0.00 \\
\hline 15 & 9319.708326 & 3.345235 & 419.35236 & 0.305251 & 5.203462 & 0.081059 & 0.072903 & 0.018244 & 0.121119 & 0.020414 & 22.309645 & 0.037541 & 228.48 & 0.89 & 16.70 & 0.00 \\
\hline \multirow[t]{4}{*}{ fusion } & $\begin{array}{l}3703.30349 \\
\end{array}$ & 3.291695 & 166.51849 & 0.142839 & 2.149861 & 0.059121 & 0.039823 & 0.018692 & 0.053923 & 0.020973 & 22.315516 & 0.054638 & 228.54 & 0.97 & 6.63 & 0.00 \\
\hline & & & & & & & 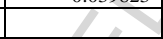 & & & & & & & & & \\
\hline & Title & $\mathrm{Nb}$ of steps & J parameter & $\pm \mathrm{J}$ & $\lambda\left(y^{-1}\right)$ & $\pm \lambda\left(\mathrm{y}^{-1}\right)$ & Discrimination & \multicolumn{2}{|c|}{ \pm Discrimination } & & & & & & & \\
\hline & $12 \mathrm{JK} 53 \mathrm{musc}+\mathrm{biot}$ & 22 & $6.04 \mathrm{E}-03$ & $1.66 \mathrm{E}-05$ & \begin{tabular}{|l|}
$5.53 \mathrm{E}-10$ \\
\end{tabular} & $1.35 \mathrm{E}-12$ & \begin{tabular}{|l|}
1.008908 \\
\end{tabular} & \begin{tabular}{|l|}
$1.32 \mathrm{E}-03$ \\
\end{tabular} & & & & & & & & \\
\hline Step & ${ }^{40} \mathrm{Ar}$ & $\pm^{ \pm 0} \mathrm{Ar}$ & \begin{tabular}{|l|}
${ }^{39} \mathrm{Ar}$ \\
\end{tabular} & $\pm{ }^{39} \mathrm{Ar}$ & \begin{tabular}{|l|}
${ }^{38} \mathrm{Ar}$ \\
\end{tabular} & $\pm{ }^{38} \mathrm{Ar}$ & \begin{tabular}{|l|l|}
${ }^{37} \mathrm{Ar}$ \\
\end{tabular} & $\pm{ }^{37} \mathrm{Ar}$ & ${ }^{36} \mathrm{Ar}$ & $\pm{ }^{36} \mathrm{Ar}$ & ${ }^{40} \mathrm{Ar}^{*} /{ }^{39} \mathrm{Ar}_{\mathrm{K}}$ & $\pm^{40} \mathbf{A r}^{*} /{ }^{39} \mathbf{A r}_{\mathrm{K}}$ & age (Ma) & \pm Age (Ma) & $\%{ }^{39} \mathrm{Ar}$ & Atm. Cont. \\
\hline 1 & 1138.686804 & 0.674705 & 24.247154 & 0.097171 & 0.812066 & 0.040595 & 0.011139 & $\begin{array}{l}0.024899 \\
\end{array}$ & 2.857576 & 0.019774 & 13.104743 & 0.313461 & 137.68 & 3.21 & 0.59 & 72.06 \\
\hline 2 & 461.131169 & 0.377896 & 23.450881 & 0.09318 & 0.370797 & 0.034322 & 0.017168 & 0.021899 & 0.245512 & 0.010558 & 16.776783 & 0.15246 & 174.45 & 1.63 & 0.57 & 14.56 \\
\hline 3 & 571.564976 & 0.395097 & 30.350904 & 0.083772 & 0.403175 & 0.044383 & 0.000001 & 0.026437 & 0.18393 & 0.017994 & 17.214862 & 0.181893 & 178.79 & 1.91 & 0.74 & 8.46 \\
\hline 4 & 688.371071 & 0.587026 & 34.235065 & 0.102166 & 0.406469 & 0.037659 & 0.012587 & 0.023687 & 0.209882 & 0.019248 & 18.481085 & 0.176407 & 191.27 & 1.86 & 0.84 & 7.96 \\
\hline 5 & $\begin{array}{l}602.178315 \\
\end{array}$ & 0.538324 & 28.638373 & 0.057262 & 0.414716 & $\begin{array}{l}0.039636 \\
\end{array}$ & 0.012315 & 0.038305 & 0.166929 & 0.019731 & 19.496088 & 0.207658 & 201.21 & 2.15 & 0.70 & 7.15 \\
\hline 6 & 1356.824588 & 0.808174 & 51.877713 & 0.081061 & 0.904284 & 0.033571 & 0.017312 & 0.027088 & 1.061894 & 0.014765 & 20.411477 & 0.107006 & 210.13 & 1.28 & 1.27 & 21.85 \\
\hline 7 & 1220.972729 & 1.111445 & 50.503388 & 0.141081 & 0.791785 & 0.036945 & 0.01875 & 0.031603 & 0.540842 & 0.016348 & 21.252023 & 0.12166 & 218.28 & 1.41 & 1.24 & 11.97 \\
\hline 8 & 771.37922 & 0.447981 & 33.924387 & 0.086704 & 0.416671 & 0.021973 & 0.02388 & 0.043242 & 0.144681 & 0.013514 & 21.675622 & 0.133714 & 222.37 & 1.51 & 0.83 & 4.54 \\
\hline 9 & 1487.150864 & 0.564298 & 64.617264 & 0.087467 & 0.779783 & 0.05031 & 0.028905 & 0.022842 & 0.269682 & 0.014542 & 21.979441 & 0.080438 & 225.30 & 1.11 & 1.58 & 4.37 \\
\hline 10 & 2122.885458 & 0.713589 & 93.206102 & 0.29786 & 1.15852 & 0.030493 & 0.000001 & 0.019125 & 0.211559 & 0.017621 & 22.289565 & 0.095931 & 228.29 & 1.23 & 2.28 & 2.00 \\
\hline 11 & 2062.695362 & 1.391312 & 91.337418 & 0.124511 & 1.149398 & 0.069431 & 0.054778 & 0.023172 & 0.147524 & 0.025771 & 22.28831 & 0.094196 & 228.27 & 1.22 & 2.24 & 1.17 \\
\hline 12 & 1177.202375 & 0.773533 & 52.312754 & 0.052451 & 0.610798 & 0.02346 & 0.032712 & 0.017015 & 0.072038 & 0.016663 & 22.276776 & 0.101268 & 228.16 & 1.27 & 1.28 & 0.87 \\
\hline 13 & 4098.3632 & 1.275572 & $\begin{array}{l}181.3967 \\
\end{array}$ & 0.123451 & 2.2108 & 0.066306 & 0.0178 & 0.018883 & 0.191 & 0.017824 & 22.459078 & 0.045408 & 229.92 & 0.93 & 4.45 & 0.45 \\
\hline 14 & $\begin{array}{l}5488.044081 \\
\end{array}$ & 3.330463 & 242.912 & 0.300407 & 3.073986 & 0.058432 & 0.065035 & 0.023719 & 0.217258 & 0.01452 & 22.505398 & 0.047097 & 230.36 & 0.93 & 5.95 & 0.25 \\
\hline 15 & $\begin{array}{l}13889.8486 \\
\end{array}$ & 5.84663 & 615.3849 & 0.671538 & 7.6144 & \begin{tabular}{ll|}
0.080471 \\
\end{tabular} & 0.1147 & 0.027321 & 0.4898 & $\begin{array}{ll}0.026881 \\
\end{array}$ & 22.51163 & 0.042414 & 230.42 & 0.91 & 15.09 & 0.12 \\
\hline 16 & 5646.1506 & 2.300193 & 250.6278 & 0.262752 & 3.1729 & 0.09575 & 0.0396 & 0.024067 & 0.1164 & 0.010823 & 22.564468 & 0.041462 & 230.93 & 0.91 & 6.14 & 0.00 \\
\hline 17 & 6067.335725 & 3.032971 & 269.90455 & 0.204594 & 3.283053 & 0.090692 & 0.086773 & 0.017922 & 0.106539 & 0.024578 & 22.536598 & 0.045029 & 230.66 & 0.93 & 6.62 & 0.00 \\
\hline 18 & 11208.91536 & 4.067303 & 498.61139 & 0.384155 & 6.309062 & 0.056299 & 0.111073 & 0.019973 & 0.228968 & 0.021664 & 22.518113 & 0.037956 & 230.48 & 0.90 & 12.22 & 0.00 \\
\hline 19 & \begin{tabular}{|l|l|}
8978.93048 \\
\end{tabular} & 2.812478 & 399.58086 & 0.49249 & 4.943116 & 0.108052 & 0.110953 & 0.022993 & 0.133868 & 0.020693 & 22.544966 & 0.04417 & 230.74 & 0.92 & 9.80 & 0.00 \\
\hline 20 & 11769.0414 & 4.790629 & 525.23379 & 0.523018 & 6.398585 & 0.092997 & 0.077086 & 0.019698 & 0.094042 & 0.020928 & 22.52542 & 0.040112 & 230.55 & 0.90 & 12.88 & 0.00 \\
\hline 21 & $\begin{array}{r}9954.057918 \\
\end{array}$ & 2.901399 & $\begin{array}{l}443.4035 \\
\end{array}$ & 0.372649 & \begin{tabular}{|l|l|}
5.379588 \\
\end{tabular} & 0.105757 & 0.066339 & 0.025932 & 0.0955 & 0.019273 & 22.557162 & 0.038156 & 230.86 & 0.90 & 10.87 & 0.00 \\
\hline fusion & 1658.631903 & 1.065643 & 73.622111 & 0.085527 & 0.893984 & 0.057892 & 0.007033 & 0.033031 & 0.033963 & 0.01424 & 22.565854 & 0.070536 & 230.94 & 1.06 & 1.80 & 0.00 \\
\hline
\end{tabular}




\begin{tabular}{|c|c|c|c|c|c|c|c|c|c|c|c|c|c|c|c|c|}
\hline & & & & & & & & & & & & & & & & \\
\hline & Title & Nb of steps & J parameter & $\pm \mathrm{J}$ & $\lambda\left(\mathrm{y}^{-1}\right)$ & $\pm \lambda\left(\mathrm{y}^{-1}\right)$ & Discrimination & \pm Discriminat & & & & & & & & \\
\hline & 12JK56 muscovite & 18 & \begin{tabular}{|l|}
$6.04 \mathrm{E}-03$ \\
\end{tabular} & $1.64 \mathrm{E}-05$ & $5.53 \mathrm{E}-10$ & 1.35E-12 & 1.005943 & \begin{tabular}{|l|}
$1.31 \mathrm{E}-03$ \\
\end{tabular} & & + & & & & & & \\
\hline Step & ${ }^{40} \mathrm{Ar}$ & $\pm^{40} \mathrm{Ar}$ & ${ }^{39} \mathrm{Ar}$ & $\pm{ }^{39} \mathrm{Ar}$ & ${ }^{38} \mathrm{Ar}$ & $\pm^{38} \mathrm{Ar}$ & ${ }^{37} \mathrm{Ar}$ & $\pm{ }^{37} \mathrm{Ar}$ & ${ }^{36} \mathrm{Ar}$ & $\pm^{36} \mathrm{Ar}$ & ${ }^{40} \mathrm{Ar}^{*} \beta^{39} \mathrm{Ar}_{\mathrm{K}}$ & $\pm{ }^{40} \mathrm{Ar}^{*} / \beta^{39} \mathrm{Ar}_{\mathrm{K}}$ & age (Ma) & \pm Age (Ma) & $\%{ }^{39} \mathrm{Ar}$ & Atm. Cont. \\
\hline 1 & 4347.980187 & 1.336916 & 36.336569 & 0.059271 & 0.563993 & 0.035568 & 0.044032 & 0.034821 & \begin{tabular}{|l}
0.277916 \\
\end{tabular} & 0.018855 & 118.034 & $\begin{array}{l}0.297887 \\
\end{array}$ & 972.95 & 3.67 & 1.82 & 1.27 \\
\hline 2 & 9891.788045 & 4.163374 & 51.467371 & 0.103959 & 0.623516 & 0.030765 & 0.052435 & 0.026112 & 0.084362 & 0.016244 & 192.70476 & 0.479984 & 1395.49 & 4.95 & 2.58 & 0.00 \\
\hline 3 & 65350.24608 & 69.450403 & 259.74283 & 0.366432 & 3.465309 & 0.065641 & 0.142825 & 0.030706 & 0.136105 & 0.017368 & 252.73664 & 0.55489 & 1675.56 & 5.59 & 13.02 & 0.00 \\
\hline 4 & 5791.794364 & 10.111665 & 24.195094 & 0.074361 & 0.338228 & 0.030097 & 0.027691 & 0.022868 & 0.02425 & 0.014318 & 240.31833 & 0.921752 & 1621.08 & 6.40 & 1.21 & 0.00 \\
\hline 5 & 21389.19798 & 9.452733 & 83.355485 & 0.117298 & 1.126536 & 0.046758 & 0.030572 & 0.020058 & 0.06735 & 0.015578 & 257.68471 & 0.5101 & 1696.82 & 5.56 & 4.18 & 0.00 \\
\hline 6 & 40342.43248 & 53.532806 & 150.12259 & 0.242577 & 1.870536 & 0.127554 & 0.104572 & 0.021625 & 0.06835 & 0.019119 & 269.97919 & 0.665895 & 1748.59 & 5.93 & 7.53 & 0.00 \\
\hline 7 & 76917.21293 & 62.523818 & 278.40541 & 0.349266 & 3.679938 & 0.046283 & 0.090586 & 0.037856 & 0.067918 & 0.030732 & 277.62549 & 0.550915 & 1780.05 & 5.78 & 13.96 & 0.00 \\
\hline 8 & 53568.82783 & 15.096987 & 201.44121 & 0.262921 & 2.580738 & 0.068821 & 0.099086 & 0.041887 & 0.086318 & 0.011344 & 267.16881 & 0.49831 & 1736.89 & 5.61 & 10.10 & 0.00 \\
\hline 9 & 44273.28833 & 44.939964 & 165.82591 & 0.389349 & 2.161538 & 0.067346 & 0.171586 & 0.035934 & 0.107518 & 0.015952 & 268.17028 & 0.770004 & 1741.07 & 6.13 & 8.31 & 0.00 \\
\hline 10 & 19227.80853 & 6.501632 & 72.888614 & 0.071219 & 0.958738 & 0.040629 & 0.126386 & 0.034993 & 0.073518 & 0.006503 & 264.86113 & 0.441696 & 1727.22 & 5.51 & 3.65 & 0.00 \\
\hline 11 & 36444.73031 & 41.522027 & 135.48463 & 0.291184 & 1.770007 & 0.037945 & 0.05127 & 0.04228 & 0.061688 & 0.014548 & 270.24369 & 0.745957 & 1749.69 & 6.09 & 6.79 & 0.00 \\
\hline 12 & 51121.92121 & 38.74685 & 186.18803 & 0.172527 & 2.304407 & 0.068894 & 0.05537 & 0.027263 & 0.047488 & 0.012789 & 275.90683 & 0.48808 & 1773.03 & 5.67 & 9.33 & 0.00 \\
\hline 13 & 27115.14751 & 30.50535 & 98.120132 & 0.195029 & 1.336207 & 0.020886 & 0.08317 & 0.022695 & 0.029488 & 0.016566 & 277.67948 & 0.731259 & 1780.28 & 6.10 & 4.92 & 0.00 \\
\hline 14 & $\begin{array}{l}9059.72761 \\
\end{array}$ & 8.407532 & 68.988032 & 0.134947 & 0.875207 & 0.042968 & 0.07437 & 0.023097 & 0.043188 & 0.013448 & 277.51385 & 0.665717 & 1779.60 & 5.98 & 3.46 & 0.00 \\
\hline 15 & 26530.33241 & 9.028445 & 95.143932 & 0.100817 & 1.157807 & 0.050539 & 0.07817 & 0.031807 & 0.065788 & 0.011834 & 280.07525 & 0.481214 & 1790.02 & 5.70 & 4.77 & 0.00 \\
\hline 16 & 8611.071446 & 8.064173 & 31.082739 & 0.066737 & 0.486251 & 0.041695 & 0.064363 & 0.029029 & 0.057712 & 0.017221 & 277.92175 & 0.763106 & 1781.26 & 6.17 & 1.56 & 0.00 \\
\hline 17 & $\begin{array}{l}3896.159157 \\
\end{array}$ & 2.244025 & 14.36344 & 0.04301 & 0.195062 & 0.021403 & 0.028266 & 0.023378 & 0.007598 & 0.016589 & 272.49878 & 0.964332 & 1759.02 & 6.61 & 0.72 & 0.00 \\
\hline fusion & 11819.29949 & 7.190231 & 41.528158 & 0.131525 & 0.61936 & 0.032678 & 0.041353 & 0.032944 & 0.083151 & 0.025758 & 285.4865 & 1.009644 & 1811.84 & 6.75 & 2.08 & 0.00 \\
\hline
\end{tabular}


Research highlights

- Large parts of Korea have been affected by a thermal pulse in the late Triassic

- This is manifest by magmatism, and metamorphism, and isotopc ages generally between 235-228 Ma

- Ar/Ar ages 231-228 Ma on a regional scale, in low- and high-grade rocks, and sediments are due to this event

- Ar/Ar ages point to very fast cooling $100-150^{\circ} \mathrm{C} / \mathrm{Ma}$, probably during core complex like exhumation

- This evolution maybe due to slab detachment/delamination 